\title{
Controle de infecções intramamárias no gado leiteiro usando as propriedades antibacterianas e cicatrizantes do muco de escargots Achatina sp no pré e pós dipping
}

Dissertação apresentada ao Programa de Pós - Graduação em Nutrição e Produção Animal da Faculdade de Medicina Veterinária e Zootecnia da Universidade de São Paulo para obtenção do título de Mestre em Ciências

Departamento:

Nutrição e Produção Animal

Área de Concentração:

Nutrição e Produção Animal

Orientador (a):

Profa. Dra. Maria de Fátima Martins

Pirassununga

2010 
Autorizo a reprodução parcial ou total desta obra, para fins acadêmicos, desde que citada a fonte.

DADOS INTERNACIONAIS DE CATALOGAÇÃO-NA-PUBLICAÇÃO

(Biblioteca Virginie Buff D’Ápice da Faculdade de Medicina Veterinária e Zootecnia da Universidade de São Paulo)

Yokoya, Eugênio

Controle de infecções intramamárias no gado leiteiro usando as propriedades antibacterianas e cicatrizantes do muco de escargots Achatina sp no pré e pós dipping / Eugênio Yokoya. -- 2010.

99 f. : il.

Dissertação (Mestrado) - Universidade de São Paulo. Faculdade de Medicina Veterinária e Zootecnia. Departamento de Nutrição e Produção Animal, Pirassununga, 2010.

Programa de Pós-Graduação: Nutrição e Produção Animal.

Área de concentração: Nutrição e Produção Animal.

Orientador: Profa. Dra. Maria de Fátima Martins.

1. Muco. 2. Escargot. 3. Mastite. 4. Pré e pós dipping. I. Título. 


\section{FACULDADE DE MEDICINA VETERINÁRIA E ZOOTECNIA} Comissão Bioética

\section{CERTIFICADO}

Certificamos que o Projeto intitulado "Controle de infecções intramamárias no gado leiteiro usando as propriedades antibacterianas e cicatrizantes do muco de escargot Achatina sp no pré e pos dipping", protocolado sob o n⿳1322/2008, utilizando 09 (nove) vacas, sob a responsabilidade da Profa. Dra. Maria de Fátima Martins, está de acordo com os princípios éticos de experimentação animal da Comissão de Bioética da Faculdade de Medicina Veterinária e Zootecnia da Universidade de São Paulo e foi aprovado na reunião do dia 23 de abril de 2008.

We certify that the Research "Infections intramammary control in dairy cattle using the antibacterial and healing properties of the snail mucus Achatina sp in the pre and pos dipping", utilizing 09 (nine) cows, protocol number 1322/2008, under the responsibility Profa. Dra. Maria de Fátima Martins, agree with Ethical Principles in Animal Research adopted by Bioethic Commission of the School of Veterinary Medicine and Animal Science of University of São Paulo and was approved in the meeting of day $04 / 23 / 08$.

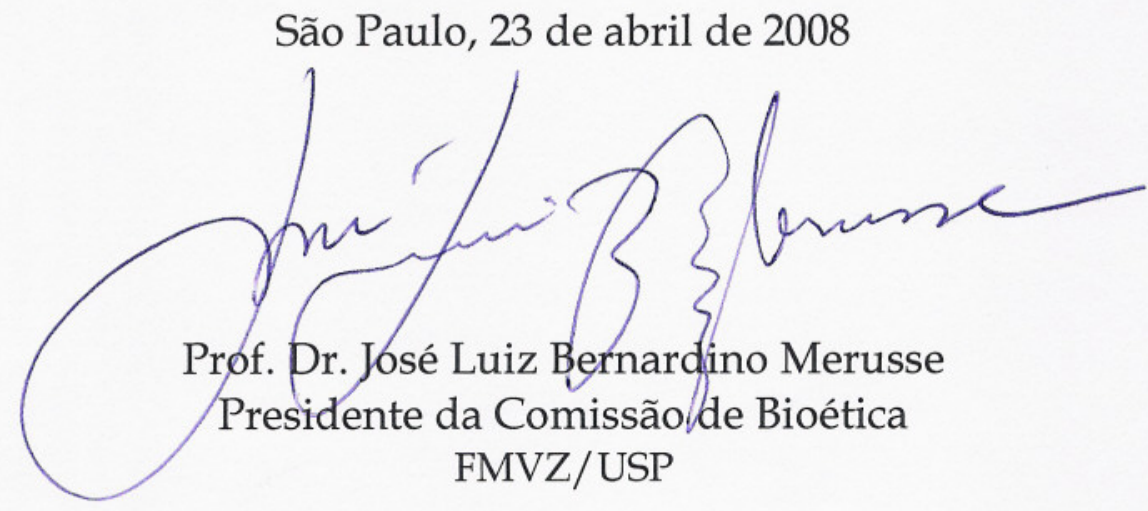


Nome: Yokoya, Eugênio

Título: Controle de infecções intramamárias no gado leiteiro usando as propriedades antibacterianas e cicatrizantes do muco de escargots Achatina sp no pré e pós dipping

Dissertação apresentada ao Programa de Pós - Graduação em Nutrição e Produção Animal da Faculdade de Medicina Veterinária e Zootecnia da Universidade de São Paulo para obtenção do título de Mestre em Ciências

Data:

\section{Banca Examinadora}

Prof. Dr. Instituição:

Assinatura: Julgamento:

Prof. Dr. Instituição:

Assinatura: Julgamento:

Prof. Dr. Instituição: Julgamento: 


\section{AGRADECIMENTOS}

À Deus por iluminar os meus caminhos e estar presente em todos os momentos, me ajudando seguir em frente com fé e perseverança.

À minha orientadora Profa ${ }^{\mathrm{a}}$ Dr ${ }^{\mathrm{a}}$. Maria de Fátima Martins pelo constante incentivo, interlocutora interessada em participar de minhas inquietações, coautora em vários trechos. Agradeço, principalmente, pela confiança depositada em mim.

A Profa Dra. Mamie Misusaki lyomasa e ao Prof. Dr. Rogério Lacaz por aceitarem participar da Banca.

A Cristina da Fundação "André Tosello" pela identificação das "minhas meninas".

A Helena pela grande participação na tese até a sua confecção.

Ao Zeca do Laboratório de Tecnologia Produtos de Origem Animal, pelo apoio e pelos materiais doados que ajudaram muito na confecção deste trabalho.

Ao pessoal do VNP: Juliana, Michele, Diogo, Elaine, Helena e a todos os colegas, pelo apoio durante todo o curso de Mestrado.

A Prof ${ }^{\mathrm{a}}$. Neusa que sempre me elogiou e nunca deixou de me apoiar.

Ao meu pai, Prof. Dr. Fumio Yokoya, que teve uma importante participação não só durante a realização desta tese, mas em todas as fases de minha vida, sempre indicando a direção a ser tomada nos momentos de maior dificuldade. 
A minha mãe, Toshie (in memoriam), apesar de não estar presente, sinto que está feliz por mais esta conquista.

A minha filha Ana Carolina, que muito me desculpou por meus atrasos, ou pela necessidade de ficar na casa de amigas para que eu pudesse apresentar trabalhos em congressos.

A minha irmã Patrícia, minha sobrinha Maria Julia, e ao meu cunhado Aislan por me apoiarem em todas as minhas decisões.

Ao meu sogro Kodhai, minha sogra Célia e meu cunhado Otávio, por acreditarem em minha capacidade e dedicação.

E... Especialmente à minha esposa, colega e amiga Carolina, por estar comigo nesta jornada e aos meus enteados Lucas e Daniel, e a toda minha família que sempre acreditaram na conclusão deste trabalho. 


\section{RESUMO}

YOKOYA, E. Controle de infecções intramamárias no gado leiteiro usando as propriedades antibacterianas e cicatrizantes do muco de escargots Achatina $s p$ no pré e pós dipping. [Control of intramammary infections in dairy cattle using antibacterial and healing properties of the mucus of snails Achatina $s p$ in pre and post dipping]. 2010. 99 f. Dissertação (Mestrado em Ciências) Faculdade de Medicina Veterinária e Zootecnia, Universidade de São Paulo, São Paulo, 2010.

O controle de mastite consiste em um conjunto de medidas de manejo e prevenção da doença em um rebanho, pois estudos realizados em todo estado de São Paulo estimaram um prejuízo de $17 \%$ da produção por propriedade devido à mastite considerando perdas como os gastos com tratamentos; descarte de leite; queda na produção; além de perdas por resíduos de antibióticos. O trabalho mostra que a população microbiana da mucosa dos tetos não varia conforme a sua posição no úbere do animal e a identificação dos microorganismos predominantes foram como sendo de Staphylococcus aureus, Micrococcus luteus, Klebsiella pneumoniae e Acinetobacter junii. O objetivo deste trabalho foi determinar a eficácia do muco de escargot nos tetos de vacas leiteiras utilizando-o como "pré e pós dipping" e o comparado com a aplicação de solução de iodo, visando à prevenção ou a redução da incidência de infecções intramamárias. O muco de escargot possui uma propriedade antibacteriana bastante efetiva, conhecida como Achacin. Sua ação bactericida ocorre principalmente na fase de crescimento da bactéria agindo como agente quimioterápico. O muco de escargot mostrou ser igualmente eficiente no controle da população de microorganismo presente na superfície dos tetos, quando comparados ao uso da solução de iodo, além de que o seu efeito sobre a pele e mucosa dos tetos foi de deixá-los mais hidratados e com melhor elasticidade evitando rachaduras e focos de infecção, quando comparado ao agente mineral, podendo ser até mesmo um produto alternativo no controle e prevenção de mastite em vacas leiteiras.

Palavras-chave: Muco, Escargot, Mastite, Pré e pós dipping 


\begin{abstract}
YOKOYA, E. Control of intramammary infections in dairy cattle using antibacterial and healing properties of the mucus of snails Achatina $s p$ in pre and post dipping [Controle de infecções intramamárias no gado leiteiro usando as propriedades antibacterianas e cicatrizantes do muco de escargots Achatina $s p$ no pré e pós dipping]. 2010. 99 f. Dissertação (Mestrado em Ciências) Faculdade de Medicina Veterinária e Zootecnia, Universidade de São Paulo, Pirassununga, 2010.
\end{abstract}

The control of mastitis is a set of measures for management and prevention of disease in a herd, because studies from every state of Sao Paulo have estimated a loss of $17 \%$ in a property considering losses due to mastitis as spending on treatments; discarded milk, drop in production, and losses due to antibiotic residues. The study shows that the microbial population of the mucosa of the teats doesn't vary according to their position in the animal's udder and identification of microorganisms were predominant as Staphylococcus aureus, Micrococcus luteus, Klebsiella pneumoniae and Acinetobacter junii. The objective of this study was to determine the effectiveness of snail mucus teats of dairy cows using it as a "pre and post dipping" and compared with the application of iodine solution, aiming at preventing or reducing the incidence of mammary infections. The mucus of snail has a very effective antibacterial property, known as Achacin. Its bactericidal action occurs mainly in the growth of bacteria by acting as a chemotherapeutic agent. The mucus of snail proved to be equally effective in controlling the population of microorganisms present on the surface of the teats, compared to the use of iodine solution, and that its effect on the skin and mucous membrane of the teats was leaving them more hydrated and with improved elasticity avoiding cracks and foci of infection, when compared to mineral agent, which may even be an alternative product in the control and prevention of mastitis in dairy cows.

Keyword: Mucus, Snail, Mastitis, Pre and post dipping. 


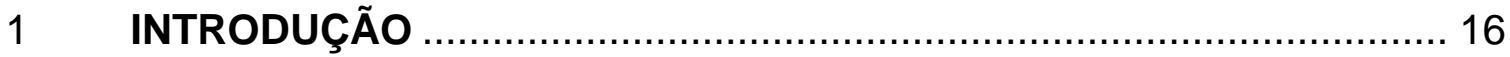

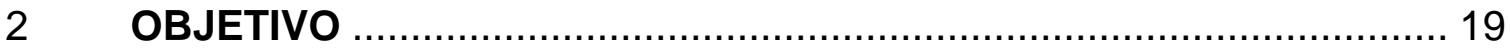

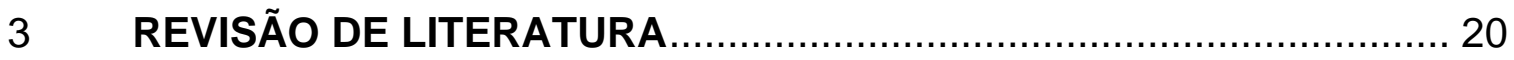

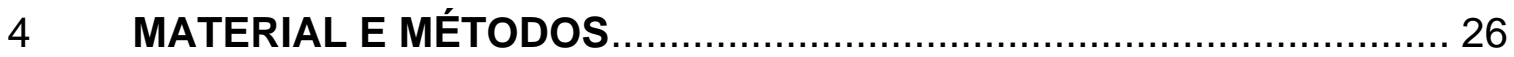

4.1 ATIVIDADES DESENVOLVIDAS NAS PROPRIEDADES .................... 26

4.1.1 Seleção genética e preparo dos escargots para coleta de

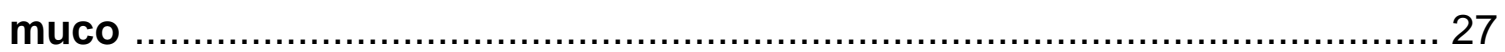

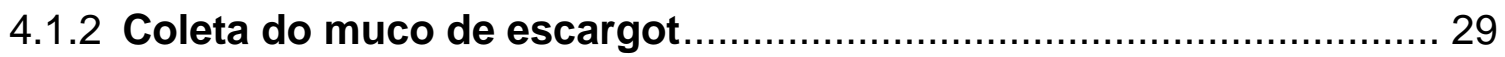

4.2 SELEÇÃO DAS PROPRIEDADES PARA COLETA DE AMOSTRA ................ 32

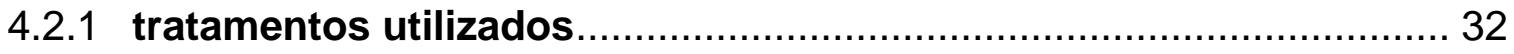

4.2.2 Preparo do teto da vaca em pré dipping ……................................ 33

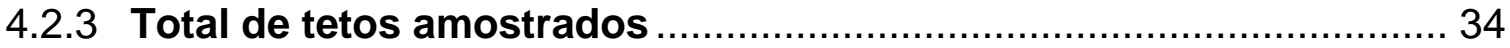

4.2.4 Preparo do teto da vaca em Pós dipping ………........................... 35

4.2.5 Estimativa da densidade de microorganismo.................................. 36

4.2.6 Verificação de mastite nos animais ............................................... 37

4.2.7 Avaliação dos grupos de microorganismos ..................................... 38

4.3 VERIFICAÇÃO DA POSIÇÃO DOS TETOS EM RELAÇÃO À CONTAGEM MICROBIANA ................................................................ 40

4.4 ISOLAMENTO DAS COLÔNIAS DAS PLACAS MÉTODOS DE COLORAÇÃO DE GRAM, CATALASE E MORFOLOGIA ....................... 40

4.5 IDENTIFICAÇÃO BIOQUÍMICA E FISIOLÓGICA DAS

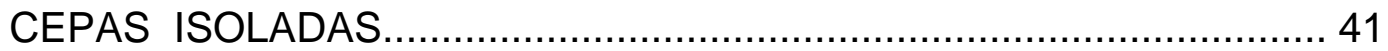

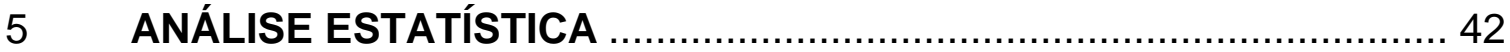

5.1 COMPARATIVO ENTRE TRATAMENTO COM SOLUÇÃO DE IODO E MUCO DE ESCARGOT ACHATINA FULICA 
5.2 COMPARATIVO ENTRE TRATAMENTOCOM

SOLUÇÃO DE IODO E MUCO DE ESCARGOT ACHATINA

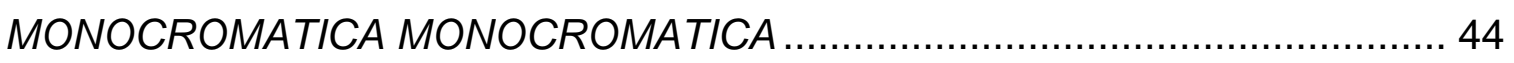

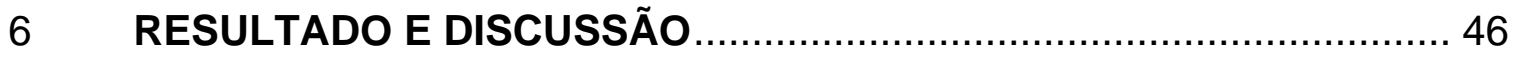

6.1 EFEITO DA POSIÇÃO DOS TETOS NA CONTAGEM

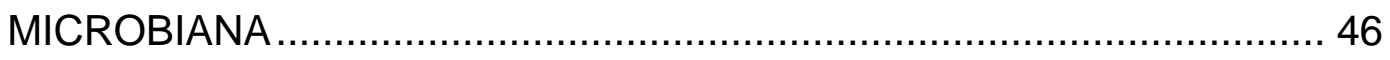

6.2 EFEITOS DOS DIFERENTES TRATAMENTOS DOS TETOS ............... 49

6.3 IDENTIFICAÇÃO PRELIMINAR DOS MICROORGANISMOS

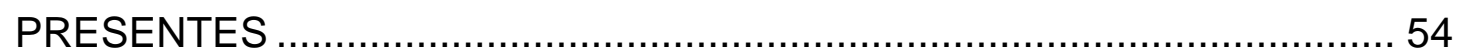

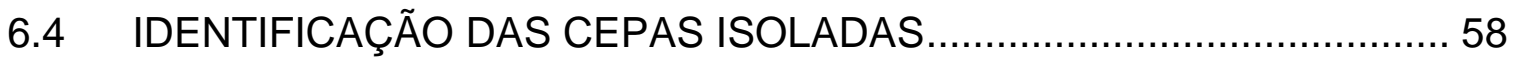

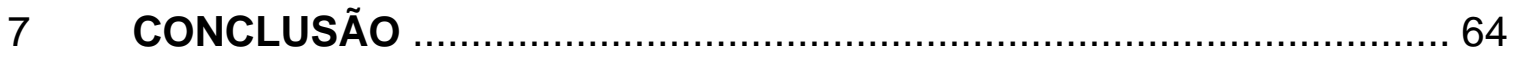

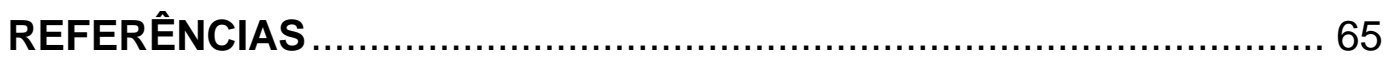

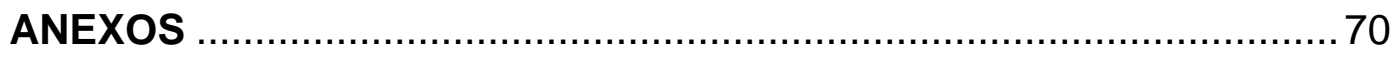




\section{LISTA DE TABELAS}

Tabela 1 - Teste F duas amostras para variâncias (solução de iodo, 200ppm (Si) e muco de escargot Achatina fulica $(A F))$

Tabela 2 - Teste T: duas amostras presumindo variâncias equivalentes (solução de iodo, 200ppm (Si) e muco de escargot Achatina fulica $(\mathrm{AF}))$. .44

Tabela 3 - Teste F duas amostras para variâncias (solução de iodo, 200ppm (Si) e muco de escargot Achatina monocromatica. monocromatica $(\mathrm{AM}))$

Tabela 4 - Teste T duas amostras para variâncias (solução de iodo, 200ppm (Si) e muco de escargot Achatina monocromatica. monocromatica $(\mathrm{AM}))$

Tabela 5 - Avaliação das posições dos tetos na contagem de microorganismos do grupo Staphylococcus-micrococcus (Baird Parker).

Tabela 6 - Avaliação das posições dos tetos na contagem de microorganismos total (Plate Count Agar).

Tabela 7 - Estimativa dos diferentes grupos de microorganismos presentes nas tetas de vacas após tratamento com solução de iodo (200 ppm), muco de escargot Achatina fulica (AF), muco de escargot Achatina monocromatica monocromatica (AM), e controle (sem tratamento). Dados da propriedade A 
Tabela 8 - Estimativa dos diferentes grupos de microorganismos presentes nas tetas de vacas após tratamento com solução de iodo (200 ppm), muco de escargot Achatina fulica (AF), muco de escargot Achatina monocromatica monocromatica (AM), e controle (sem tratamento). Dados da propriedade B.

Tabela 9 - Estimativa dos diferentes grupos de microorganismos presentes nas tetas de vacas após tratamento com solução de iodo (200 ppm), muco de escargot Achatina fulica (AF), muco de escargot Achatina monocromatica monocromatica (AM), e controle (sem tratamento). Dados da propriedade C.

Tabela 10 - Somatória dos valores atribuídos às contagens de todos os microorganismos das três propriedades

Tabela 11 - Características Morfológicas, Catalase e de Coloração de Gram de Colônias Isoladas do Meio de Contagem Total. .53

Tabela 12 - Características Morfológicas, Catalase e de Coloração de Gram de Colônias Isoladas do Meio de Staphylococus-micrococcus (Baird Parker). .54

Tabela 13 - Características Morfológicas, Catalase e de Coloração de Gram de Colônias Isoladas do Meio de Coliformes. 55

Tabela 14 - Características Morfológicas, Catalase e de Coloração de Gram de Colônias Isoladas do Meio de Saboraund (fungos, bolores e algas). .56

Tabela 15 - Resultado da identificação, fisiologia, e bioquímica das oito cepas isoladas de diferentes meios usadas no isolamento.

Tabela 16 - Principais agentes causadores de mastite em vacas leiteiras 60 


\section{LISTA DE FIGURAS}

Figura 1 - Mensurações para seleção do escargot no experimento .29

Figura 2 - Biometria da concha de escargot africano 30

Figura 3 - Caixas para criação do escargot Achatina fulica. 31

Figura 4-Técnica de retirada do muco através da estimulação da glândula podal. 32

Figura 5 - Muco de escargot Achatina fulica, após a retirada do animal .32

Figura 6 - Muco de escargot Achatina fulica liofilizado .33

Figura 7 - Liofilizador marca Terroni®. .33

Figura 8 - Escargot da espécie Achatina monocromatica monocromatica, morto por causa desconhecida .34

Figura 9 - Preparação do animal para a ordenha 35

Figura 10 - Animal recebendo tratamento de pós- dipping durante a ordenha 35

Figura 11 - Forma de aplicação dos produtos antisépticos (solução de iodo, muco de escargot Achatina fulica e Achatina monocromática monocromatica) 
Figura 12- Forma de amostragem com auxilio do "swab"

Figura 13- Amostra de swab em tubo de ensaio com solução salina 0,9\%forma de amostragem com auxilio do "swab"

Figura 14 -Método de esgotamento para identificação semi-quantitativa de bactérias. ( $1^{\mathrm{a}}$ aplicação da amostra; $2^{\mathrm{a}}$ espalhamento da $1^{\mathrm{a}}$ estria; $3^{\mathrm{a}}$ espalhamento da $2^{\mathrm{a}}$ estria)

Figura 15 - Semeadura em placas de Petri contendo meio de cultura 40

Figura 16 - Representação esquemática da metodologia utilizada para o isolamento de microorganismos 


\section{INTRODUÇÃO}

Nos Estados Unidos, o custo com a prevenção da mastite pode chegar em média em torno de U\$23,98/vaca/ano, mas perdas por mastite sub-clínica podem alcançar um índice ainda maior, sendo considerada em média um custo de U\$317,38/vaca/ano. No Brasil, o estudo econômico da mastite ainda é bastante precário e necessita de mais dados para se obter uma estimativa confiável de sua grandeza. No estado de São Paulo, cuja produção gira em torno de 28.000 litros/mês/ propriedade, tem-se uma perda de aproximadamente 4.800 litros /mês/propriedade (COSTA, 1998). Esse prejuízo pode ser ainda maior quando se incluem propriedades menores cuja produção destina-se a venda de leite e seus derivados de forma pouco controlada ou mesmo clandestina, ou para consumo dentro de propriedades.

O método convencional do controle da mastite durante a ordenha consiste fundamentalmente da assepsia dos tetos após a lavagem com água, empregando produtos químicos de ação antimicrobiana a base de cloro, iodo ou quaternário de amônio. Algumas limitações podem ser citadas quanto ao uso desses agentes, tais como; possível efeito residual no leite e no animal, a não seletividade da sua ação sobre os patógenos e os saprófitos e o efeito colateral sobre a pele e mucosa dos tetos, como a desidratação da pele pelos produtos a base de iodo.

A produção de muco pelo escargot terrestre Achatina sp é estocada intracelularmente em vesículas demarcadas por membranas, e estas são secretadas na superfície corporal e membranas das mucosas. Este muco é composto de água, eletrólitos, glicoproteinas, mucosas e mucopolissacarídeos, lectinas e hemocianina (IGUCHI et al., 1985).

Pesquisadores japoneses descobriram um fator antimicrobiano no muco de escargot Achatina fulica (KUBOTA et al., 1985) com atividade contra as bactérias tanto Gram positiva quanto Gram negativa. Isto explica como estes animais se protegem contra as infecções causadas por microorganismos, apesar de apresentarem a pele bastante úmida e frágil. Esta toxicidade sobre bactérias, que é maior sobre as células na fase de crescimento do que em repouso, sugere que o muco pode ser um agente 
quimioterápico bastante funcional, por ser mais efetivo contra os patógenos que estão em fase de desenvolvimento ativo, do que contra as células do hospedeiro ou da flora normal, apresentando atividade de crescimento mais lento, e parte desta atividade antimicrobiana foi confirmada por Martins et al. (2003) em ratos infectados por bactérias Gram positivas e Gram negativas, além deste muco ter papel importante na locomoção, alimentação, regulação osmótica, reprodução, proteção epitelial e de certa superfície corporal exposta ao invés de dentro de cavidades corporais ou sob proteção de conchas.

O presente trabalho visou comparar a eficácia do muco de duas espécies de escargot (Achatina fulica e Achatina monocromatica monocromatica) no controle de microorganismos de superfície de tetos das vacas com o processo de desinfecção por uso de solução de iodo. O muco foi aplicado no tratamento pré e pós dipping dos tetos durante a ordenha. Para facilitar a detecção de microorganismos predominantes foi utilizado o método de esgotamento adotado por Spenber (2001) para avaliação dos contaminantes em amostras de alimentos.

Neste contexto, o estudo do efeito do muco de escargot Achatina $s p$ no pré e pós dipping poderá contribuir com as condutas e tratamentos utilizados na mastite bovina, através do controle de microorganismos na superfície dos tetos das vacas leiteiras em lactação.

Epidemiologicamente, a mastite bovina compreende em mastite contagiosa e ambiental. A terapia com antibiótico é a primeira opção de tratamento utilizada para combater a mastite, por via sistêmica ou intramamária, e sua eficácia irá depender da capacidade do medicamento atingir os locais da infecção e manter uma concentração mínima por um período suficiente para eliminar os microorganismos (BLOWEY e EDMONDSON, 1999).

Costa (1998) relata que os processos inflamatórios da glândula mamária exercem influencia sobre a farmacocinética e farmacodinâmica do medicamento de uso intramamário utilizados na terapia da mastite. 
O processo inflamatório associado ou não a práticas de antibióticoterapia inadequadas, aumentando o risco da presença de resíduos de antibiótico no leite.

A presença de resíduos antimicrobianos no leite representa um problema de saúde publica, principalmente por participar da seleção de bactérias resistentes aos antimicroorganismos. Pode também, ser considerado, um problema econômico, pois interfere nos processos de produção de leite (BRITO, 2001; BRITO et Al., 2000).

Faz-se necessária a busca de estudos e informações que contribuam com os envolvidos na cadeia de produção do leite, de forma que possa garantir um produto livre de resíduos de antibióticos e drogas.

Os estudos relativos ao uso de muco de escargots Achatina $s p$, são inéditos no Brasil e no mundo, e estão apenas no inicio, sendo esta uma área com potencial e necessidade de pesquisa, e profissionais capacitados para repassar seus conhecimentos aos produtores, e conseqüentemente expandir o uso desse biofármaco.

Estudos com a utilização do muco de escargots no pré e pós dipping apresentaram o mesmo efeito quando comparados com os tratamentos convencionais, porém a utilização do mesmo melhorou a textura dos tetos tratados. Com isso o estudo do muco de escargot, poderá acrescentar informações que contribuirão para o desenvolvimento de um biofármaco à base do muco de escargot para ser utilizado nos rebanhos leiteiros bovinos na prevenção da mastite. 


\section{OBJETIVO}

O principal objetivo deste trabalho consistiu em determinar a eficácia do muco de escargot nos tetos, quando aplicado como pré e "pós-dipping" visando à prevenção ou a redução da incidência de infecções intramamárias, haja visto que a maioria delas é causada por bactérias Gram positivas e Gram negativas.

O tratamento proposto nesta pesquisa foi comparar a aplicação de iodo tópico no pré e "pós-dipping", que é o método mais utilizado na pecuária leiteira dos tetos de vacas leiteiras em lactação com o muco de escargot liofilizado. 


\section{REVISÃO DE LITERATURA}

Estudo realizado dentro do Estado de São Paulo considerou a produção média em torno de 28.000 litros/mês /propriedade e uma estimativa de prejuízo devido à mastite sub-clínica, em média de 4.800 litros/mês/propriedade (17\% da produção por propriedade), considerando os gastos com tratamento, descarte de leite e queda na produção e principalmente por resíduos de antibióticos resultantes de tratamentos, sendo representado principalmente pela perda na produção de leite $(65 \%)$, leite descartado (15\%), custo de reposição (10\%), custos do medicamento (5\%), gastos com veterinário (3\%) e trabalho adicional (2 \%) (DOMINGUES e LANGONI, 2001).

O controle de mastite consiste em um conjunto de medidas de manejo para a prevenção da introdução de agentes causadores da doença de um rebanho ou até mesmo para redução na disseminação destes patógenos entre os animais, sendo que a compra de vacas leiteiras pode resultar em sérios riscos através da introdução de doenças infecto-contagiosas no rebanho leiteiro. Sendo assim medidas de biossegurança devem ser adotadas durante a compra destes animais (SANTOS, 2003).

A utilização de testes de detecção de mastite como o CMT (California Mastit Test) vem sendo bastante empregado no controle da mastite, mas alterações fisiológicas que ocorrem no início e fim da lactação podem interferir na interpretação dos resultados, surgindo assim alternativas na detecção da mastite como o CEL (Condutividade Elétrica do Leite), obtendo assim resultados mais confiáveis (JÚNIOR et al., 2006)

Langoni (2007) evidenciaram a múltipla etiologia microbiana das mastites utilizando 7.902 amostras de leite provenientes de tetos com infecções subclinicas e 850 casos clínicos. Observaram que os microorganismos mais freqüentes foram Staphylococcus spp., Streptococcus spp. e Corynebacterium spp. em ambas as enfermidades. Além disso, foram encontrados agentes fúngicos e alga aclorofilada (Prototheca zopfii) na sua etiologia, em 1997 pelo mesmo autor, utilizando 8.752 amostras de leite afetado por mastite clinica e subclinica. $\mathrm{Na}$ mastite ambiental, a complexidade etiológica é maior que a contagiosa, pois o agente pode 
sobreviver e se multiplicar no meio ambiente da vaca, principalmente em locais como a cama, água e solo, ocorrendo sua transmissão principalmente nos intervalos entre as ordenhas. Os principais microorganismos envolvidos são: Escherichia coli e outras enterobactérias, Pseudomonas aeruginosa, Nocardia spp. e Streptococcus uberis.

Durante o período que o animal não se encontra em produção (período seco), ocorre um maior índice de transmissão de agentes patogênicos para a glândula mamária (CARNEIRO, 2006).

Vansil e Venglovsky (1997) mostraram que os métodos preventivos e o uso de antibióticos para tratamento de animais reduziu o índice de mastite causado por bactérias de 47,3 para $1,9 \%$ em um período de aproximadamente 19 meses.

A utilização do pós-dipping está diretamente relacionada ao controle da mastite contagiosa, especialmente causadas por Staphylococcus aureus e Streptococcus agalactie enquanto o pré dipping é uma medida importante na melhoria da qualidade do leite e redução da Contagem de Células Somáticas do rebanho (SANTOS e FONSECA, 2007).

O maior contágio de mastite patogênica causada por Staphylococcus aureus e Streptococcus agalactiae podem ser controlada através da utilização de pós-dipping, mas não para a mastite ambiental causada por Streptococcus esculina positiva e bactérias do gênero Coliformes, entretanto, outras praticas de higiene na ordenha são importantes para redução da população bacteriana nos tetos (GALTON et al., 1988).

As utilizações de antisépticos adequados durante a ordenha podem reduzir novas infeç̧ões em 50 a $90 \%$, e a utilização de iodo a $2 \%$ e a $1 \%$ apresentou melhor desempenho in vitro, mas nesta concentração pode ser encontrado resíduo de iodo no leite, e o hipoclorito a $2 \%$ apresentou um ótimo desempenho, mas nesta concentração causava muita irritação na pele do teto dos animais (PEDRINI et al., 2003).

Os métodos alternativos de tratamento e prevenção contra mastite vêm sendo amplamente estudados nos últimos anos (ALMEIDA e BENITES, 2004). Os tratamentos homeopáticos (POZETTI, 1988) ainda são relativamente pouco difundidos se comparados aos tratamentos convencionais realizados (VANNIER e POIRIER, 19987). Porém, este 
quadro deve ser alterado com a popularização que vem ocorrendo gradualmente, principalmente depois que o Ministério da Saúde passou a considerar o uso de fitoterapia, homeopatia, acupuntura, termalismo e outras terapias alternativas nas unidades do Sistema Único de Saúde (SUS), através da Política Nacional de Práticas Integrativas e Complementares do SUS, sendo que na medicina veterinária apesar de não ser tão difundida como na medicina humana, autores como Almeida (2004) vem fazendo uso desta pratica terapêutica (homeopatia) na pecuária leiteira e em animais de companhia, o que nos motivou a pesquisar e aprofundar conhecimentos sobre as propriedades antibacterianas e cicatrizantes, como uma possível alternativa profilática no controle de mastites.

A partir de excreções, secreções, tecidos e órgãos de animais e vegetais, fisiológicos ou patológicos ou ainda microorganismos, podem ser preparados bioterápicos ou nosódios e aplicados com aspectos preventivos, uma vez que poderá utilizar o agente etiológico de determinada doença, sendo que a homeopatia não atua em agentes microbianos em particular, mas sim em indivíduos como um todo, de forma que os reflexos do desequilíbrio apresentado como doença, se processem em todo o organismo, podendo as reações ser variadas conforme a biologia dos indivíduos (ALMEIDA et al., 1999).

Aplicação semanais ou quinzenais de vacinas com bacterina de Staphylococcus aureus isolados do próprio rebanho tem sido empregado como alternativa no controle da mastite, mostrando certa eficiência no controle da mastite contagiosa, sendo que não substitui o bom manejo do rebanho, pois não impede totalmente a ocorrência da doença (ALBERTON et al., 2001).

Estudos utilizando barreiras à base de iodine, glicerina e polietileno glicol para proteção para entrada de microorganismos nos tetos de vacas leiteiras têm mostrado certa eficiência no controle da mastite (FORRET et al.,2006).

Os caracóis terrestres são gastrópodes pulmonares, pertencentes ao filo Mollusca possuindo uma concha espiralada, cabeça distinta com tentáculos, olhos e pé desenvolvido além de massa visceral com giro de $180^{\circ}$. Os moluscos terrestres apresentam um corpo que é bilateralmente assimétrico, tem vários centímetros de comprimento possuindo uma concha espiralada. $A$ 
superfície ventral do corpo é achatada e muscular formando uma sola rastejante ou pé. A superfície dorsal é coberta por uma concha espiral, convexa, que protege os órgãos internos ou massa visceral. A epiderme subjacente secreta a concha do animal, e a secreção mais ativa ocorrem ao redor da borda do manto, embora um pouco de material novo seja acrescentado às porções mais velhas da concha (RUPPERT e BARNES, 1996; GALO, 1984; SIMKISS e WILBUR, 1977).

O escargot terrestre Achatina fulica possui no muco uma ação antibacteriana bastante efetiva, atingindo as bactérias, tanto Gram-positivas quanto Gramnegativas (IGUCHI et al., 1982; MARTINS et al., 2003). Esta propriedade se deve principalmente a um fator antimicrobiano de peso molecular bastante elevado, sendo próximo a 160.000 na filtração em gel e entre 70.000 e 80.000 na eletroforese em gel de SDS-poliacrilamida (KUBOTA et al., 1985).

A lectina, sintetizada em amebócitos de escargot Achatina fulica, apresentou efeito bacteriostático em bactérias Gram-negativas Escherichia Coli, DH5a e C600 (BISWAS et al., 2000).

Dharmu et al. (2007) descobriu um efeito marcante de citotoxicidade da hemolinfa derivada de achatinin $_{H}$ (lectina) de Achatina fulica em células de carcinoma mamário humano (MCF7) .

No caso de outro molusco da espécie Arion ater possui como principal componente em seu muco uma cadeia longa de glicosaminoglicana e contém quantidade significativa de galactosamina, acido idurônico e galactose (COTTREL et al., 1994).

Fuchino et al. (1992) relataram que os fatores de defesa dos moluscos são principalmente as reações de defesa celular, na qual envolvem fagocitose e envolvimento de partículas estranhas; e os de fator de defesa hormonal, que envolve lisozimas, lecitinas, fatores antibacterianos ou antivirais e opsonização. Estes autores ainda relatam quanto a presença de uma glicoproteina chamada de "Achacin".

A purificação desta glicoproteina antibacteriana denominada de Achacin é secretada independente de o animal sofrer ou não algum tipo de estimulo ou injúria. O Achacin reconhece e se liga preferencialmente a bactérias em fase de crescimento, podendo ser útil e muito funcional como agente quimioterápico, pois é mais ativo contra o patógeno em proliferação do que 
para células do hospedeiro ou contra a flora normal, cuja característica é de crescimento mais lento (EHARA et al., 2002).

Essa glicoproteína, encontrada no muco de escargot Achatina fulica e também produzida pela levedura metilotrófica Pichia pastoris, possui uma ação bactericida de largo espectro, o que ocorre com Achacin recombinante (rAch) que, quando em concentrações da ordem de $100 \mu \mathrm{g} / \mathrm{ml}$, inibe o crescimento de bactérias como Pseudomonas fluorescens, Staphylococcus epidermidis e Streptococcus faecalis, além de E. coli e S. aureus, mas não foi visto a ação sobre o crescimento de Proteus mirabilis, Bacillus cereus e Micrococcus luteus (OGAWA et al., 1999).

Essa substância mucoglicoproteica produzida pelo escargot Achatina sp é composta por uma mistura de materiais provenientes de diversas glândulas, tendo como característica ser um fluido viscoelástico resultante da mistura da secreção de várias glândulas - que possui diversas funções, como veículo de transporte de partículas da superfície ciliada, secreção de produtos, transferência de água e eletrólitos através da epiderme e auxílio na locomoção (LORENZI et al., 2008).

Outra finalidade descrita sobre esta secreção para o animal é a de proteção do corpo contra desidratação, e para sua locomoção (SIRIO, 2005 e GOMOT, 1997).

Trabalhos mais recentes têm apresentado um novo glicosaminoglicano denominado "Acharan Sulfato" denominado de GAG tendo como estrutura 4 -2- acetomida- 2-deoxi- $\alpha$ - D- glucopiranose $(1 \rightarrow 4)$ - 2sulfo- $\alpha$ - L acido idopiranosiluronico, isolado do muco da espécie de escargot Achatina fulica, sendo que esta representa $3,5 \%$ de liquido do tecido corpóreo do escargot (JEONG et al, 2001), mas é nitidamente diferente de todos os membros conhecidos destas classes de glicosaminoglicanos, tendo como característica uma ação antitumoral, inibindo o seu crescimento, pois atua na maturação e na atividade funcional das células dendríticas. (KIM et al., 2007).

Segundo Fuchino et al. (1992), esse composto possui uma ação semelhante àquela de antibióticos pertencentes ao grupo beta-lactâmicos, que inibem a síntese de peptideoglicano na superfície celular, mas apesar da massa molecular relativamente alta comparada com a da penicilina ou da 
Sarcotoxina II-A (que possui peso molecular de 334), esta consegue atravessar o invólucro da membrana celular.

Programas de controle à mastite tendem a diminuir a prevalência da doença a níveis aceitáveis, uma vez que sua erradicação é inviável tanto financeiramente como na própria criação. Entre as medidas recomendadas para seu controle, incluem-se medidas higiênicas, entretanto, não sendo tão eficazes contra infecções intramamárias produzidas por microorganismos de origem ambiental ou oportunista (RANGEL, 2007).

Pedrini et al. (2003), descreve que o desenvolvimento de programas no controle da mastite implica em medidas como, tratamento de vacas no período seco, tratamento dos casos clínicos manejo adequado e bom funcionamento do sistema de ordenha.

Medidas como a lavagem dos tetos com água corrente e secagem com papel toalha reduzem o número de bactérias na superfície dos tetos, mas tornou-se mais eficiente com a utilização de antisépticos (iodo ou toalha com clorexidina), principalmente em casos que se utiliza o bezerro para a descida do leite durante a ordenha (BRITO et al., 2000). 


\section{MATERIAL E MÉTODOS}

Para a realização desta pesquisa foram utilizados os materiais e métodos descritos nos itens abaixo

\subsection{ATIVIDADES DESENVOLVIDAS NAS PROPRIEDADES}

A partir do mês de novembro de 2008 teve início a coleta das amostras, e foi realizado um questionário para avaliação do tipo de criação dos animais das propriedades (Anexo A) As vacas leiteiras das propriedades estudadas foram selecionadas de acordo com a presença ou ausência de mastite, conformação geral da glândula mamária, raça de aptidão leiteira, uso ou não de antibiótico, produção leiteira e realização ou não de pré e pós dipping (Figuras 1 e 2)

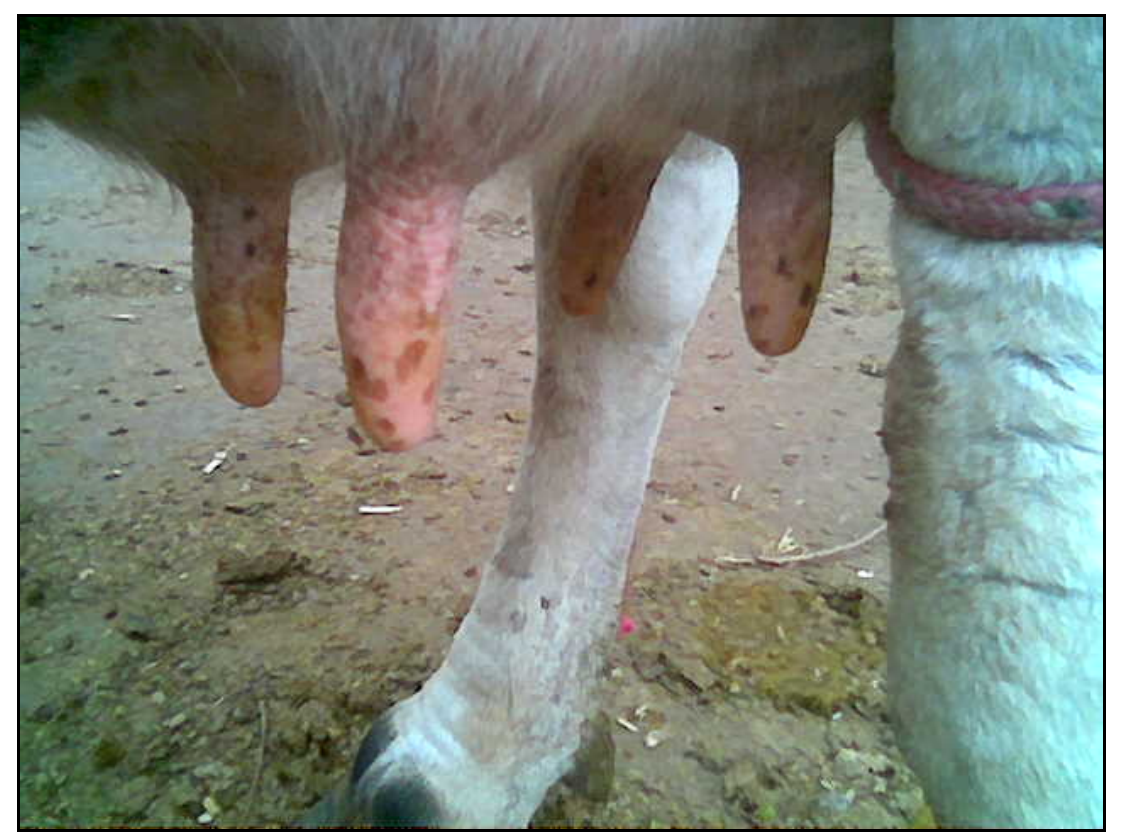

Figura 1: Preparação do animal para a ordenha 


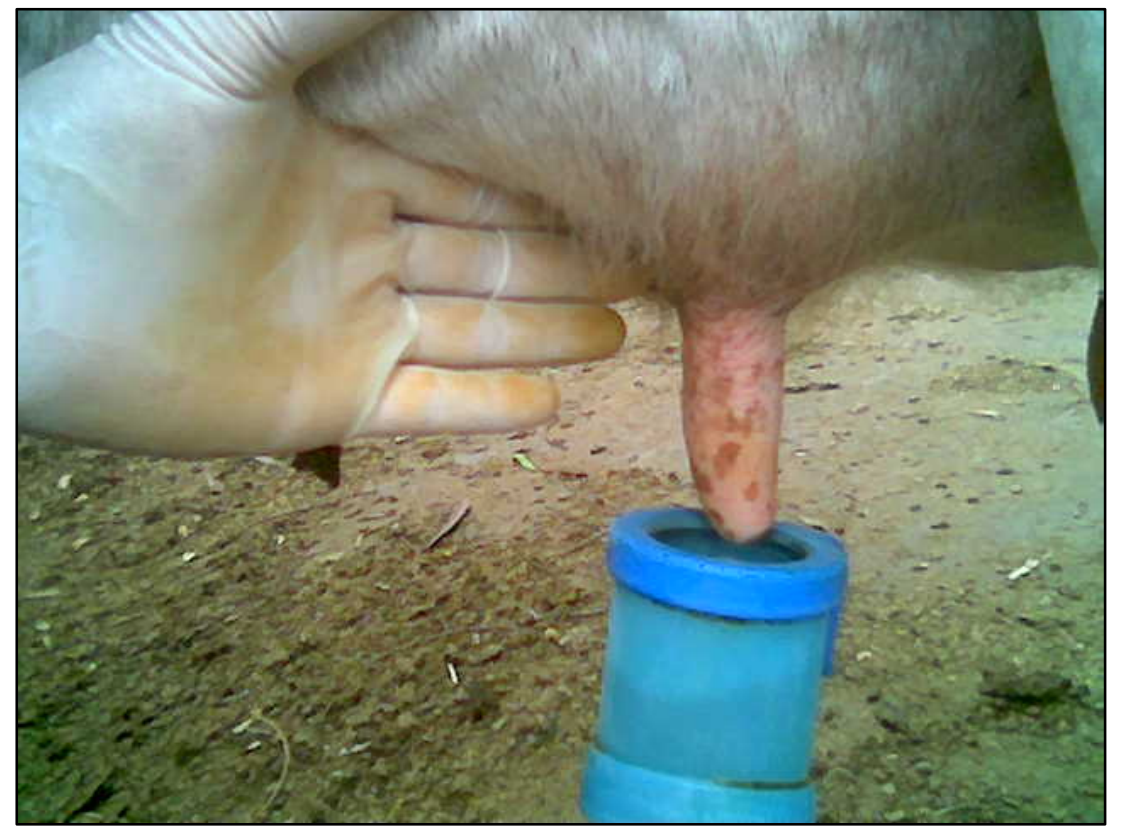

Figura 2: Animal recebendo tratamento de pós dipping durante a ordenha

\subsubsection{Seleção genética e preparo dos escargots para coleta de muco}

A massa corpórea e a avaliação do programa de seleção foram realizados através da pesagem dos animais e, com auxilio de um paquímetro foram mensurados o comprimento (medido do ápice à margem anterior da concha) e a largura (no ponto médio da concha), sendo utilizados animais com peso médio entre 120 a 180 gramas, para a coleta do muco (Figuras 3 e 4).

Os animais usados na coleta de muco foram separados e mantidos em caixas de madeira medindo $65 \mathrm{~cm}$ de altura por $40 \mathrm{~cm}$ de largura e $30 \mathrm{~cm}$ de altura. A densidade populacional foi de 10 animais por caixa. 


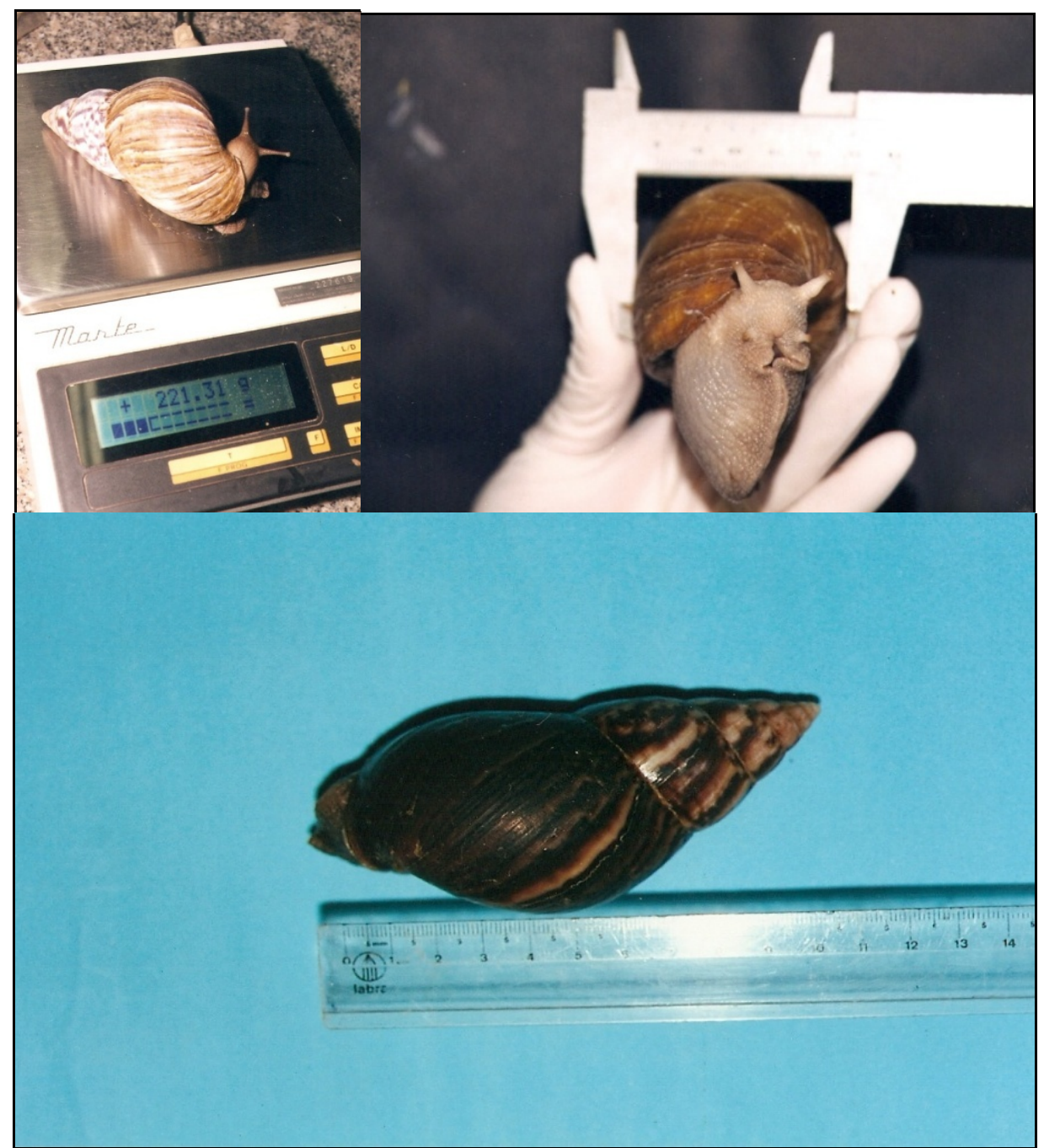

Figura 3: Mensurações para seleção do escargot para a utilização da pesquisa

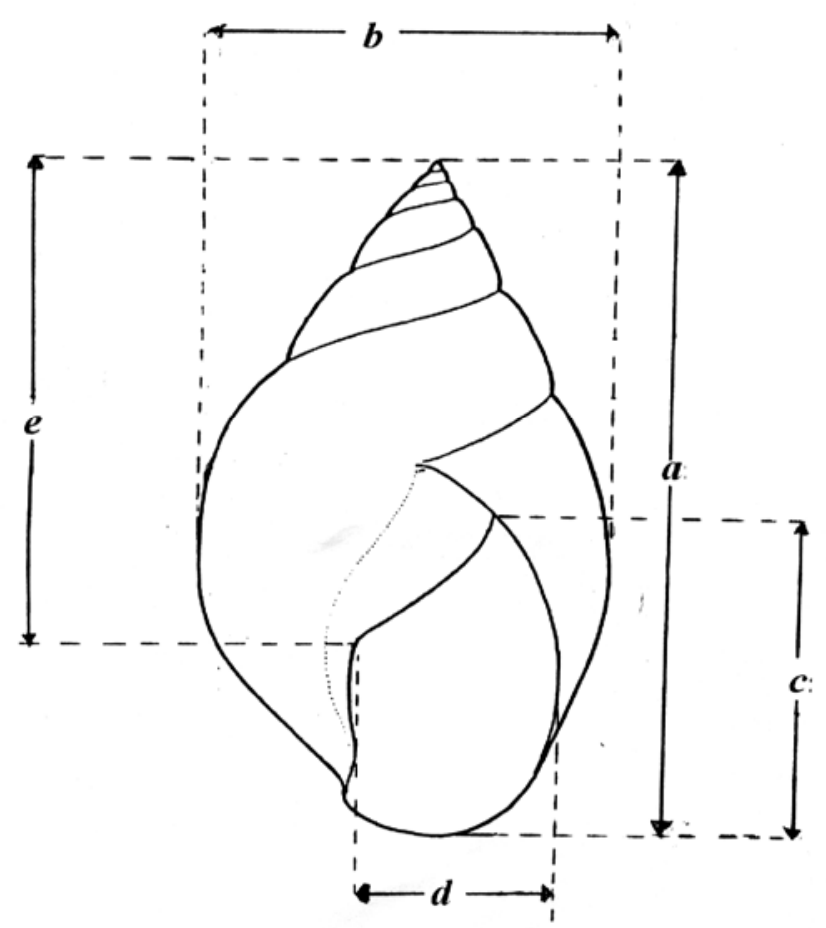

Figura 4: Biometria da concha de escargot africano, onde a é o comprimento, $b$ é o diâmetro ou largura, $c$ é a altura da abertura, $d$ é o diâmetro ou largura da abertura, e e é a altura da columela 
Os animais foram alimentados a cada dois dias com ração base desenvolvida a partir dos trabalhos de Pacheco et al. (1999), no Heliciário Experimental Prof ${ }^{a}$. Dra ${ }^{a}$ Lor Cury, da Faculdade de Medicina Veterinária e Zootecnia da Universidade de São Paulo (Figura 5).

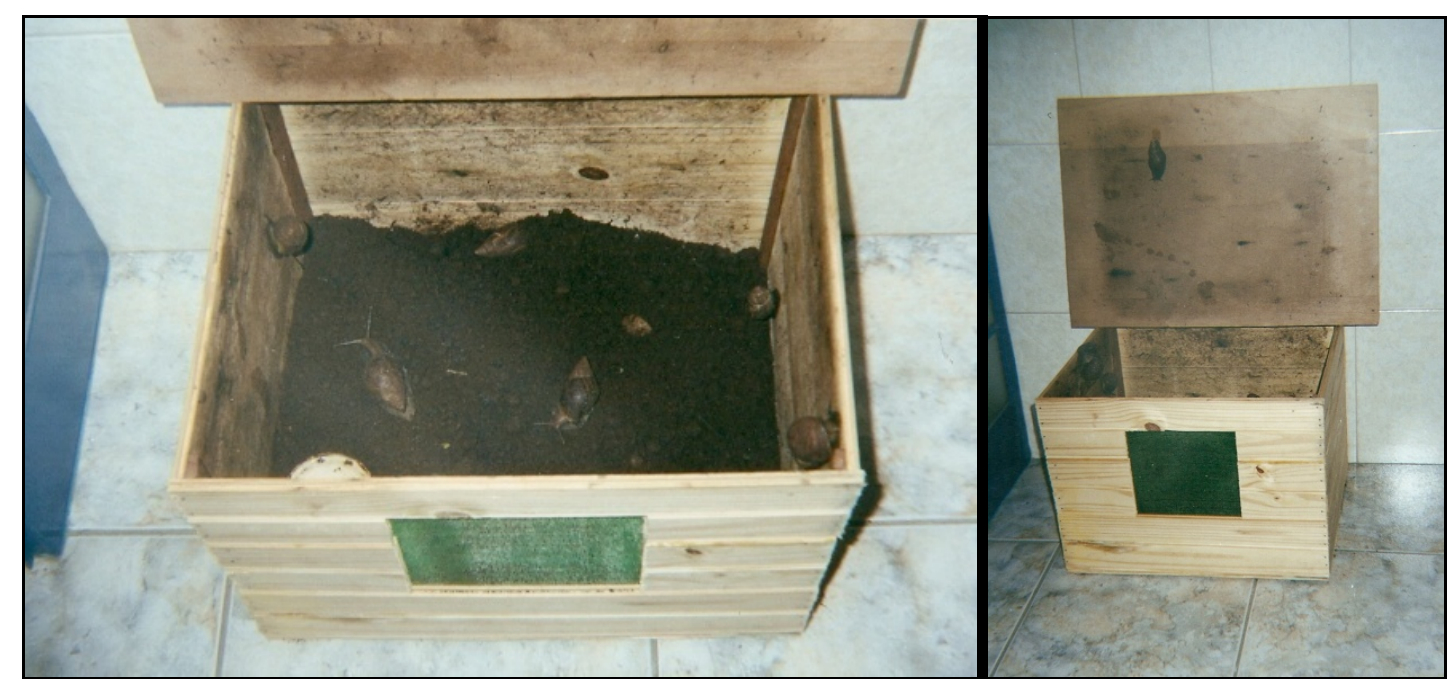

Figura 5: Caixas para criação do escargot Achatina fulica

\subsubsection{Coleta do muco de escargot}

A coleta foi feita através da estimulação manual da superfície corporal, mais especificamente da glândula podal (Figuras 6 e 7), não sendo necessário o sacrifício ou qualquer procedimento que provocasse certa injuria aos animais estudados.

O material foi liofilizado (Figura 8) em liofilizador marca TERRONI® modelo LS 3000 (Figura 9) a fim de manter as características antimicrobianas por um período maior sendo reidratados momentos antes da aplicação no teto dos animais. 


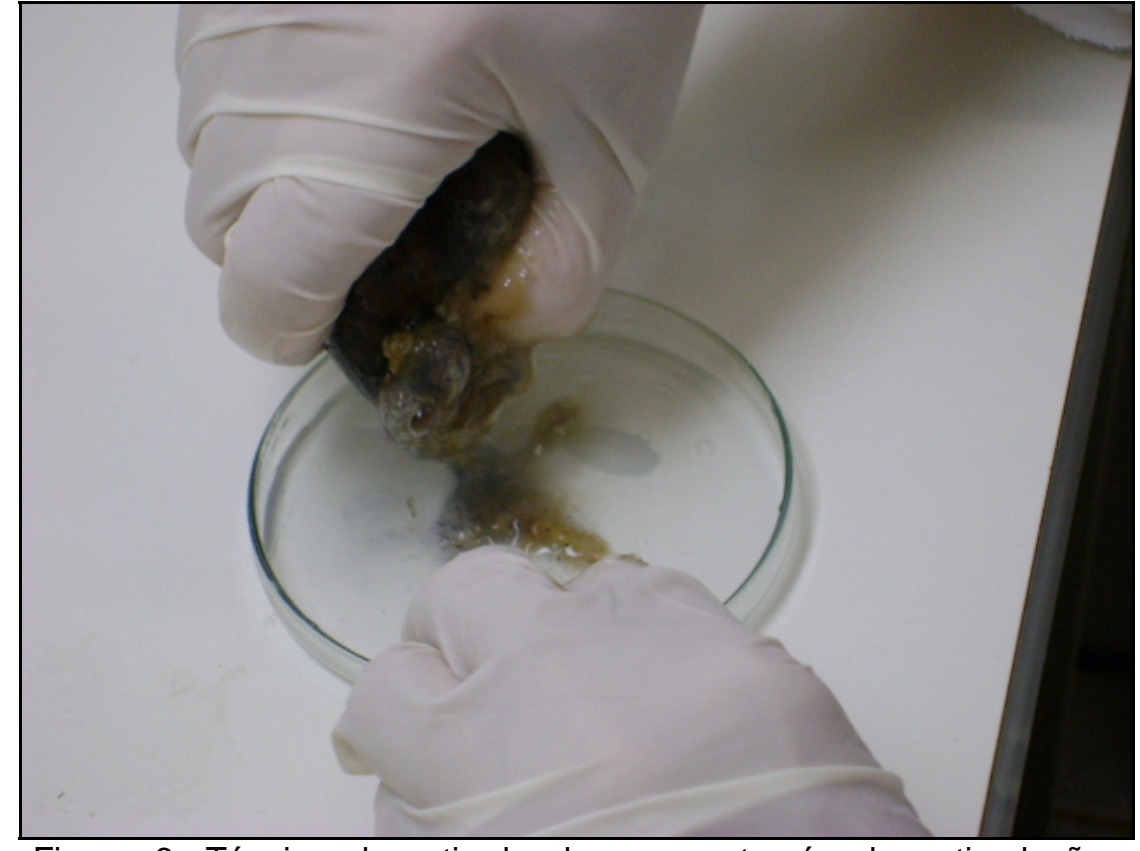

Figura 6: Técnica de retirada do muco através da estimulação da glândula podal

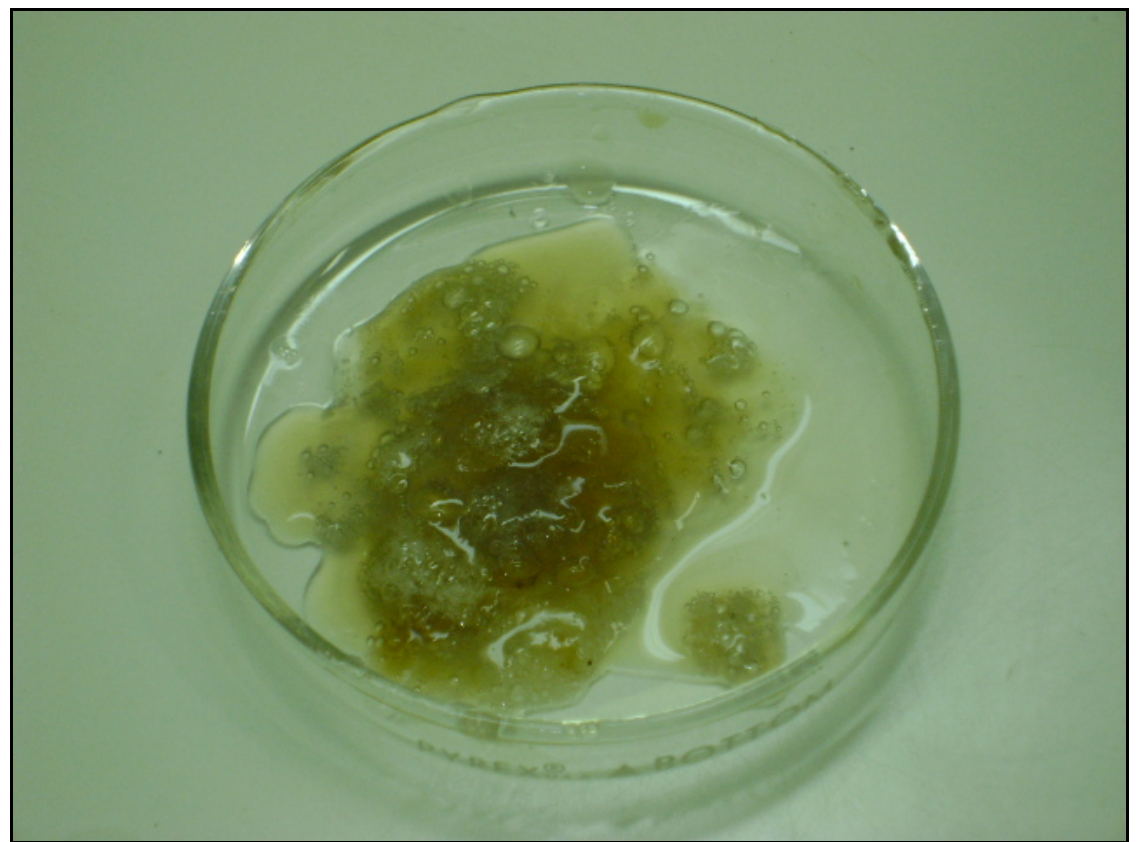

Figura 7: Muco de escargot Achatina fulica, após retirada do animal 


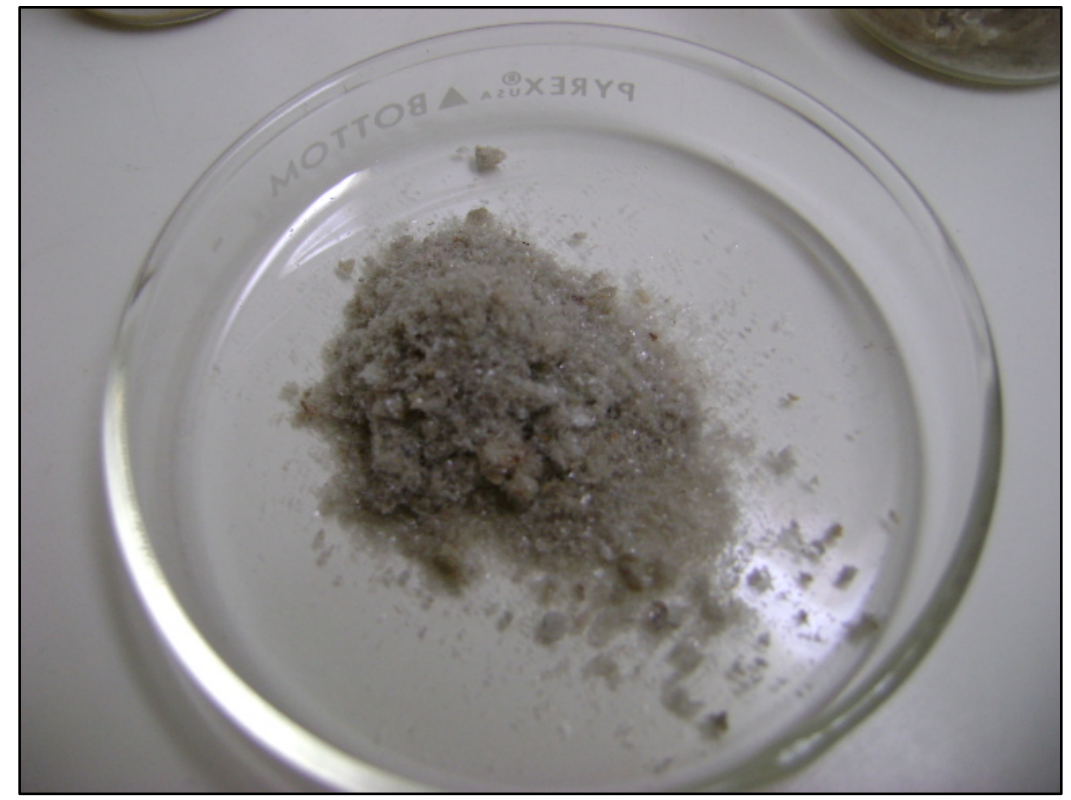

Figura 8: Muco de escargot Achatina fulica, liofilizado

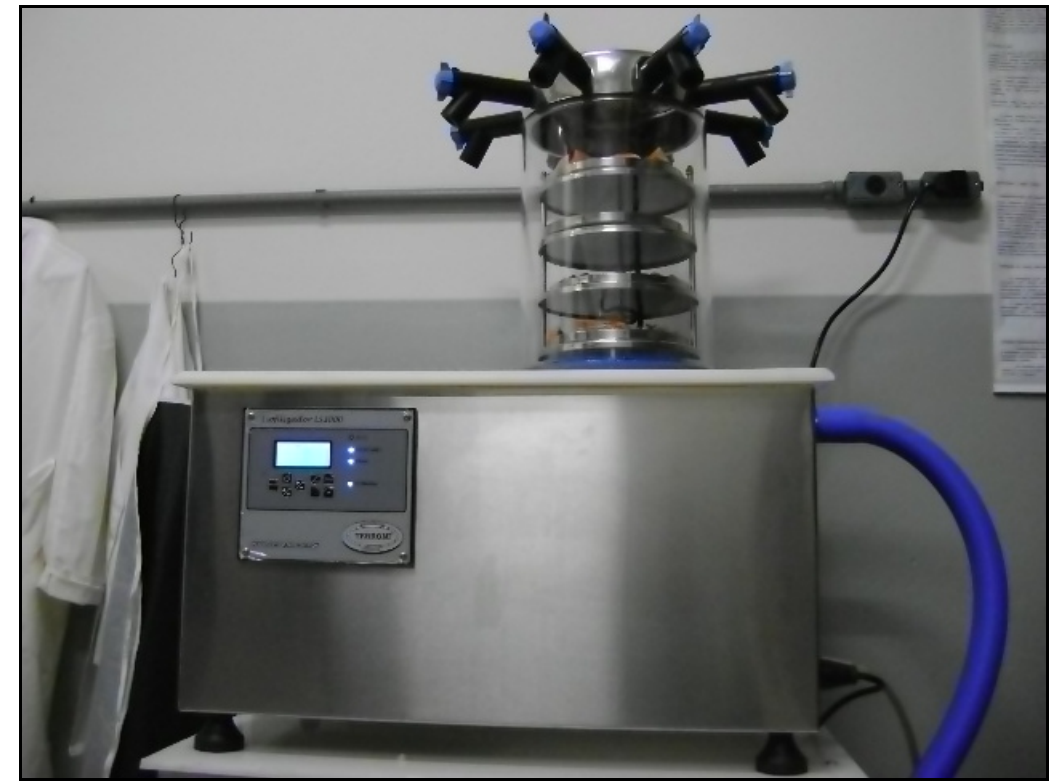

Figura 9: Liofilizador marca TERRONI ${ }^{\circledR}$

Nesta fase ocorreu alta mortalidade dos animais (Figura 10), nos meses de janeiro, fevereiro e março, o que dificultou a extração do muco na quantidade necessária. 


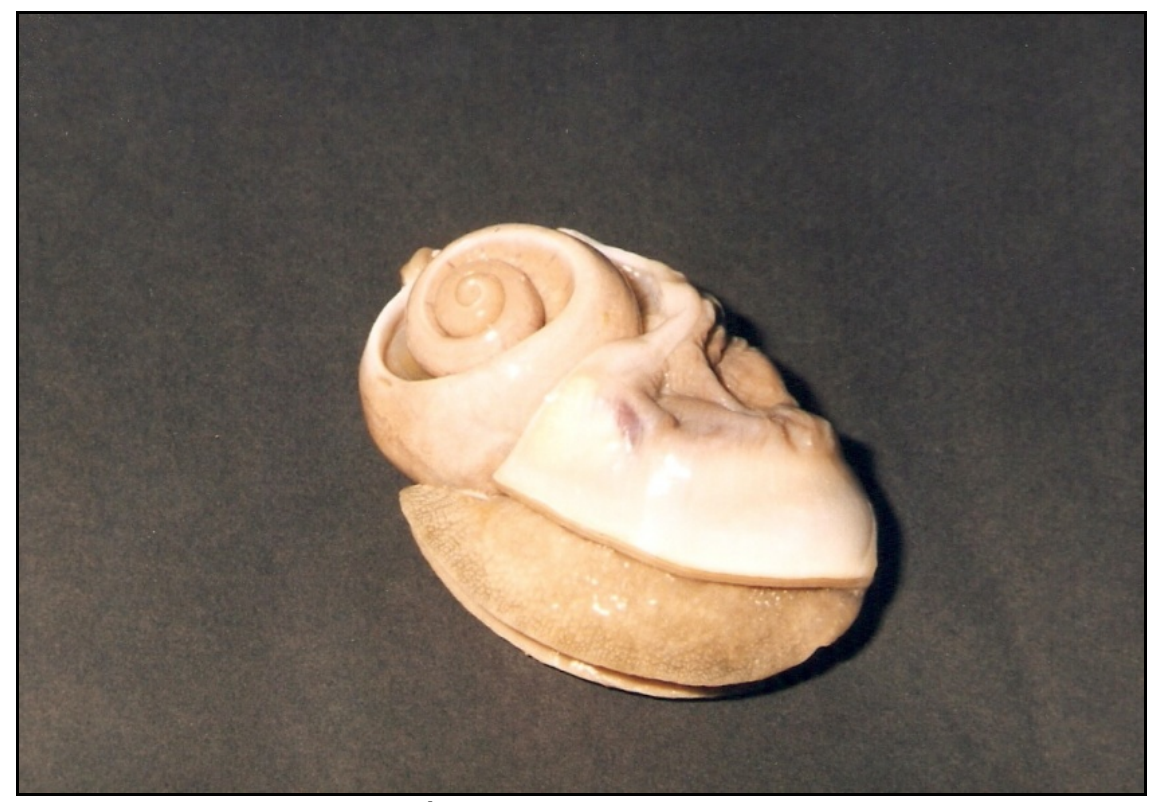

Figura 10: Animal da espécie Achatina monocromatica monocromatica, morto por causa desconhecida

\subsection{SELEÇÃO DAS PROPRIEDADES PARA COLETA DE AMOSTRA}

Foram utilizadas propriedades leiteiras na região de Leme, Pirassununga, Santa Rita do Passa Quatro e Ribeirão Preto, e avaliadas quanto à higiene do local, verificando a ocorrência de mastite e a realização ou não de pré e "pós dipping" durante a ordenha. Três animais de cada propriedade foram utilizados para a realização do estudo, sendo que em cada animal foi feito um tipo de tratamento em cada teto.

\subsubsection{Tratamentos Utilizados}

1) Controle negativo - $\mathrm{O}$ teto somente foi lavado com água antes da ordenha, e não foi imerso em solução desinfetante após a ordenha;

2) Solução com método convencional - O teto foi imerso antes e após a ordenha em uma solução de iodo na forma convencional (200 ppm ).

3) Solução com tecnologia de muco de Achatina $s p$ - O teto foi imerso antes e após a ordenha em uma solução contendo muco de escargot da espécie Achatina fulica. 
4) Solução com tecnologia de muco de Achatina $s p-O$ teto foi imerso antes e após a ordenha em uma solução contendo muco de escargot da espécie Achatina monocromatica monocromatica.

\subsubsection{Preparo do teto da vaca em pré dipping}

A preparação dos tetos controles consistiu em apenas lavagem com água, e secagem com papel toalha, mesma metodologia realizada por Pedrini e Margatho (2003). Para os trabalhos envolvendo o pré dipping foi realizada a imersão do teto em solução comercial a base de iodo (200ppm) onde foi aplicado e permanecendo úmido por quinze segundos e após esse período de aplicação, seco em papel toalha. Os tetos experimentais foram escolhidos ao acaso que foram imersos no muco dos escargot Achatina fulica e Achatina monocromática por 15 segundos em imersão com posterior secagem com papel toalha (Figura 11).

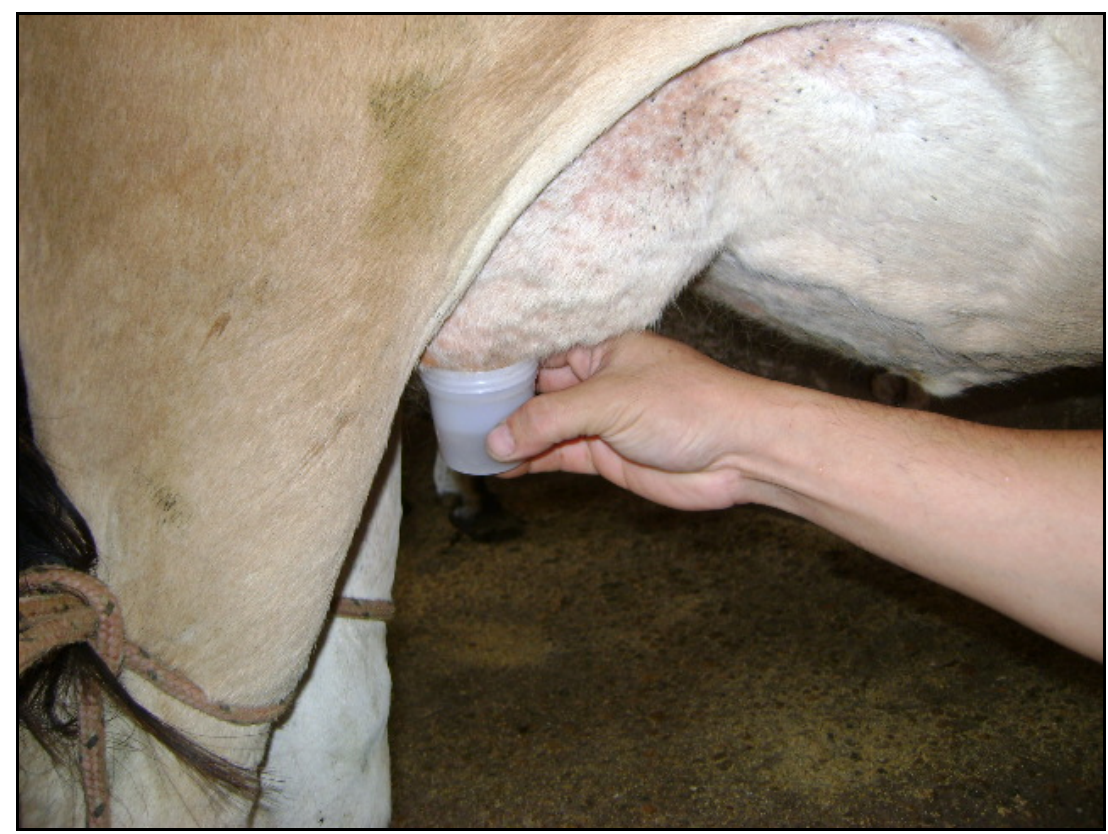

Figura 11: Forma de aplicação dos produtos antisépticos (solução de iodo, muco de escargot Achatina fulica e Achatina monocromatica monocromatica) 


\subsubsection{Total de Tetos Amostrados}

Um total de 12 tetos por propriedade foi examinado antes e após cada procedimento utilizado.

A coleta das amostras foi realizada antes da colocação da teteira da ordenhadeira, com auxilio de "swab" esterilizado (MENDONÇA, 2008). Foram realizados movimentos cruzados sobre uma área de aproximadamente $10 \mathrm{~cm}$ na região mediana do teto (Figura 12).

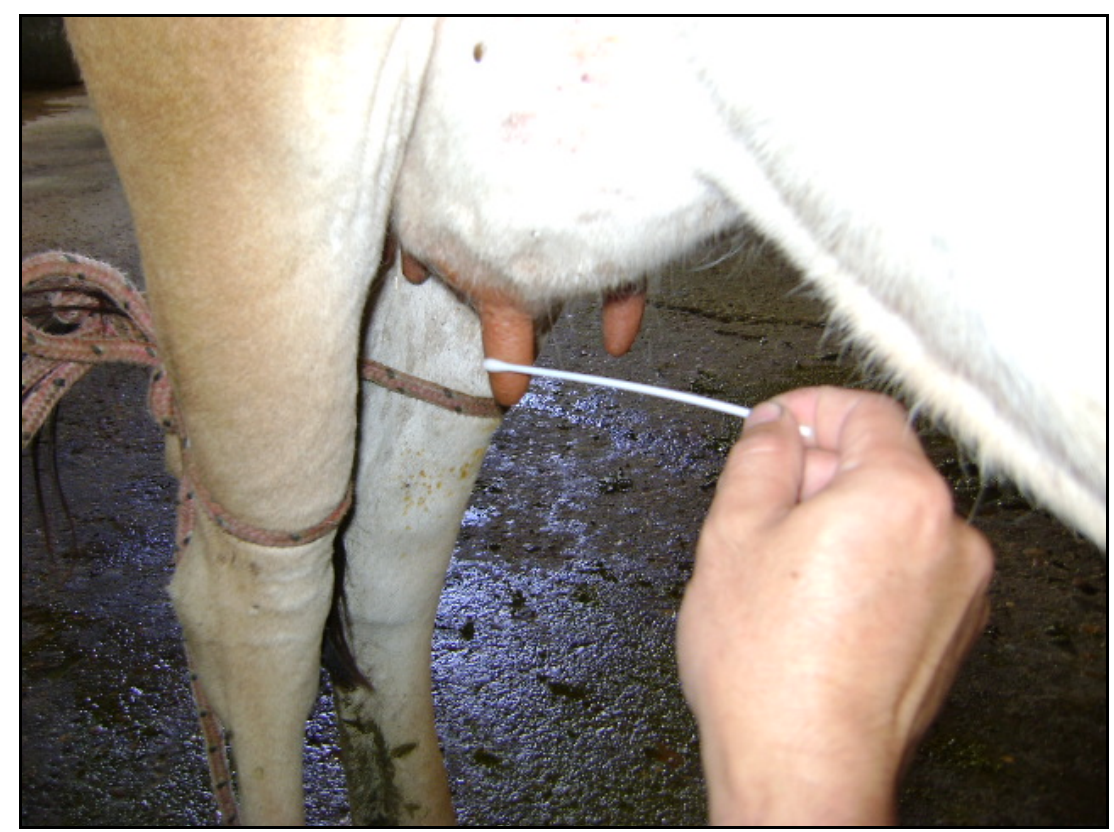

Figura 12: Forma de amostragem com auxilio do "swab"

Após coleta o swab foi colocado imediatamente dentro do tubo de ensaio que continha $10 \mathrm{ml}$ de solução salina $(0,9 \% \mathrm{NaCl})$ e levadas ao laboratório de Genética Molecular e Melhoramento Animal da FMVZ - USP, em Pirassununga em caixas isotérmicas para a realização do isolamento bacteriano (Figura 13). 


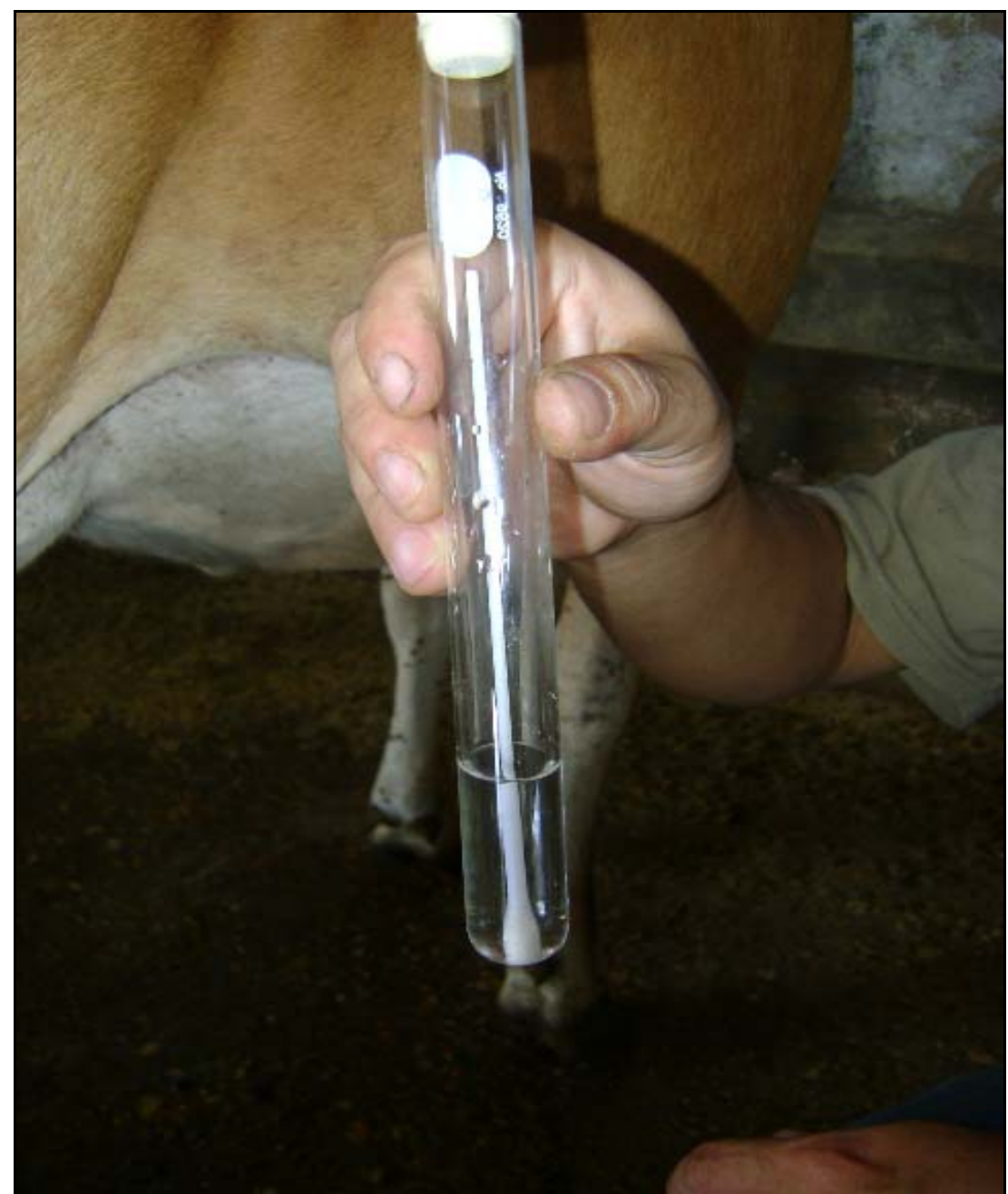

Figura 13: Amostra de "swab" em tubo de ensaio com solução salina $0,9 \%$

\subsubsection{Preparo do teto da vaca em pós dipping}

Logo após a retirada da teteira da ordenhadeira, os tetos foram imersos em solução de iodo ou no muco dos escargots Achatina fulica e Achatina monocromatica monocromatica e a coleta da amostra realizada 20 minutos após a ordenha.

Os animais selecionados para o experimento foram alimentados logo após a ordenha para evitar que eles se deitassem durante o tratamento.

Os mesmos procedimentos foram efetuados quanto à coleta do material a ser analisado, como a utilização do swab no pré dipping. 0 
material foi armazenado em caixas térmicas até o laboratório onde se efetuou a sua analise microbiana.

\subsubsection{Estimativa da densidade de microorganismos}

Foi realizada a verificação semi-quantitativa dos grupos de microorganismos predominantes nas amostras coletadas através do método de esgotamento conforme o esquema mostrado na Figura 14. Neste método temos a predominância da bactéria conforme o local em que ocorra a presença da colônia seja ela na primeira estria foi atribuído o valor de 1+ (uma cruz), caso apareça na primeira e na segunda estria foi atribuído o valor de 2+ (duas cruzes) e caso apareça na primeira, segunda e terceira estria foi atribuída o valor de $3+$ (três cruzes). No caso de ausência de colônias foi considerada negativo 0 (SPENBER, 2001).

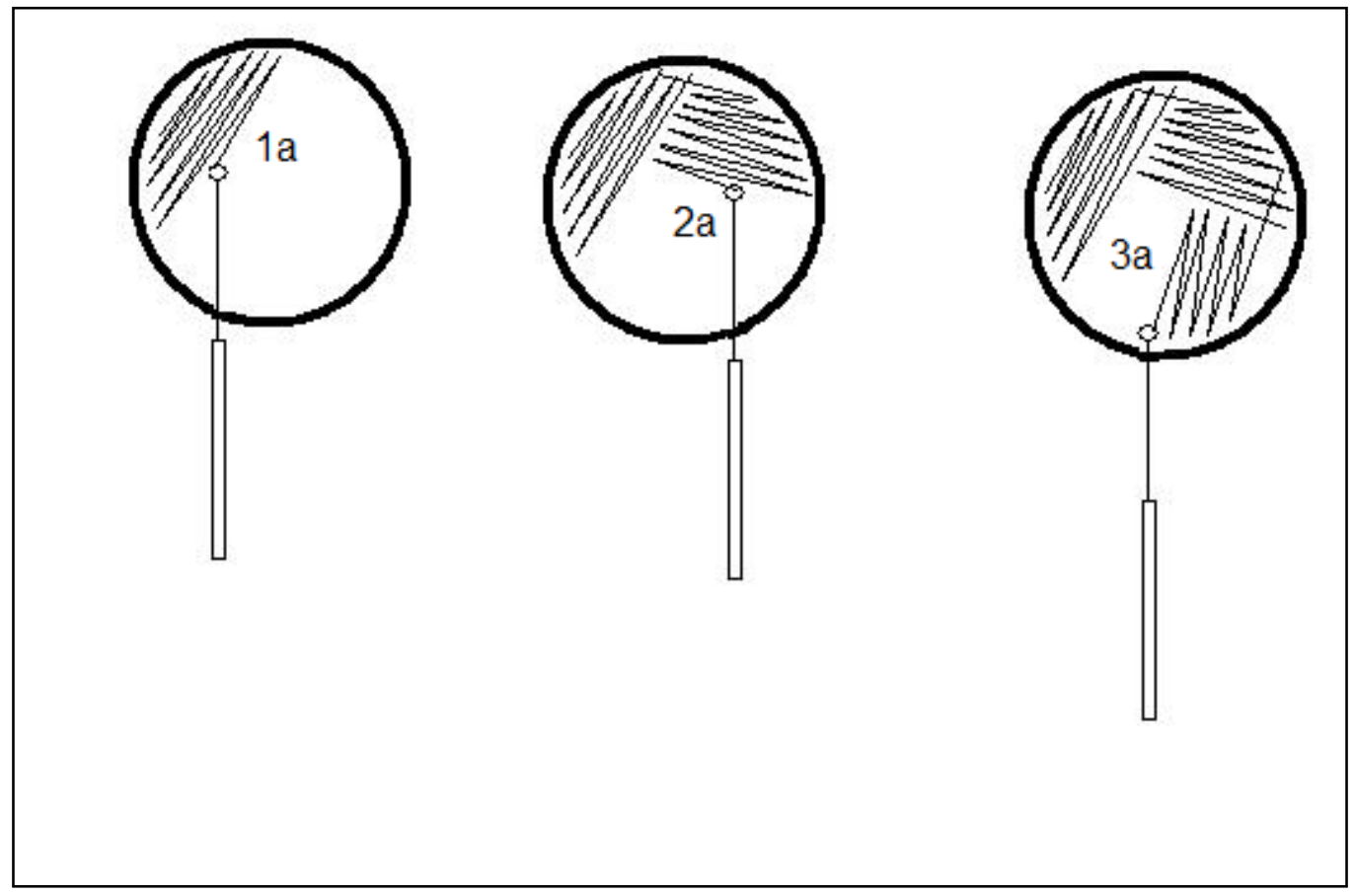

Fonte: Spenber et al., 2001

Figura 14: Método de esgotamento para identificação semi-quatitativa de bactérias. ( $1^{\mathrm{a}}$ aplicação da amostra; $2^{\mathrm{a}}$ espalhamento da $1^{\mathrm{a}}$ estria; $3^{\mathrm{a}}$ espalhamento da $2^{\mathrm{a}}$ estria). 
Os seguintes meios de cultura foram utilizados para os testes:

a. PCA (plate count agar) - para avaliação geral dos microorganismos presentes nos tetos das vacas.

b. Baird-Parker agar - específico para bactérias Gram positivas do grupo Staphylococcos-micrococcus.

c. MacConkey agar - para bactérias Gram negativas do grupo coliformes.

d Sabouraud dextrose agar - específico para bolores e leveduras (incluindo Prototheca).

(Anexo B contém a formulação completa dos meios utilizados)

\subsubsection{Verificação de mastite nos animais}

Para investigação do índice de mastite foram desprezados os dois primeiros jatos de leite efetuando o teste de Tamis (caneca de fundo escuro) conforme metodologia de Blood e Radostitis (1991) e CMT (California Mastits Test), conforme Shalm e Noorlander (1957) de todos os quartos mamários em produção.

Para os quartos que apresentaram resultado positivo duas cruzes (formação de gelatina bastante densa) foram descartados nesta pesquisa, pois o objetivo era de utilizar animais saudáveis, haja vista que a proposta da pesquisa é de caráter profilático e não terapêutico, pois pretendemos diminuir o uso de antibióticos no tratamento devido a resíduos que possam degradar a qualidade do leite e seus derivados. 


\subsubsection{Avaliação dos grupos de microorganismos}

Com o auxilio de uma alça de platina as amostras foram semeadas em estrias (Figura 15) através do método de esgotamento conforme o esquema mostrado na figura 14 , em placas contendo os meios de cultura e incubado a $37^{\circ}$, sendo o crescimento bacteriano avaliado após 48 e 72 horas (Figura 16).

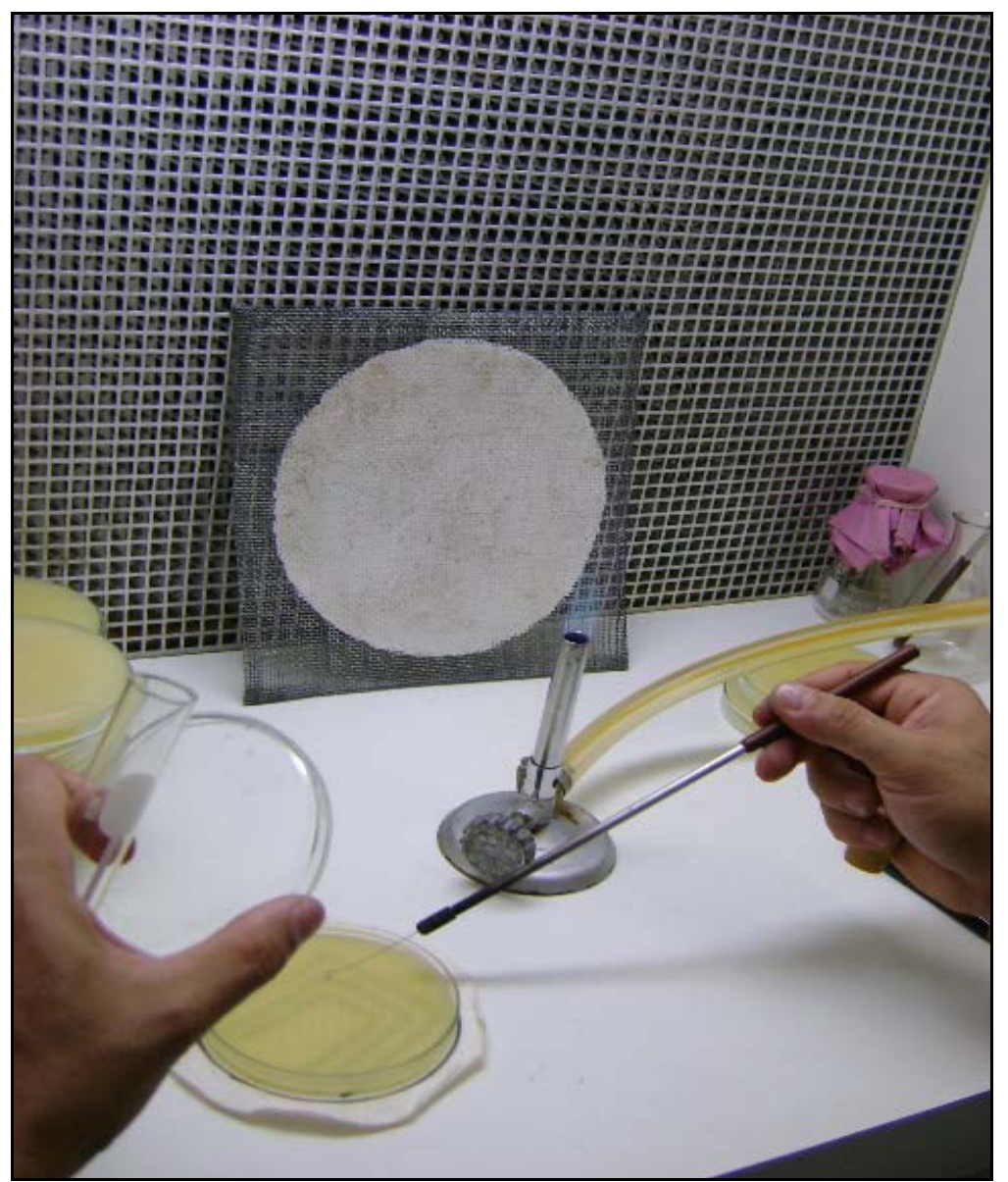

Figura15: Semeadura em placas de Petri contendo meio de cultura. 


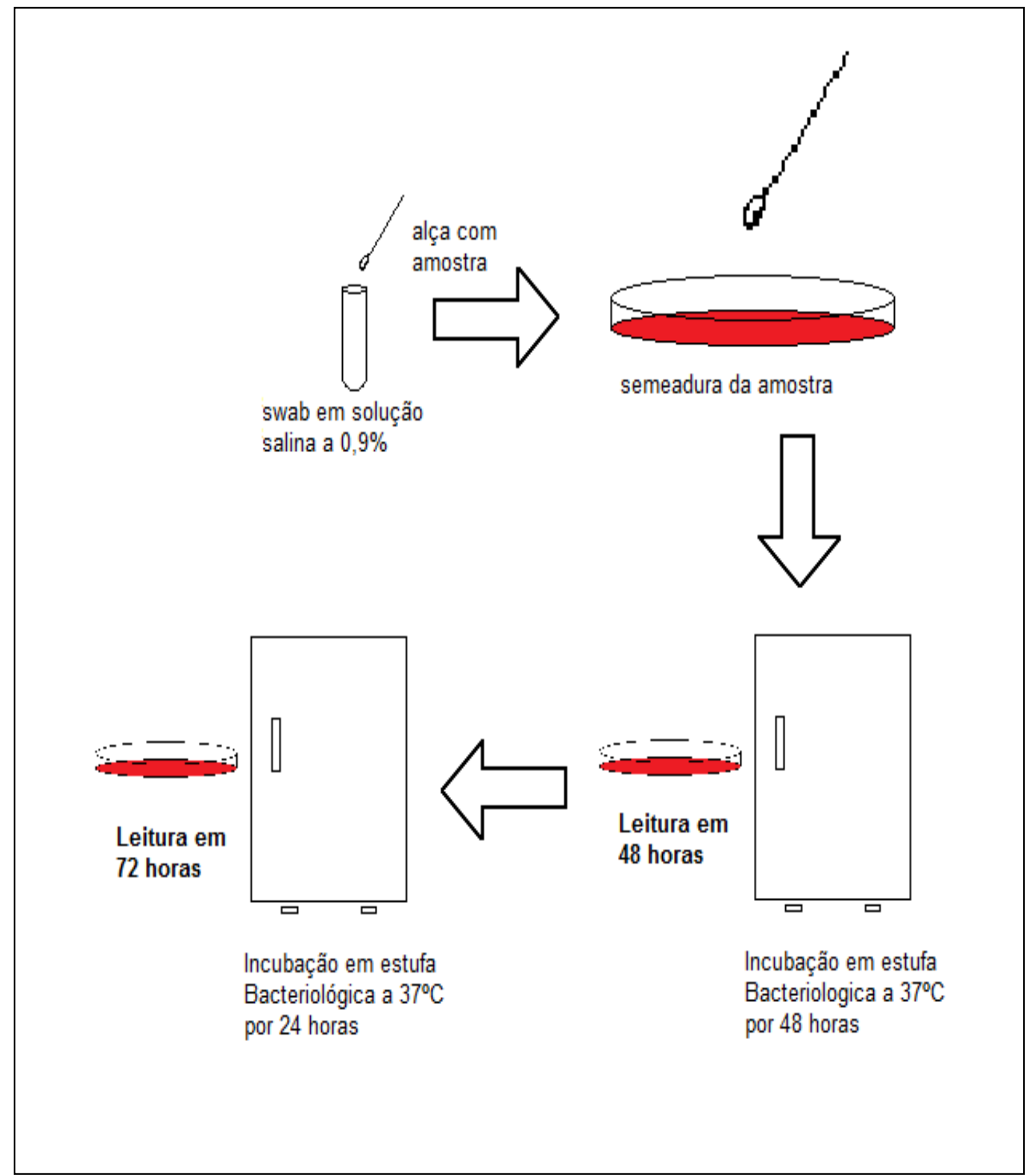

Figura 16: Representação esquemática da metodologia utilizada para o isolamento de microorganismos. 


\subsection{VERIFICAÇÃO DA POSIÇÃO DOS TETOS EM RELAÇÃO À CONTAGEM MICROBIANA}

Foi realizado teste prévio ao trabalho para verificação da posição do teto em relação à quantidade de bactérias encontradas e se isso poderia ou não afetar a distribuição dos tetos em relação aos produtos aplicados.

A coleta de amostras se deu através do esfregaço com "swab" e imersão em tubos de ensaio contendo solução salina a 0,9\%, para manter as amostras viáveis até a semeadura em meios de cultura no laboratório.

Os "Swabs" são utilizados para recolher microorganismos de superfícies que possam estar em contato com alimentos ou não, geralmente empregados devido à facilidade de obter amostras de materiais que se queira analisar. Após a coleta do material este foi acondicionado em recipientes apropriados e levados imediatamente ao laboratório para análise, uma vez que, isto minimiza as possibilidades de crescimento maior de um microorganismo ou a morte de outro (BELL et al.2005).

\subsection{ISOLAMENTO DAS COLÔNIAS DAS PLACAS, MÉTODOS DE COLORAÇÃO DE GRAM , CATALASE E MORFOLOGIA}

O isolamento das colônias dos meios de PCA, Baird-Parker, MacConkey, e Sabouraund, foram realizados a partir da colônia mais isolada (próximas a $3^{\mathrm{a}}$ estria) e predominante na placa. Estas colônias isoladas foram identificadas através do método de coloração de Gram, que consistiu em :

1- Cobrir o esfregaço com violeta de metila e deixar por aproximadamente 60 segundos,

2- Escorrer e sem lavar a lamina cobrir com solução de Lugol e deixar agir por aproximadamente 1 minuto,

3- Escorrer o Lugol e lavar em um filete de água corrente,

4- Adicionar álcool acetonado sobre a lâmina, descorando-a até não desprender mais corante, 
5- Lavar em um filete de água corrente,

6- Cobrir a lamina com fuccina e deixar agir por aproximadamente 30 segundos, lavar em um filete de água corrente,

7- Deixar secar ao ar livre, ou secar suavemente, com o auxilio de papel de filtro limpo,

8- Colocar uma gota de óleo de imersão sobre o esfregaço e ler com objetiva de imersão (100X) em microscópio ótico.

A prova de Catalase foi feita colocando uma gota de solução aquosa de peróxido de hidrogênio (água oxigenada) numa lâmina e, em seguida, com uma alça de platina, colocou uma porção da colônia bacteriana isolada sobre a gota. Esta prova é considerada positiva quando há borbulhamento ou efervescência da gota com a cultura com a liberação do oxigênio.

A prova de morfologia consistiu em observação na microscopia ótica, observando-se a forma de coco ou bastonetes da célula.

\subsection{IDENTIFICAÇÃO BIOQUÍMICA E FISIOLÓGICA DAS CEPAS ISOLADAS.}

Foram utilizados testes preliminares e complementares de identificação bacteriana, testes bioquímicos, sistema de identificação Vitek, sistema de identificação BBL CRYSTAL e comparados com a literatura (ATLAS, 2006; BRENNER et. al., 2005).

Essa etapa foi desenvolvida na Fundação TOSELLO, em Campinas (Anexo C). 


\section{ANÁLISE ESTATÍSTICA}

O principal objetivo deste trabalho consistiu em determinar a eficácia do muco de escargot nos tetos, quando aplicado como pré e "pós-dipping" visando à prevenção ou a redução da incidência de infecções intramamárias. O tratamento proposto nesta pesquisa foi comparar a aplicação de iodo tópico no pré e "pósdipping", que é atualmente o método mais utilizado na pecuária leiteira dos tetos de vacas leiteiras em lactação, com o muco de escargot liofilizado.

Presumiremos então que a eficácia dos dois tratamentos é a mesma, ou seja, que os resultados obtidos com a aplicação de iodo tópico e com muco de escargot liofilizado são, em média, os mesmos e utilizaremos um teste estatístico para definir se essa afirmação é de fato real ou não.

Para isto, utilizaremos um teste chamado Teste t, já que o intuito deste é comparar duas médias. O Teste t é um procedimento estatístico que utiliza amostras para testar uma alegação sobre o valor de um parâmetro populacional. Ele é muito utilizado na área da saúde, para auxiliar na tomada de decisões.

Além disso, nosso conjunto de dados enquadra-se nos pré-requisitos exigidos para a aplicação deste teste, dentre os quais, podemos destacar:

- as amostras serem independentes;

- a população ser normal;

- existir a possibilidade de trabalharmos com números diferentes de observações nas amostras;

Porém, existe o Teste $t$ para observações independentes quando as variâncias são equivalentes, e também quando estas são diferentes. Logo, para definirmos sua utilização, teremos que verificar as variâncias das duas populações. Faremos isso através da aplicação do Teste F.

Após definido o tipo de Teste t que será utilizado, faremos sua aplicação e posterior interpretação dos resultados. 
5.1 Comparativo entre tratamento com solução de iodo, 200ppm (Si) e muco de escargot Achatina fulica (AF),

\section{Cálculo do Teste F}

Nossa hipótese então é: $\mathbf{H}_{0}$ : as variâncias são iguais.

E o nível de significância estabelecido é $\alpha=5 \%$.

Tabela 1 Teste $\mathrm{F}$ duas amostras para variância (solução de iodo, 200pp (Si) e muco de escargot Achatina fulica (AF))

\begin{tabular}{lrr}
\hline & \multicolumn{1}{c}{$\mathrm{Si}$} & \multicolumn{1}{c}{$\mathrm{AF}$} \\
\hline Média & 2,375 & 1,375 \\
Variância & 3,395833333 & 0,729166667 \\
Observaçốes & 4 & 4 \\
gl & 3 & 3 \\
$F$ & 4,657142857 & \\
P(F $<=f)$ uni-caudal & 0,119251165 & \\
F crítico uni-caudal & 9276628154 & \\
\hline
\end{tabular}

Após a realização dos cálculos via Excel, é preciso comparar o valor de $\mathrm{F}$ na tabela. Toda vez que o valor calculado for maior ou igual ao da tabela, rejeita-se a hipótese de que as variâncias são iguais ao nível de significância de 5\%.

Como em nosso caso o valor calculado $(4,65)$ é menor que o valor encontrado na tabela $(9,27)$, aceita-se a hipótese e, com isso, decidimos pela utilização do Teste t para variâncias equivalentes.

\section{Cálculo do Teste t para variâncias equivalentes}

Nossa hipótese então é: $\mathbf{H}_{0}$ : as médias são iguais.

E o nível de significância estabelecido é $\alpha=5 \%$. 
Tabela 2 Teste T: duas amostras presumindo variâncias equivalentes (solução de iodo, 200ppm (Si) e muco de escargot Achatina fulica (AF))

\begin{tabular}{lrr}
\hline & \multicolumn{1}{c}{ Si } & \multicolumn{1}{c}{ AF } \\
\hline Média & 2,375 & 1,375 \\
Variância & 3,395833333 & 0,729166667 \\
Observaçóes & 4 & 4 \\
Variância agrupada & 2,0625 & \\
Hipótese da diferença de média & 0 & \\
gl & 6 & \\
Stat $t$ & 0,984731928 & \\
P(T<t) uni-caudal & 0,18139184 & \\
t critico uni-caudal & 1,943180274 & \\
$P(T<t)$ bi-caudal & 0,36278368 & \\
t critico bi-caudal & 2,446911846 & \\
\hline
\end{tabular}

Como em nosso caso o valor calculado para t $(0,98)$ é menor que o da tabela $(2,44)$, concluímos que as médias são iguais, ao nível de significância de $5 \%$ e com 6 graus de liberdade. Em termos práticos, podemos afirmar que a variação da população de microorganismos foi, em média, igual para as duas classes. Ou seja, não houve variação significativa na diferença entre a população de microorganismos presentes no tratamento com solução de iodo, 200ppm (Si) e no tratamento com muco de escargot Achatina fulica (AF), o que indica que ambos apresentam mesmo grau de eficácia.

5.2 Comparativo entre tratamento com solução de iodo, 200ppm (Si) e muco de escargot Achatina monocromatica. monocromatica (AM)

Realizaremos o mesmo procedimento anterior, porém num comparativo entre solução e solução de iodo, 200ppm (Si) e muco de escargot Achatina monocromatica. monocromatica (AM)

\section{Cálculo do Teste $\mathrm{F}$}

Nossa hipótese então é: $\mathrm{H}_{0}$ : as variâncias são iguais.

E o nível de significância estabelecido é $\alpha=5 \%$. 
Tabela 3 Teste $\mathrm{F}$ duas amostras para variância (solução de iodo, 200pp (Si) e muco de escargot Achatina monocromatica. monocromatica (AM)

\begin{tabular}{lrr}
\hline & Si & AM \\
\hline Média & 2,375 & 1,5 \\
Variância & 3,395833333 & 2 \\
Obseruaçốes & 4 & 4 \\
gl & 3 & 3 \\
F & 1,697916667 & \\
F critico uni-caudal & 0,337170236 & \\
\hline
\end{tabular}

Como em nosso caso o valor calculado $(1,69)$ foi menor que o valor encontrado na tabela $(9,27)$, aceitou-se a hipótese e, com isso, decidimos pela utilização do Teste t para variâncias equivalentes.

\section{Cálculo do Teste t para variâncias equivalentes}

Nossa hipótese então é: $\mathbf{H}_{0}$ : as médias são iguais.

E o nível de significância estabelecido é $\alpha=5 \%$.

Tabela 4 Teste T duas amostras para variância (solução de iodo, 200pp (Si) e muco de escargot Achatina monocromatica. monocromatica (AM)

\begin{tabular}{lrr}
\hline & \multicolumn{1}{c}{ Si } & AM \\
\hline Média & 2,375 & 1,5 \\
Variância & 3,395833333 & 2 \\
Observaçöes & 4 & 4 \\
Variância agrupada & 2,697916667 & \\
Hipótese da diferença de mé dia & 0 & \\
gl & 6 & \\
Stat t & 0,753370804 & \\
P(T<=t) uni-caudal & 0239867387 & \\
t crítico uni-caudal & 1,943180274 & \\
P(T<=t) bi-caudal & 0,479734774 & \\
t critico bi-caudal & 2,446911846 & \\
\hline
\end{tabular}

Como em nosso caso o valor calculado para t $(0,75)$ é menor que o da tabela $(2,44)$, concluímos que as médias são iguais, ao nível de significância de 5\% e com 6 graus de liberdade. Em termos práticos, podemos afirmar que a variação da população de microorganismos foi, em média, igual para as duas classes. Ou seja, não houve variação significativa na diferença entre a população de microorganismos presentes no tratamento e solução de iodo, 200ppm (Si) e muco de escargot 
Achatina monocromatica. monocromatica (AM). Para as análises mostradas acima foi utilizado o programa computacional Microsoft Office exel 2007 para Windows XP.(2007). 


\section{RESULTADO E DISCUSSÃO}

A coleta do muco de escargot Achatina fulica e Achatina monocromatica monocromatica, feita por estimulação podal atendeu as expectativas, fornecendo material adequado para todos os procedimentos realizados em nossos estudos. Segundo Caetano (1998) ao estudar a utilização da secreção do muco de escargot em processos de cicatrização tecidual de ratos hairless adotou o mesmo procedimento. Desta forma essa metodologia empregada, foi padronizada no Heliciário experimental Profa . $\mathrm{Dr}^{\mathrm{a}}$. Lor Cury e em função também do bem estar animal, haja vista que inúmeros trabalhos, principalmente os desenvolvidos no Japão (KIM et. al, 2007; KOBOTA et. al, 1985 e IGUCHI et. al, 1985) fazem uso de choque elétrico no pé do animal para a retirada do muco, o que produz mais muco, porém, nossas pesquisas, bem como a nossa filosofia de trabalho, não nos permite adotar tal procedimento, pois se prioriza o não sofrimento e o respeito a todas as formas de vida.

\subsection{Efeito da posição dos tetos na contagem microbiana}

O exame microbiológico de amostras coletadas da região anterior e posterior dos tetos foi analisado nesse estudo, pois, um dos questionamentos que hipotetizamos era de que a região posterior dos tetos apresentaria uma maior contaminação quando comparada à região anterior, de modo que as medidas de controle e tratamento pudessem ser adotadas com maior eficiência, porem os resultados foram diferentes dos hipotetizados (Tabelas 1 e 2) ou seja, foi verificado que não há diferença na população de microorganismos contaminantes entre os diferentes tetos: anterior direito $(A D)$, anterior esquerdo $(A E)$, posterior direito $(P D)$, posterior esquerdo $(P E)$. As pequenas diferenças nas médias de quatro animais (duas de propriedade A e duas de propriedade B) devem ser atribuídas á variação ao acaso, pois o desvio padrão de $\pm 0,403$ da contagem do grupo Staphylococcusmicrococcus e de $\pm 0,512$, da contagem total de microorganismos são comparáveis à diferença entre os tetos de diferentes animais. Essas 
estimativas foram feitas sem a aplicação dos agentes de desinfecção (iodo ou muco de escargot) uma vez que a finalidade era a verificação da posição dos tetos com relação á população de microorganismos presentes.

Além disso, a média geral das estimativas para a contagem de Staphylococcus-micrococcus e de contagem total foi de 2,19 e 2,56, respectivamente. $\mathrm{O}$ valor obtido da contagem total apresentou-se ligeiramente superior quando comparado ao valor do Staphilococcus micrococcus atendendo nossas expectativas, pois, o meio Baird-Parker usado neste procedimento é seletivo para este microorganismo e portanto, pode-se esperar inibição de outras bactérias.

Um resultado importante obtido nesse ensaio foi que é possível distribuir os diferentes tratamentos nos animais selecionados de forma randomizada entre os quatro tetos, sem se preocupar com o efeito da posição dos mesmos nos resultados a serem obtidos. 
Tabela 1 Avaliação das posições dos tetos; Anterior Direito (AD); Anterior Esquerda (AE); Anterior Esquerdo ( $\mathrm{AE}$ ) e Posterior Esquerdo (PE), na contagem de microorganismos do grupo Staphylococcus-micrococcus (Baird Parker). São apresentadas as médias e os respectivos desvios padrões

\begin{tabular}{l|c|c|c|c|c}
\hline Propriedade A & AD & AE & PD & PE & Media \\
\hline Animal 1 & $2+$ & $2+$ & $2+$ & $3+$ & $2,25 \pm 0,5$ \\
Animal 2 & $3+$ & $2+$ & $2+$ & $2+$ & $2,25 \pm 0,5$ \\
\hline Propriedade B & AD & AE & PD & PE & Media \\
\hline Animal 1 & $2+$ & $2+$ & $2+$ & $2+$ & $2,00 \pm 0,0$ \\
Animal 2 & $2+$ & $3+$ & $2+$ & $2+$ & $2,25 \pm 0,5$ \\
Média \pm DV & $2,25 \pm 0,5$ & $2,25 \pm 0,5$ & $2,00 \pm 0,0$ & $2,25 \pm 0,5$ & $2,19^{\star} \pm 0,403$ \\
\hline
\end{tabular}

* média seguida de desvio padrão dos valores obtidos dos 16 tetos analisados

Nota: $3+$ : crescimento nas três faixas; $2+$ : crescimento nas duas faixas; $1+$ : crescimento na primeira faixa; 0 : sem crescimento.

Tabela 2 Avaliação das posições dos tetos; Anterior Direito (AD); Anterior Esquerda (AE); Anterior Esquerdo (AE) e Posterior Esquerdo (PE), na contagem na contagem de microorganismos total (Plate Count Agar). São apresentadas as médias e os respectivos desvios padrões

\begin{tabular}{l|c|c|c|c|c}
\hline Propriedade A & AD & AE & PD & PE & Media \pm DV \\
\hline Animal 1 & $3+$ & $3+$ & $3+$ & $2+$ & $2,75 \pm 0,5$ \\
Animal 2 & $2+$ & $3+$ & $2+$ & $2+$ & $2,25 \pm 0,5$ \\
\hline Propriedade B & AD & AE & PD & PE & \\
\hline Animal 1 & $3+$ & $2+$ & $3+$ & $2+$ & 2,5 \\
Animal 2 & $2+$ & $3+$ & $3+$ & $3+$ & 2,75 \\
Média DV & $2,5 \pm 0,5$ & $2,75 \pm 0,5$ & $2,75 \pm 0,5$ & $2,25 \pm 0,5$ & $2,56 \pm 0,512$ \\
\hline
\end{tabular}

* média seguida de desvio padrão dos valores obtidos dos 16 tetos analisados Nota: $3+$ : crescimento nas três faixas; $2+$ : crescimento nas duas faixas; $1+$ : crescimento na primeira faixa; 0 : sem crescimento. 


\subsection{EFEITOS DOS DIFERENTES TRATAMENTOS DOS TETOS}

Sabe-se que a higienização dos tetos é uma das etapas mais importantes para a obtenção de leite com boa qualidade e prevenção de mastites e, portanto, imprescindível para manutenção da própria sanidade do animal (PANKEY e MARGHATO, 2003). Desta forma, o presente estudo visou comparar a aplicação de várias substâncias sépticas no pré e pós dipping e compará-las ao uso do muco de escargot, já que este possui uma substância antibacteriana e cicatrizante (KIM et. al, 1996), desta forma, os efeitos dos diferentes tratamentos para desinfecção dos tetos na ordenha estão apresentados nas tabelas 3, 4 e 5 .

Tabela 7 Estimativa dos diferentes grupos de microorganismos presentes nos tetos de vacas não tratadas (Co) e tratadas com solução de iodo, 200ppm (Si); muco de escargot Achatina fulica (AF), muco de escargot Achatina monocromatica. monocromatica (AM) da propriedade $\mathrm{A}$

\begin{tabular}{|c|c|c|c|c|c|c|c|c|c|c|c|c|}
\hline & \multicolumn{4}{|c|}{ Animal 1} & \multicolumn{4}{|c|}{ Animal 2} & \multicolumn{4}{|c|}{ Animal 3} \\
\hline & Co & Si & $\mathrm{AF}$ & AM & Co & Si & AF & AM & Co & Si & AF & AM \\
\hline & \multicolumn{12}{|c|}{ Crescimento em PCA } \\
\hline Pré dipping & $1+$ & 0 & 0 & 0 & $1+$ & $1+$ & 0 & 0 & $2+$ & 0 & $1+$ & $1+$ \\
\hline \multirow[t]{2}{*}{ Pós dipping } & $2+$ & 0 & $1+$ & 0 & $2+$ & 0 & $1+$ & $1+$ & $2+$ & $1+$ & $1+$ & $1+$ \\
\hline & \multicolumn{12}{|c|}{ Crescimento em MacConkey } \\
\hline Pré dipping & $1+$ & 0 & $1+$ & 0 & 0 & 0 & 0 & 0 & 0 & 0 & 0 & 0 \\
\hline \multirow[t]{2}{*}{ Pós dipping } & $1+$ & 0 & 0 & 0 & 0 & 0 & 0 & 0 & $1+$ & 0 & $1+$ & $1+$ \\
\hline & \multicolumn{12}{|c|}{ Crescimento em Baird Parker } \\
\hline Pré dipping & $1+$ & 0 & 0 & 0 & $1+$ & 0 & 0 & 0 & $2+$ & 0 & 0 & 0 \\
\hline \multirow[t]{2}{*}{ Pós dipping } & $1+$ & 0 & $1+$ & 0 & $1+$ & 0 & 0 & 0 & $2+$ & 0 & 0 & 0 \\
\hline & \multicolumn{12}{|c|}{ Crescimento em Sabouroud* } \\
\hline Pré dipping & $1+$ & 0 & 0 & 0 & $1+$ & 0 & 0 & $1+$ & $2+$ & 0 & 0 & 0 \\
\hline Pós dipping & $2+$ & 0 & 0 & 0 & $1+$ & 0 & 0 & 0 & $2+$ & 0 & 0 & $1+$ \\
\hline
\end{tabular}

Legenda:

Nota: $3+$ : crescimento nas três faixas; $2+$ : crescimento nas duas faixas; $1+$ : crescimento na primeira faixa; 0 : sem crescimento

* dados de crescimento bacteriano 
Tabela $8 \quad$ Estimativa dos diferentes grupos de microorganismos presentes nos tetos de vacas não tratadas (Co) e tratadas com solução de iodo, 200ppm (Si); muco de escargot Achatina fulica (AF), muco de escargot Achatina monocromatica. monocromatica (AM) da propriedade $B$

\begin{tabular}{|c|c|c|c|c|c|c|c|c|c|c|c|c|}
\hline & \multicolumn{4}{|c|}{ Animal 1} & \multicolumn{4}{|c|}{ Animal 2} & \multicolumn{4}{|c|}{ Animal 3} \\
\hline & Co & Si & AF & AM & Co & Si & AF & AM & Co & Si & AF & AM \\
\hline & \multicolumn{12}{|c|}{ Crescimento em PCA } \\
\hline Pré dipping & $2+$ & $1+$ & 0 & 0 & $1+$ & $1+$ & 0 & $1+$ & $2+$ & 0 & $1+$ & 0 \\
\hline \multirow[t]{2}{*}{ Pós dipping } & $2+$ & $1+$ & 0 & $1+$ & $2+$ & 0 & 0 & 0 & $1+$ & 0 & $1+$ & 0 \\
\hline & \multicolumn{12}{|c|}{ Crescimento em MacConkey } \\
\hline Pré dipping & $1+$ & $1+$ & 0 & 0 & 0 & 0 & 0 & 0 & 0 & 0 & 0 & 0 \\
\hline \multirow[t]{2}{*}{ Pós dipping } & 0 & 0 & 0 & 0 & 0 & 0 & 0 & 0 & 0 & 0 & 0 & 0 \\
\hline & \multicolumn{12}{|c|}{ Crescimento em Baird Parker } \\
\hline Pré dipping & $2+$ & $1+$ & 0 & 0 & $2+$ & $1+$ & $1+$ & $1+$ & $3+$ & 0 & 0 & 0 \\
\hline \multirow[t]{2}{*}{ Pós dipping } & $1+$ & $1+$ & 0 & 0 & $1+$ & 0 & $1+$ & $1+$ & $1+$ & $1+$ & 0 & 0 \\
\hline & \multicolumn{12}{|c|}{ Crescimento em Sabouroud* } \\
\hline Pré dipping & $3+$ & $1+$ & 0 & 0 & $2+$ & $1+$ & 0 & $1+$ & $2+$ & 0 & 0 & 0 \\
\hline Pós dipping & $1+$ & $1+$ & 0 & 0 & $1+$ & 0 & 0 & 0 & $2+$ & $1+$ & 0 & 0 \\
\hline
\end{tabular}

Legenda:

Nota: $3+$ : crescimento nas três faixas; $2+$ : crescimento nas duas faixas; $1+$ : crescimento na primeira faixa; 0: sem crescimento.

* dados de crescimento bacteriano 
Tabela 9 Estimativa dos diferentes grupos de microorganismos presentes nos tetos de vacas não tratadas (Co) e tratadas com solução de iodo, 200ppm (Si); muco de escargot Achatina fulica (AF), muco de escargot Achatina monocromatica. monocromatica (AM) da propriedade $\mathrm{C}$

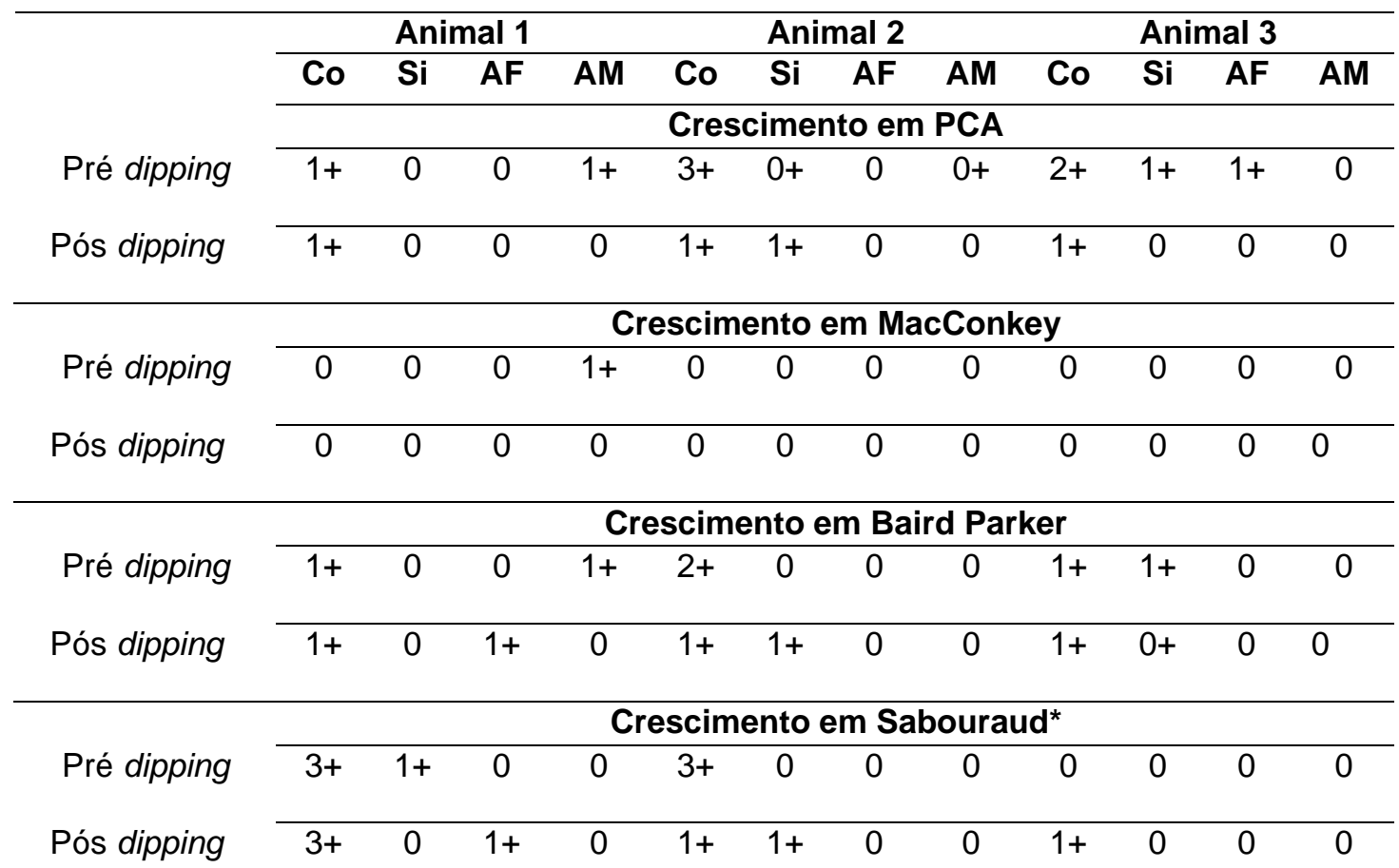

Legenda:

Nota: $3+$ : crescimento nas três faixas; $2+$ : crescimento nas duas faixas; $1+$ : crescimento na primeira faixa; 0: sem crescimento

* dados de crescimento bacteriano

Como foi visto nos resultados referentes ao efeito da posição dos tetos na contagem microbiana (Tabelas 1 e 2), as contagens totais de microorganismos em meio de cultura PCA obtido dos tetos de animais não tratados (controle), apresentaram crescimentos de 1 (na primeira faixa) e 3 (nas três faixas), nas três propriedades analisadas. Já as contagens de Staphylococcus, feitas com o uso do meio Baird-Parker, mostraram ser ligeiramente inferior ao crescimento do meio PCA; o que confirma os resultados preliminares apresentados nas tabelas 1 e 2 . Ainda, as contagens de coliformes feitas usando o meio MacConkey foram bem baixas, apresentando valores entre 0 (sem crescimento) e 1 (crescimento na primeira faixa); resultado este em acordo com o meio utilizado, ou seja, extremamente seletivo para enterobactérias (SANTOS e FONSECA, 2007). 
Os resultados obtidos no meio Agar Sabouraud (Tabelas 3, 4 e 5) que é altamente específico para fungos e bolores foram discrepantes devido ao crescimento de bactérias. Este dado obtido pode ter ocorrido por duas (2) hipóteses, dentre elas, podemos colocar a influencia do $\mathrm{pH}$ correspondente à água destilada presente no Laboratório de Genética Molecular da FMVZ USP, Pirassununga, pois esta é de teor alcalino, o que por premissa esta relacionado a um pH elevado. No entanto, apesar de não termos aferido este parâmetro, Ruiz (1992) comenta que para este tipo de meio o pH final deve permanecer em 5,8, ou seja característico de meio levemente ácido; além deste fato, uma outra possível hipótese seria de que o meio utilizado por nós não foi acrescido de Cloranfenicol, antibiótico de largo espectro recomendado para amostras com grande quantidades de bactérias (RUIZ, 1992).

O tratamento com solução de iodo a 200ppm, muco de escargot Achatina fulica (AF), e muco de escargot Achatina monocromatica monocromatica (AM), mostrou ser eficaz na redução da população microbiana dos tetos.

O tratamento com desinfetantes à base de iodo, clorexidina e cloro (hipoclorito de sódio), são comumentes utilizados nas propriedades rurais para o controle de população de microorganismos dos tetos nas ordenhas, diminuindo no pré dipping a contaminação, reduzindo em até $50 \%$ a taxa de novas infecções causadas por patógenos (SANTOS e FONSECA., 2007).

A tabela 6 mostra a somatória de valores obtidos na estimativa da população microbiana de tetos das vacas examinadas das três propriedades. 
Tabela 10 Somatória dos valores atribuídos às contagens de todos os microorganismos presentes nos tetos de vacas não tratadas (Co) e tratadas com solução de iodo, 200ppm (Si); muco de escargot Achatina fulica (AF), muco de escargot Achatina monocromatica. monocromatica (AM) das propriedadedas A, B e C São apresentadas as médias

\begin{tabular}{|c|c|c|c|c|}
\hline \multicolumn{5}{|c|}{ Tetos Totais $(\mathrm{n}=36)$} \\
\hline & Co & Si & $\mathrm{AF}$ & $\overline{A M}$ \\
\hline & \multicolumn{4}{|c|}{ Crescimento em PCA } \\
\hline Pré dipping & 15 & 5 & 2 & 3 \\
\hline Pós dipping & 14 & 4 & 3 & 4 \\
\hline \multirow[t]{2}{*}{ Média } & 14,5 & 4,5 & 2,5 & 3,5 \\
\hline & \multicolumn{4}{|c|}{ Crescimento em MacConkey } \\
\hline Pré dipping & 3 & 0 & 1 & 0 \\
\hline Pós dipping & 2 & 0 & 1 & 1 \\
\hline \multirow[t]{2}{*}{ Média } & 2,5 & 0,0 & 1,0 & 0,5 \\
\hline & \multicolumn{4}{|c|}{ Crescimento em Baird Parker } \\
\hline Pré dipping & 15 & 3 & 1 & 2 \\
\hline Pós- dipping & 10 & 2 & 2 & 1 \\
\hline \multirow[t]{2}{*}{ Média } & 12,5 & 2,5 & 1,5 & 1,5 \\
\hline & \multicolumn{4}{|c|}{ Crescimento em Sabouraud } \\
\hline Pré dipping & 17 & 3 & 0 & 1 \\
\hline Pós dipping & 14 & 2 & 1 & 0 \\
\hline Média & 15,5 & 2,5 & 0,5 & 0,5 \\
\hline
\end{tabular}

Essa tabela mostra claramente que a população de microorganismos totais (meio PCA) é ligeiramente superior a de Staphylococcus - micrococcus e a população de coliforme é bem inferior. A contagem de bolores e leveduras foi prejudicada pela ineficiência da seletividade do meio utilizado.

Os tratamentos para o muco extraído de Achatina fulica (AF) e Achatina monocromatica monocromatica (AM) foram igualmente eficientes quando comparadas com o iodo, evidenciando desta forma, a ação antibacteriana do muco descrita por Iguchi et. al. (1982).

Um aspecto observado foi que o método semi-quantitativo, utilizado a partir da técnica de esgotamento, descrita por Brenner et. al. (2005) adaptada por nós, mostrou-se ser bastante prática, rápida e simples para estimar a população microbiana dos tetos das vacas a campo. Nossa técnica é simples, porque a 
transferência é feita de suspensão de microorganismos obtida diretamente dos tetos na superfície da placa, não havendo, portanto, a necessidade de diluições em série e plaqueamentos múltiplos que exigem uma série de tubos, pipetas e placas estéreis, além de condições especiais e instalações adequadas, como por exemplo, as exigidas em laboratórios específicos. Assim, após a coleta, o plaqueamento pode ser conduzido no local improvisando na própria fazenda, coletando-se amostras diretamente do animal, necessitando apenas levar os materiais de coleta e meios em placas apropriados já estéreis. Dessa forma, acreditamos, que essa técnica, possa em muito auxiliar novas pesquisas otimizando o tempo para contagem de bactérias, no entanto, alguns cuidados na transferência da suspensão bacteriana às placas devem continuar sendo obedecidas, como por exemplo a utilização da alça de platina. Acreditamos que, através da utilização do meio adequado e seletivo nessa etapa, podemos identificar preliminarmente o microorganismo presente, ou seja, se é uma enterobactéria ou um estafilococos, se é fungo, bolor ou bactéria, somado a isso, essa adaptação da técnica pode ser aplicada para outras situações similares, como por exemplo, determinação de microorganismos, como por exemplo aos patogênicos responsáveis por infecções cutâneas dos animais, essa é apenas um exemplo das muitas possibilidades de utilização.

\subsection{IDENTIFICAÇÃO PRELIMINAR DOS MICROORGANISMOS PRESENTES}

As tabelas 7, 8, 9 e 10 mostram as características das colônias, das células, reação de Catalase e Coloração de Gram das diversas cepas isoladas das placas dos meios PCA, Baird-Parker, Mac Conkey, e Sabouraund. 
Tabela 11- Características Morfológicas das amostras de bactérias, Catalase e de Coloração de Gram das colônias isoladas do meio de cultura PCA.

\begin{tabular}{|c|c|c|c|c|c|}
\hline $\mathrm{N}^{*}$ & Pré-dipping & Característica & Catalase & Morfologia & Gram \\
\hline 1 & $\begin{array}{l}\text { Achatina } \\
\text { monocromatica } \\
\text { monocromatica }\end{array}$ & $\begin{array}{l}\text { Colônia transparente, } \\
\text { branca, brilhante, } \\
\text { redonda }\end{array}$ & Positiva & Bastonete & Negativo \\
\hline 2 & Controle & $\begin{array}{l}\text { Colônia branca, } \\
\text { redonda, brilhante }\end{array}$ & Positiva & Bastonete & Negativo \\
\hline 3 & Achatina fulica & $\begin{array}{l}\text { Colônia branca, } \\
\text { redonda, brilhante }\end{array}$ & Positiva & Bastonete & Negativo \\
\hline 4 & Controle & $\begin{array}{l}\text { Colônia amarela, lisa, } \\
\text { opaca }\end{array}$ & Positiva & Cocos & Positivo \\
\hline 5 & Controle & $\begin{array}{l}\text { Colônia amarela, lisa, } \\
\text { opaca }\end{array}$ & Positiva & Cocos & Positivo \\
\hline 6 & Iodo & $\begin{array}{l}\text { Colônia amarela, } \\
\text { redonda, opaco }\end{array}$ & Positiva & Cocos & Positivo \\
\hline 7 & $\begin{array}{l}\text { Achatina } \\
\text { monocromatica } \\
\text { monocromatica }\end{array}$ & $\begin{array}{l}\text { Colônia amarela, } \\
\text { redonda irregular }\end{array}$ & Positiva & Cocos & Positivo \\
\hline 8 & Controle & $\begin{array}{l}\text { Colônia amarela, } \\
\text { redonda, opaco }\end{array}$ & Positiva & Cocos & Positivo \\
\hline 9 & Achatina fulica & $\begin{array}{l}\text { Colônia transparente, } \\
\text { brilhante, redonda }\end{array}$ & Positiva & Bastonete & Negativo \\
\hline 10 & $\begin{array}{l}\text { Achatina } \\
\text { monocromatica } \\
\text { monocromatica }\end{array}$ & $\begin{array}{l}\text { Colônia creme, } \\
\text { redonda, opaco }\end{array}$ & Positiva & Cocos & Positivo \\
\hline 11 & Controle & $\begin{array}{l}\text { Colônia amarela, lisa, } \\
\text { opaca, regular }\end{array}$ & Positiva & Cocos & Positivo \\
\hline 12 & Achatina fulica & $\begin{array}{l}\text { Colônia branca, } \\
\text { brilhante, redonda }\end{array}$ & Positiva & Bastonete & Negativo \\
\hline $\mathbf{N}^{0}$ & Pós-dipping & Característica & Catalase & Morfologia & Gram \\
\hline 13 & Achatina fulica & $\begin{array}{l}\text { Colônia amarela, lisa, } \\
\text { redonda regular }\end{array}$ & Positiva & Cocos & Positivo \\
\hline 14 & Controle & $\begin{array}{l}\text { Colônia amarela, } \\
\text { redonda irregular, opaca }\end{array}$ & Positiva & Cocos & Positivo \\
\hline 15 & Controle & $\begin{array}{l}\text { Colônia creme, lisa, } \\
\text { redonda }\end{array}$ & Positiva & Cocos & Positivo \\
\hline 16 & Iodo & $\begin{array}{l}\text { Colônia creme, regular, } \\
\text { redonda }\end{array}$ & Positiva & Cocos & Positivo \\
\hline
\end{tabular}

Legenda:

* $\mathrm{N}=$ número da amostra 
Tabela 12 Características Morfológicas das amostras de bactérias; Catalase e Coloração de Gram, de colônias isoladas do meio de cultura para Staphylococus-micrococcus - Baird Parker

\begin{tabular}{|c|c|c|c|c|c|}
\hline$\overline{N^{\circ}}$ & Pré-dipping & Característica & Catalase & Morfologia & Gram \\
\hline$\overline{17}$ & Controle & $\begin{array}{l}\text { Colônia amarela, } \\
\text { redonda, opaco }\end{array}$ & Positiva & Cocos & Positivo \\
\hline $\mathbf{N}^{0}$ & Pós-dipping & Característica & Catalase & Morfologia & Gram \\
\hline 18 & Controle & $\begin{array}{l}\text { Colônia amarela, } \\
\text { redonda, opaco }\end{array}$ & Positiva & Cocos & Positivo \\
\hline 19 & Achatina fulica & $\begin{array}{l}\text { Colônia amarela, } \\
\text { redonda, regular }\end{array}$ & Positiva & Cocos & Positivo \\
\hline 20 & $\begin{array}{l}\text { Achatina } \\
\text { monocromatica } \\
\text { monocromatica }\end{array}$ & $\begin{array}{l}\text { Colônia amarela, } \\
\text { opaco, irregular }\end{array}$ & Positiva & Cocos & Positivo \\
\hline 21 & Iodo & $\begin{array}{l}\text { Colônia amarela, } \\
\text { redonda, opaco }\end{array}$ & Positiva & Cocos & Positivo \\
\hline 22 & $\begin{array}{l}\text { Achatina } \\
\text { monocromatica } \\
\text { monocromatica }\end{array}$ & $\begin{array}{l}\text { Colônia amarela, } \\
\text { redonda, opaco }\end{array}$ & Positiva & Cocos & Positivo \\
\hline
\end{tabular}

Tabela 13 Características Morfológicas das amostras de bactérias; Catalase e Coloração de Gram, de colônias isoladas do meio de cultura para coliformes - MacConkey

\begin{tabular}{|c|c|c|c|c|c|}
\hline $\mathrm{N}^{\circ}$ & Pré-dipping & Característica & Catalase & Morfologia & Gram \\
\hline 23 & Controle & $\begin{array}{l}\text { Colônia branca, } \\
\text { redonda, brilhante }\end{array}$ & Positiva & Bastonete & Negativo \\
\hline 24 & Controle & $\begin{array}{l}\text { Colônia branca, lisa, } \\
\text { brilhante }\end{array}$ & Positiva & Bastonete & Negativo \\
\hline 25 & Controle & $\begin{array}{l}\text { Colônia branca, } \\
\text { redonda, brilhante }\end{array}$ & Positiva & Bastonete & Negativo \\
\hline $\mathbf{N}^{\circ}$ & Pós-dipping & Característica & Catalase & Morfologia & Gram \\
\hline 26 & Controle & $\begin{array}{l}\text { Colônia branca, } \\
\text { redonda, brilhante }\end{array}$ & Positivo & Bastonete & Negativo \\
\hline 27 & $\begin{array}{l}\text { Achatina } \\
\text { monocromatica } \\
\text { monocromatica }\end{array}$ & $\begin{array}{l}\text { Colônia branca, } \\
\text { redonda, brilhante }\end{array}$ & Positivo & Bastonete & Negativo \\
\hline
\end{tabular}

${ }^{*} \mathrm{~N}=$ número da amostra 
Tabela 14 Características Morfológicas das amostras de bactérias; Catalase e Coloração de Gram, de colônias isoladas do meio de cultura para fungos, bolores e algas - Saboraund

\begin{tabular}{|c|c|c|c|c|c|}
\hline $\mathbf{N}^{\circ}$ & Pré-dipping & Característica & Catalase & Morfologia & Gram \\
\hline 28 & Achatina fulica & $\begin{array}{l}\text { Colônia pequena, } \\
\text { redonda, opaca, } \\
\text { transparente }\end{array}$ & Positiva & Cocos & Positivo \\
\hline 29 & Controle & $\begin{array}{l}\text { Colônia branca, } \\
\text { redonda, brilhante }\end{array}$ & Positiva & Bastonete & Negativo \\
\hline 30 & Controle & $\begin{array}{l}\text { Colônia amarela, } \\
\text { redonda, opaca, } \\
\text { cremosa }\end{array}$ & Positiva & Cocos & Positivo \\
\hline $\mathbf{N}^{\circ}$ & Pós-dipping & Característica & Catalase & Morfologia & Gram \\
\hline 31 & Controle & $\begin{array}{l}\text { Colônia amarela, } \\
\text { redonda, lisa }\end{array}$ & Positiva & Cocos & Positivo \\
\hline 32 & Iodo & $\begin{array}{l}\text { Colônia branca, } \\
\text { redonda, brilhante }\end{array}$ & Positiva & Bastonete & Negativo \\
\hline 33 & Iodo & $\begin{array}{l}\text { Colônia amarela, } \\
\text { redonda, opaca }\end{array}$ & Positiva & Cocos & Positivo \\
\hline
\end{tabular}

De acordo com a tabela 7, das dezesseis (16) cepas analisadas, onze (11) cepas isoladas do meio de contagem total (PCA) foram de cocos Gram positiva e cinco de bastonetes de Gram negativo. As cepas isoladas do meio de Baird-Parker (Tabela 8), que é seletivo para bactérias do grupo Staphylococus- micrococcus foram todas (seis cepas) de cocos Gram positiva. Já as cepas isoladas em meio MacConkey, (Tabela 9) para coliformes, foram todas de bastonete Gram negativo. As colônias isoladas no meio Sabouraud (Tabela 10) que deveriam ser de fungos e/ou bolores tiveram seus crescimentos comprometidos devido ao crescimento de bactérias (conforme descrito no item, 5.2), no entanto procurou-se saber quais bactérias seriam estas e assim foram identificadas seis (6) cepas, sendo duas (2) bastonetes Gram negativa e quatro (4) cocos Gram positiva.

Para o isolamento das cepas das placas dos diferentes meios de cultura, foram utilizadas as colônias que apresentaram melhor crescimento entre as três faixas, o que nos possibilita sugerir, que as colônias selecionadas são 
predominantes da amostra original. Assim, as bactérias predominantes em todas as amostras ou eram Cocos Gram positiva ou Bastonetes Gram negativa, sendo, posteriormente confirmadas como sendo Staphylococus aureus e Micrococcus luteus; e Klebsiella pneomoniae e Acinetobacter junni respectivamente.

\subsection{IDENTIFICAÇÃO DAS CEPAS ISOLADAS}

A tabela 11 mostra o resultado da identificação, fisiologia, e bioquímica das oito cepas selecionadas de diferentes meios usadas no isolamento feito em nosso laboratório. Esta análise foi feita no departamento de Coleção de Culturas Tropical da Fundação André Tosello Campinas/SP e foi acompanhada por nós. Observamos que testes preliminares e complementares foram realizados para determinar-se qual o melhor teste seria empregado para a confirmação e identificação dos microorganismos, assim, dentre os testes realizados por este laboratóro, destacaram-se dois, o VITEK e o BBL, que foram utilizados para as nossas amostragens de cepas. Os mesmos procedimentos em termos de cultura e crescimento utilizados por nós foram realizados neste laboratório, o que nos deixou bastante otimistas quanto aos futuros resultados (resultado completo dos testes realizados está apresentado no Anexo C).

Os resultados preliminares obtidos das análises feitas por este Laboratório estão em concordância com os nossos, o que nos permite assegurar que as identificações das cepas isoladas dos tetos das vacas submetidas aos diferentes tratamentos correspondem aos achados de literatura (PEDRINI, 2003; MARTH e STEELE, 2001), e correspondem a bactérias cocos Gram positiva; Staphylococcus aureus e Micrococcus luteus, e as bactérias bastonetes Gram negativas; Klebsiella pneumoniae e a Acinetobacter junii. 
Tabela 15 Resultado da identificação, fisiologia, e bioquímica das oito cepas isoladas de diferentes meios usadas no isolamento.

\begin{tabular}{lll}
\hline $\begin{array}{l}\mathbf{N}^{\circ} \text { da } \\
\text { amostra }\end{array}$ & \multicolumn{1}{c}{ Característica } & Resultado \\
\hline $\mathbf{2}$ & $\begin{array}{l}\text { Colônia transparente branca, elevada, circular, } \\
\text { regular, brilhante, forma de bastonete, Gram } \\
\text { negativo, catalase positiva }\end{array}$ & Klebsiella pneumoniae \\
& $\begin{array}{l}\text { Colônia transparente branca, elevada, circular, } \\
\text { regular, brilhante, forma de bastonete, Gram } \\
\text { negativo, catalase positiva }\end{array}$ & Acinetobacter junii \\
& &
\end{tabular}

\begin{tabular}{|c|c|c|}
\hline 4 & $\begin{array}{l}\text { Colônia amarela, borda irregular, opaco, } \\
\text { cremosa, forma de cocos, Gram positivo, } \\
\text { catalase positiva }\end{array}$ & Micrococcus luteus \\
\hline 6 & $\begin{array}{l}\text { Colônia amarela, redonda, opaco, cremosa, } \\
\text { forma de cocos, Gram positivo, catalase positiva }\end{array}$ & Staphylococcus aureus \\
\hline
\end{tabular}

$\begin{array}{lll}10 & \begin{array}{l}\text { Colônia amarela, redonda, opaco, cremosa, } \\ \text { forma de cocos, Gram positivo, catalase positiva }\end{array} & \text { Staphylococcus aureus } \\ 13 & \begin{array}{l}\text { Colônia amarela, redonda, opaco, cremosa, } \\ \text { forma de cocos, Gram positivo, catalase positiva }\end{array} & \text { Staphylococcus aureus } \\ & \end{array}$

32 Colônia transparente branca, elevada, circular,
regular, brilhante, forma de bastonete, Gram
negativo, catalase positiva


É importante lembrar que essas espécies são habitantes normais na pele de animais e, portanto, podem causar mastite se houver condições favoráveis ao seu desenvolvimento como algum tipo de trauma no animal ou aparecimento de linhagens mais agressivas de bactérias (MARTH e STEELE, 2001). Sabe-se que a mastite é um dos principais fatores que pode comprometer a qualidade do leite e acarretar prejuízos para pecuária leiteira, além de comprometer o tecido glandular (LANGONI, 2007) e dentre os microorganismos encontrados neste processo, estão os Staphylococcus aureus, determinados sorotipos de Escherichia coli e outros, com potencialidade zoótica, que podem ser passivelmente encontrados tanto no leite como em seus derivados (LANGONI, 2007). Assim, a tabela 12 lista os principais agentes causadores da mastite e dentre esses, são encontrados aqueles identificados por nós, Staphylococcus aureus (cocos Gram positivo) e Klebsiella pneumoniae (bastonete Gram negativo) considerados os mais comuns presentes em infecções da glândula mamária (MARTH e STEELE 2001). Por outro lado em nossos estudos não foram identificadas bactérias do solo (Bacillus cereus, Brevibacterium, Corynebacterium, Arthrobacter, Nocardia e Mychobacterium - bastonetes Gram positiva e Catalase positiva), bactérias lácticas (Streptococcus spp, Crinebacterium $s p$ - Gram positiva, catalase negativa, em bastonetes ou cocos) que normalmente habitam plantas e vegetais em decomposição e mucosa gástricas e genito-urinária dos animais (HOLT et al, 2000; MARTH e STEELE 2001). Em adição, também não foram detectados coliformes habitates naturais do trato intestinal dos animais (Escherichia coli, e Enterobacter aerogenes) (WEINNER et al, 2001).

É possível que essas bactérias estejam presentes nas amostras coletada, mas o seu número deve ser bem reduzido, pois não foi possível ser detectado pela técnica empregada. Para estes ensaios foram selecionados animais saudáveis e em propriedades de padrão higiênico razoável. Talvez por esta razão não foi detectada nenhuma bactéria que possa causar enfermidade nos tetos. Possivelmente se a vaca estiver com algum tipo de infecção no úbere ou nos tetos, o método poderá detectar o grupo responsável por essa enfermidade.

A função principal da desinfecção dos tetos durante e após a ordenha é reduzir a população de microorganismos aí presentes. Isso é conseguido pelo uso de agentes desinfetantes, como solução de iodo, cloro e amônia quaternária (GALTOM et. al, 1986). O efeito danoso da mastite é bastante conhecido sendo os mais importantes a redução na produção de leite, leite descartado em função do 
tratamento, custos com medicamentos e serviços veterinários ou até mesmo a perda da vaca (descarte e morte prematura) em casos mais graves, comprometendo a qualidade do leite produzido (SANTOS e FONSECA, 2007).

O tratamento e a prevenção da mastite estão associadas as boas práticas de higiene, que envolvem o homem, o animal e o ambiente que são considerados os principais fatores responsáveis pela qualidade do leite produzido (AMARAL et. al, 2004).

O muco de escargot das espécies testadas Achatina fulica (AF) e Achatina monocromatica monocromatica (AM), mostrou ser igualmente eficiente no controle da população de microorganismos presente na superfície dos tetos. Cabe ressaltar a aqui que lyomasa e colaboradores (2002) ao utilizarem esse muco, em injúrias teciduais observaram a presença de uma substancia, glicoprotéica, no qual parece estar relacionada com os efeitos de cicatrização, melhorando o aspecto da pele. Da mesma forma, podemos inferir que o aspecto dos tetos após a utilização do muco, apresentaram-se mais hidratados, e isto pode estar correlacionado a esta glicoproteina, também denominada de Achacin (JEONG et. al, 2001) que além de proporcionar tal efeito contribuiu para a minimização da microbiota patogênica comumente encontrada no processo de mastite. Desta forma enumeramos aqui algumas peculiaridades que foram observadas e merecem ser destacadas:

1. O muco é uma solução orgânica e, portanto, a forma de atuação deve ser diferente das soluções de iodo ou outro antiséptico químico.

2. Por esse motivo o efeito sobre a pele e mucosa do teto deve ser diferente podendo ser usado em vacas que por algum motivo seja sensível ao agente mineral.

3. O efeito residual do muco pode ser diferente do iodo sendo interessante o seu uso quando se deseja uma pratica mais prolongada dos tetos (esse fato deve ser testado por uma pesquisa futura). 
Tabela 16 Principais agentes causadores de mastite em vacas leiteiras

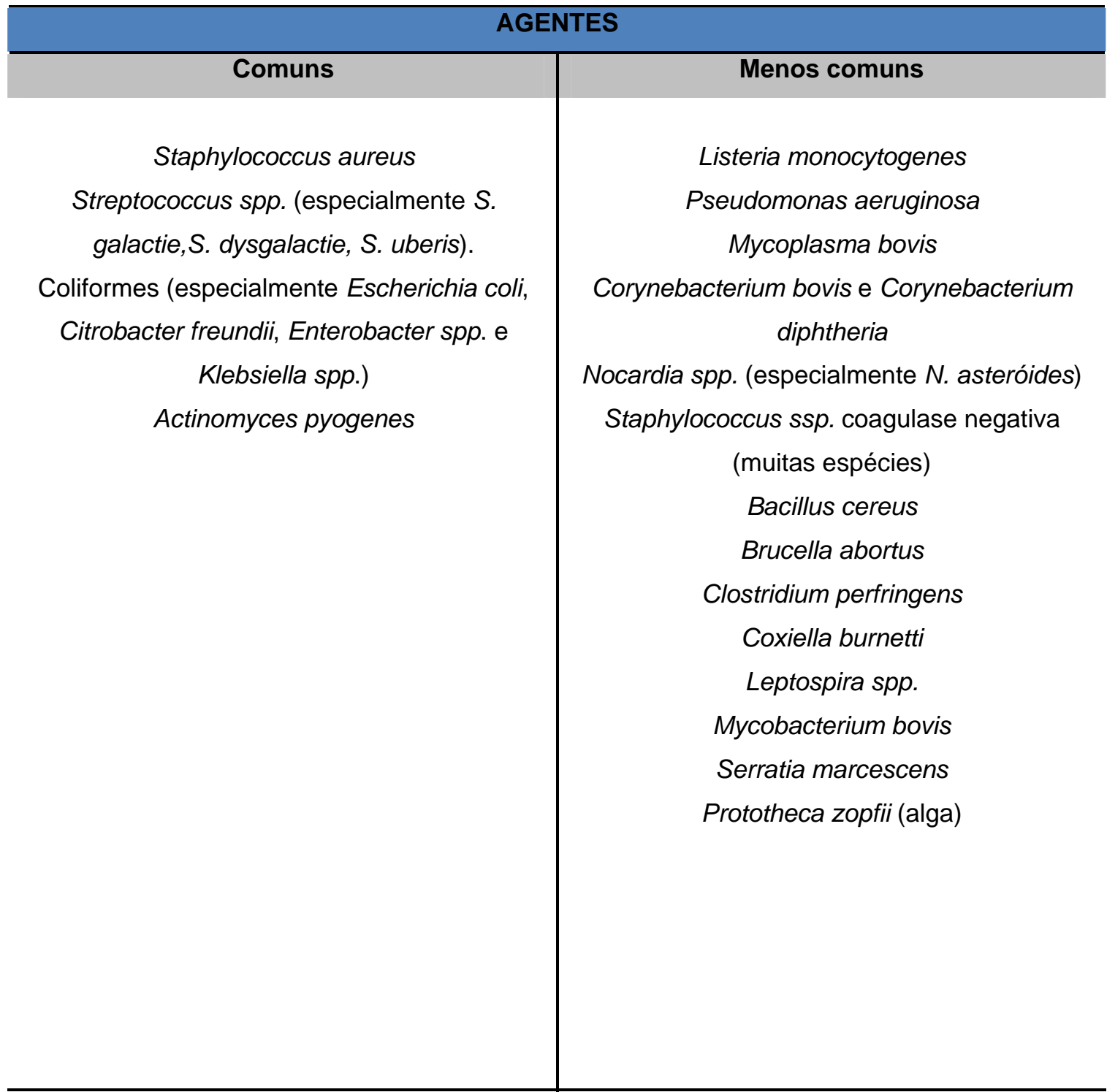

Fonte: MARTH e STEELE, 2001 
Nossos resultados evidenciaram ações tanto em Staphylococcus aureus como em Micrococcus luteus o que nos faz pensar que o muco do escargot pode vir a ser um biofarmaco de amplo espectro de ação. Este dado vai de encontro com os achados de Ogawa (1999), uma vez, que este pesquisador e seus colaboradores coloram que o muco do escargot africano apresenta ação bactericida para diversas espécies bacterianas, entre elas o Staphylococcus aureus, porém discorda do mesmo, pois em seus estudos não foram evidenciadas ações em o Micrococcus luteus na fase de crescimento. Assim acreditamos que esse achado possa em muito contribuir para futuras pesquisas desenvolvidas em nosso laboratório utilizando o muco de escargot em reparo tecidual, uma vez que este microrganismo faz parte da microbiota natural da pele, ainda, podemos inferir que aqui, que esta ação pode estar relacionada à utilização do muco puro sem a diluição, somado ao tempo de ação de aproximadamente 30 minutos, que ao nosso ver, potencializa o efeito bactericida. Desta forma estes resultados sinalizam para o muco de escargot como agente preventivo ou até mesmo, possível antiséptico no pré e pós dipping para tratamentos das infecções da glândula mamária ou até mesmo para as afecções da pele, como feridas, escaras e cicatrizes (CAETANO, 1998).

Nossos estudos são embriogênicos, ainda nossa casuística refere-se à pequena quantidade de muco extraída, o que atualmente inviabiliza o uso comercial, porém esta pesquisa, permeia vários campos de atuação, o que nos deixa bastante entusiasmados com a possibilidade de expansão e desenvolvimento de novas técnicas e alternativas de uso até poder ser sintetizado comercialmente. 


\section{CONCLUSÃO}

1. A população microbiana da mucosa dos tetos não varia conforme a sua posição no úbere do animal, devendo se tomar o mesmo cuidado independente do seu posicionamento, anterior ou posterior.

2. A técnica utilizada neste trabalho para o isolamento mostrou-se bastante eficiente e simples para a identificação do microorganismo predominante, onde neste trabalho foram identificados: Staphylococcus aureus, Micrococcus luteus, Klebsiella pneumoniae e Acinetobacter junii.

3. O muco de escargot, independente da espécie estudada (Achatina fulica e Achatina monocromatica monocromatica) apresentaram-se tão eficazes no controle de crescimento bacteriano quanto o iodo (200 ppm), podendo ser até mesmo um produto alternativo no controle e prevenção de mastite em vacas leiteiras.

4. A textura dos tetos tratados com o muco apresentava-se macios e com aspecto bastante hidratado, quando comparados ao iodo.

5. Estudos e pesquisas aplicadas ao controle e tratamento da mastite bovina fazendo uso do muco de escargot Achatina sp necessitam de continuidade e desenvolvimento, de maneira a possibilitar a adoção desse tipo de tratamento nos animais de pecuária leiteira de maneira economicamente viável e eficiente. 


\section{REFERÊNCIAS}

ALBERTON, L. R.; WERNER, P. R.; CUNHA, L.; WARTH, J. F.; FARACO, A. P. P. A.; RIBAS, N. P. Vacinação com bacterina de Staphilococcus aureus no controle da mastite em vacas em lactação. Arquivo de Ciências Veterinárias e Zoologia UNIPAR, Paraná, 2001, v. 4, n. 1, p. 31-40.

ALMEIDA, L. A. B.; BENITES, N. R. Avaliação do tratamento alopático e homeopático de mastite bovina em animais inoculados com Staphilococcus aureus. 2004. p.104. Dissertação (Mestrado em Medicina Veterinária) - Faculdade de Medicina Veterinária e Zootecnia, Universidade de São Paulo, São Paulo, 2004.

ALMEIDA, A. C.; FONSECA, Y. M.; SOARES, T. M. P.; SILVA, D. B.; BUELTA, T. T. M.; SILVA, G. L. M. E.Tratamento de Mastite Subclinica em Bovinos utilizando Bioterapia. Revista Universidade de Alfenas. Alfenas, v.4 , n. 5, p.199-203,1999.

AMARAL, L. A.; ISA, H.; DIAS, L. T.; ROSSI TR., O. D.; FILHO, A. N. Avaliação da eficácia da desinfecção de teteiras e dos tetos no processo de ordenha mecânica de vacas. Pesquisa Veterinária Brasileira. Rio de Janeiro, v. 24, n. 4., p.173-177, 2004.

ATLAS, R. M. Handbook of microbiological media for the examination of foods. 2. ed., Florida: CRC press, 2006. p 49-306.

BELL, C.; NEAVES, P.; WILLIAMS, A. P. Convensional methods II: microbiological examination of samples. food microbiology and laboratory pratice, 2005. p. 231-233.

BISWAS, C.; SINHA, D.; MANDAL, C. Investigation on interaction of Achatinin, a 9-0-acetyl sialic acid-binding lectin, with lipopolysaccharide in the innate immunity of Achatina fulica snails. Molecular_Immunology, v. 37, n. 12-13, p. 745-754, 2000.

BRENNER, D. J.; KRIEG, N. R.; STANLEY, J. T.; GARRITY, G. M. Bergey's manual of systematic bacteriology. 2. ed. New York: Lippincott Willians \& Wilkins, 2005. v. 1 e 2.

BLOOD, D. C.; RADOSTITIS, O. M. Veterinary medicine. 7. ed. London: Baillière Tindall, 1991. p. 501-559.

BLOWEY, R.; EDMONDSON, P. Control de la mastitis en granjas de vacuno de Leche. Zaragoza: Acribia, 1999. p. 208.

BRITO, M. A. V. P. Resíduos de antibióticos no leite: um problema que tem solução. Jornal do leite. Embrapa. Gado de Leite, v. 5, n. 16, p. 3, 2001.

BRITO, J. R. F.; BRITO, M. A. V. P.; VERNEQUE, R. S. Contagem bacteriana da superfície de tetas de vacas submetidas a diferentes processos de 
higienização incluindo a ordenha manual com participação do bezerro para estimular a descida do leite. Ciência Rural, Santa Maria, v. 30, n. 5, p. 847850, 2000.

CAETANO, F. A. M. Utilização da secreção do muco do escargot Achatina fulica no processo cicatricial. 1998. 61 f. TCC (Graduação em Medicina Veterinária) - Faculdade de Medicina Veterinária, Fundação Educacional Octávio Bastos, São João da Boa Vista, 1998.

COSTA, E. O. Importância da mastite na produção leiteira do país. Revista de educação continuada do CRMV-SP. São Paulo, v.1, p. 3-9, 1998.

COSTA, E. O.; RIBEIRO, A. R.; WATANABE, E. T.; SILVA, J. A. B.; GARINO, J. R.; BENITES, N. R.; HORIUTI, A. M. Mastite subclinica: prejuízos causados e os custos de prevenção em propriedades leiteiras. NAPGAMA. São Paulo, v. 2, n. 2, p.16-20, 1999.

COTTREL, J. M.; HENDERSON, I. F.; WRIGHT, D. J. Studies on the glycosaminoglycan component of trail mucus from the terrestrial slug, Arion ater L. Comparative Biochemical Physiology, v. 107B, p. 285-296, 1994.

DHARMU, I.; RAMAMURTY, N.; KANNAN, R.; BABU, M. Cytotoxic effect of achatinin $_{H}$ (lectin) from Achatina fulica against a human mammary carcinoma cell line (MCF7). Vitro Cellular \& Developmental Biology - Animal, v. 43, n. 8/9, p. 306-314, 2007.

DOMINGUES, P. F.; LANGONI, H. Manejo sanitário animal. Rio de Janeiro: EPUB, 2001.

EHARA, T.; KITAJIMA, S.; KANZAWA, T.; TSUCHIYA, T. Antimicrobial action of achacin is mediated by L-amino acid oxidase activity. FEBS letters 531, v.3 , n.531 , p. 509-512, 2002.

CARNEIRO, D. M. V. C. Efeito do uso de um selante interno de tetos na profilaxia de novas infecções intramamárias durante o período seco e no pós-parto.Trabalho de dissertação de mestrado. 2006. 75 f. Dissertação (Mestrado em Ciências Veterinárias) - Universidade do Estado de Santa Catarina, Lage, Santa Catarina, 2006.

FORRET, C.; AGUERO, H.; JANOWICZ, P. Efficacy of Two barrier iodine teat dips under natural exposure conditions. American Dairy Science Association, v.6, n.89, p. 2279-2285, 2006.

FUCHINO, H. O.; WATANBE, Y.; HIRAKAWA, C.; TAMIYA, T.; MATSUMOTO, J. J.; TSUCHIYA, T.; Bactericidal action of a glycoprotein from the body surface mucus of giant afrcan snail. Comparative Biochemical Physiology, Tokio, v.101C, n. 3, p. 607-613, 1992.

GALO, G. El caracol: cria y explotacion. 2. ed. Madrid: Ediciones Mundiprensa, 1984. 179 p. 
GALTON, D. M.; PETERSON, L. G.; MERRILL, W. G. Effects of premilking udder preparations practices on bacterial counts in milk and on teats. Journal Dairy Science, v. 69, p. 2060-266, 1986.

GALTON, D. M.; PETERSON, L. G. MERRILL, W. G. Evoluation of udder preparations on intramammary infections. Journal Dairy Science, v.71, n.5, p. 1417-1421, 1988.

GOMOT, A. Effets de méteaux lourds sur le development des escargots. Utilisation des escargots comme bio-indicateurs de pollution per les métaux lourds pour la preservation de la santé de l'homme. Bulletin de l'Académie de Médicine, France, v.181, n. 1, p. 59-75, 1997.

HOLT, J. G.; KRIEG, N. R.; SNEATH, P. H. A.; STANLEY, J. T.; WILLIAMS, S. T. Bergey's manual of determinative bacteriology. 9. ed. New York: Lippincott Willians \& Wilkins, 2000.

IGUCHI, S. M. M.; AIKAWA, T.; MATSUMOTO, J. J. Antibacterial activity of snail mucus mucin. Comparative Biochemical Physiology, v. 72A, n. 3, p. 571-574, 1982.

IGUCHI, S. M. M.; MOMOI, T.; EGAWA, K.; Matsumoto, J. J. An NAcetylneuraminic acid-specific lectin from the body surface mucus of African giant snail. Comparative Biochemical Physiology, v. 81B, n. 4, p. 897-900, 1985.

IYOMASA, M.; MARTINS, M. P.; PACHECO, P.; MIZUSAKI, C.; FIGUEIREDO, L. D.; SIRIO, O. J.; CAETANO, F. A. M. Evolution of the Achatina fulica snail glycoproteic mucus in surgical injury of rabbits. Brazilian journal of morphological Scienes, v. 18, n. 2, p.149, 2002.

JEONG, J.; TOIDA, T.; MUNETA, Y.; KOSIISHI, I.; IMANARI, T.; LINHARDT, R. J.; CHOI, H. S.; WU, S. J.; KIM,Y. S. Localization and characterization of acharan sulfate in the body of the giant African snail Achatina fulica. Comparative Biochemistry and Physiology, v. 130B, p. 513-519, 2001.

JÚNIOR, I. A. N.; falta sobrenome do autor A. NADER FILHO, A. N.; OLIVEIRA, J. A. Sensibilidade e especificidade do CAlifornia Mastitis Test (CMT) e da Condutividade Elétrica do Leite (CEL) de vacas durante a lactação. ARS Veterinaria. Jaboticabal, v. 22, n. 2, p. 135-137, 2006.

KIM, H. S.; LEE, Y. H.; LEE, Y. R.; IM, S. A.; LEE, J. K.; KIM, Y. S.; SIM, J. S.; $\mathrm{CHOI}, \mathrm{H}$. S.; LEE, C. K. Activation of professional antigen presenting cells by acharan sulfate isolated from giant african snail, Achatina fulica. Archives of Pharmacal Research, Seoul, v. 30, n. 7, p. 866-870, 2007.

KIM, Y. S.; JO, Y. Y.; CHANG, I. M.; TOIDA, T.; PARK, Y.; LINHARDT, R. J. A New Glycosaminoglycan from the giant African snail Achatina fulica. Journal Biology Chemical, v. 271, p.11750-11755, 1996. 
KUBOTA, Y.; WATANABE, Y.; OTSUKA, H.; TAMIYA, T.; TSUCHIYA, T.; MATSUMOTO, S. S. Purification and caracterization of an antibacterial factor from snail mucus.Comparative Biochemistry and Physiology, Tokio, v. 82c, n. 2, p. 345-348, 1985.

LANGONI, H. Mastite bovina: conceitos e fundamentos. In: ENCONTRO DE PESQUISADORES EM MASTITES, 2007. Botucatu, Anais... Botucatu: UNESP, 2007, p. 08-17.

LORENZI, A. T.; MARTINS, M. F. Análise colorimétrica e espectroscópica do muco de caracóis terrestres Achatina sp alimentados com ração diferenciada. Revista Brasileira de Zootecnia, v. 37, n. 3, p. 572-579, 2008.

MARTH, E. H.; STEELE, J. L. Applied dairy microbiology. 2. ed. New York: Marcel Dekker, 2001.

MARTINS, M. F.; CAETANO, F. A. M.; SÍRIO, O. J.; YIOMASA, M. M.; MIZUSAKI, C. I.; FIGUEIREDO, L. D.; PACHECO, P. Avaliação macro e microscópica da cicatrização de lesões experimentalmente provocadas em pele de coelhos tratadas com secreção mucoglicoproteica do escargot Achatina fulica. Brazilian Journal of Veterinary Research and Animal Science, São Paulo, v. 40, p. 213-218, 2003.

MENDONÇA, L. C. Viabilidade do controle da mastite contagiosa e da utilização do escore de sujidade de ubere e de lesões de esfíncter de tetos no monitoramento do risco de ocorrência da doença, 2008. 42 f. Dissertação (Mestre em Ciência Animal) - Escola de Veterinária, Universidade Federal de Minas Gerais, Belo Horizonte, 2008.

OGAWA, M.; NAKAMURA, S.; ATSUCHI, T.; TAMIYA, T.; TSUCHIYA, T.; NAKAI, S. Macromolecular antimicrobial glycoprotein, achacin, expressed in a methylotrophic yeast Pichia pastoris. FEBS Lett. v. 448, p. 41-44, 1999.

PACHECO, P.; MARTINS, M.F. Desempenho ponderal do escargot Achatina $s p$ frente a diferentes formulações de ração. Anais Congresso Brasileiro Medicina Veterinária Goiânia, v.8, p. 184, 1996.

PANKEY, J. W. Premilking udder hygiene. Journal of Dairy Science, v. 72, n. 5, p. 1308-1312, 1989.

PEDRINI, S. C. B.; MARGATHO, L. F. F. Sensibilidade de microorganismos patogênicos isolados de casos de mastite clinica em bovinos frente a diferentes tipos de desinfetantes. Arquivos do Instituto Biológico. São Paulo, v. 70, n. 4, p.391-395, 2003.

POZETTI, G. L. Medicamentos homeopáticos: algumas monografias. Ribeirão Preto: Instituto François Lamasson, 1988. 100 p. 
RANGEL, P. M. Perfil genético e microbiológico de cepas de Escherichia coli isoladas de leite mastítico bovino. Jaboticabal: UNESP, 2007.

RUIZ, R.L.Microbiologia Zootécnica. 1. ed.São Paulo: Roca,1992.

RUPPERT, E. E.; BARNES, R. D. Zoologia dos invertebrados. 6. ed. São Paulo: Roca, 1996. p. 332-352.

SANTOS, M. V. Biossegurança aplicada ao controle de mastite. Balde Branco, São Paulo, v. 463, p. 62-65, 2003.

SANTOS, M. V.; FONSECA, L. F. L. Estratégias para controle de mastite e melhoria na qualidade do leite. Barueri: Manole, 2007.

SHALM, O. W.; NOORLANDER, D. O. Experimental and observation leading to development of California Mastits Test. Journal of the American Veterinary Medical Association, v. 130, p.199-204, 1957.

SIMKISS, K.; WILBUR, K. M. The molluscan epidermis and its secretions. Symposia of the Zoological Society of London, v. 39, p. 35-76, 1977.

SIRIO, O. J. Verificação da potencialização do efeito cicatrizante do muco dos caracóis do gênero Achatina promovida por dieta á base de confrei. 2005. 87 f. Dissertação (Mestrado em Medicina Veterinária) - Faculdade de Medicina Veterinária e Zootecnia, Universidade de São Paulo, Pirassununga, 2005.

SPENBER, W. A.; MOORMAN, M. A.; FREIER, T. A. Cultural methods for the enrichment and isolation of microorganisms. Compendium of Methods for the Microbiological Examination of Foods, 4. ed. Washington, D.C.: American Public Health Association, 2001. Cap. 5, p. 45-51.

VANNIER, L.; POIRIER, J. Tratado de matéria homeopática. 9. ed. Falta local: Organização Andrei, 1987. 89 p.

VANSIL, M.; VENGLOVSKY, J. Reduction of mastits ocurrence in a dairy cow herd using combined anti-mastitis methods. In: INTERNATIONAL CONGRESS IN ANIMAL HYGIENE. 9., 1997, Helsinki: University of Helsinki, Departament of Clinical Veterinary Science, Section of Animal Higyiene. 1997. v.1, p.159162.

WEINNER, P.J. Microbiology of dairy animals. In: MARTH, E. H.; STEELE, I. L. (Ed.). "Aplied dairy microbiology". 2. ed. New York: Marcel Dekker, 2001. 


\section{Anexo A}

\section{Questionário com os Produtores Leme e Região}

\section{PROPRIEDADE 1}

Nome da Propriedade: Faz. Santa Maria da Boa Vista

Localização: Leme

Área: 180 hectares

Atividades da propriedade: Bovinocultura de leite, bovinocultura de corte, cultura canavieira, silvicultura

\section{Dados da Bovinocultura de leite:}

Numero total de animais: 47 animais

Raça predominante: jersey

Animais em Lactação: 13 vacas

Uso de reprodutor: ( ) sim (X) não ( ) outros

Produção diária: 235 litros

Destino do leite: Laticinio

Realiza pré dipping ( )Sim (X ) Não

Realiza pos dipping (X )Sim ( ) Não

Realiza teste de mastite como:

Teste de Tamis (caneca de fundo preto)

(X )Sim

( )Não

CMT (California Mastits Test)

( ) Sim

( X)Não

Possui recentemente casos de mastite ( uma semana)?

( ) sim

( X) não

Utiliza antibiótico na secagem do animal?

(X) $\operatorname{sim}$

( ) não

Tipo de ordenha:

( ) Manual

(X) Mecânica: (X ) Balde ao pé

( ) Espinha de peixe 


$$
\text { ( ) outro }
$$

Sistema de ordenha:

( ) Com bezerro ao pé

( X) Sem bezerro ao pé

Numero de ordenhas:

( ) Uma
(X) Duas
( ) Três
( ) Mais Quantas?

Possui Tanque de expansão:

( X) Sim

( ) Não

A atividade é a principal fonte de renda:

( )Sim

( X)Não

Quantos trabalham na atividade:

2 pessoas

Alimentação é fornecida

( ) Antes da ordenha

(X ) Durante a ordenha

( ) Após a ordenha

PROPRIEDADE 2:

Nome da Propriedade: Sitio Boa Vista de Leme

Localização: Leme

Área: 56 hectares

Atividades da propriedade: Bovinocultura de leite, bovinocultura de corte, ovinocultura, avicultura.

\section{Dados da Bovinocultura de leite:}

Numero total de animais: 32 animais

Raça predominante: Girolando

Animais em Lactação: 10 vacas

Uso de reprodutor: ( ) sim ( ) não ( X) outros

Utiliza-se inseminação e monta natural

Produção diária: 100 litros

Destino do leite: Laticinio

Realiza pré dipping ( ) Sim (X ) Não

Realiza pos dipping (X )Sim ( ) Não

Realiza teste de mastite como:

Teste de Tamis (caneca de fundo preto)

( )Sim

( )Não

CMT (California Mastits Test)

( )Sim

( )Não

Possui recentemente casos de mastite ( uma semana)?

(X) sim Quantos? Três 
( ) não

Utiliza antibiótico na secagem do animal?

( ) sim

( $\mathrm{X}$ ) não

Tipo de ordenha:

( ) Manual

( X) Mecânica: (X ) Balde ao pé

( ) Espinha de peixe

( ) outro

Sistema de ordenha:

( X)Com bezerro

( ) Sem bezerro

Numero de ordenhas:

( ) Uma

(X) Duas

( ) Três

( ) Mais Quantas?

Possui Tanque de expansão:

( X) Sim

( ) Não

A atividade é a principal fonte de renda:

( X)Sim

( )Não

Quantos trabalham na atividade:

2 pessoas

Alimentação é fornecida:

( ) Antes da ordenha

( ) Durante a ordenha

(X) Após a ordenha

Após a ordenha é fornecida o volumoso e a ração farelada (Concentrado)

\section{PROPRIEDADE 3}

Nome da Propriedade: Fazenda Arizona

Localização: Leme

Área: 200 hectares

Atividades da propriedade:Citricultura, bovinocultura de leite, ovinocultura, cultura canavieira.

\section{Dados da Bovinocultura de leite:}

Numero total de animais: 32 animais

Raça predominante: Gir leiteiro

Animais em Lactação: 19 vacas

Uso de reprodutor: ( ) sim (X) não ( ) outros

Produção diária: 180 litros

Destino do leite: Laticinio

Realiza pré dipping ( ) Sim (X ) Não

Realiza pos dipping ( )Sim ( X ) Não

Realiza teste de mastite como: 
Teste de Tamis (caneca de fundo preto)

(X) Sim

( )Não

CMT (California Mastits Test)

( )Sim

(X)Não

Possui recentemente casos de mastite ( uma semana)?

( X) sim Quantos? Dois

( ) não

Utiliza antibiótico na secagem do animal?

( ) $\operatorname{sim}$

(X) não

Tipo de ordenha:

( ) Manual

( X) Mecânica: (X ) Balde ao pé

( ) Espinha de peixe

( ) outro

Sistema de ordenha:

( X)Com bezerro

( ) Sem bezerro

Numero de ordenhas:

( ) Uma

(X) Duas

( ) Três

( ) Mais Quantas?

Possui Tanque de expansão:

( X) Sim

( ) Não

A atividade é a principal fonte de renda:

( )Sim

( X)Não

Quantos trabalham na atividade:

2 pessoas

Alimentação é fornecida:

( ) Antes da ordenha

(X ) Durante a ordenha

( ) Após a ordenha 


\section{ANEXO B}

\section{COMPOSIÇÃO DOS MEIOS DE CULTURA UTILIZADOS}




\section{ANEXO 2}

\section{Meio Agar MacConkey}

\section{Composição em g/L:}

Digestão peptídica de tecido animal: 20.00

Lactose: 10.00

Sais Biliares: 5.00

Cloreto de Sódio: 5.00

Vermelho Neutro: 0.07

Agar: 15.30

pH Final (a $\left.25^{\circ} \mathrm{C}\right): 7.4 \pm 0.2$

\section{Procedimento de Preparação do Meio de Cultura:}

Dissolva 55.37 gramas em $1000 \mathrm{ml}$ de água destilada. Aqueça até ferver agitando levemente para dissolver completamente o Agar. Esterilizar autoclavando a 15lbs de pressão a $121^{\circ} \mathrm{C}$ por 15 minutos. Evitar o superaquecimento. Esfriar para $45-50^{\circ} \mathrm{C}$ e colocar em placas de Petri estéreis. A superfície do meio deverá estar seca quando inoculado.

\section{Plate Count Agar (PCA)}

\section{Composição em g/L:}

Caseína enzimática hidrolisada: 5.00

Extrato de Levedura: 2.50

Dextrose: 1.00

Agar: 9.00

pH Final $\left(\mathbf{a} 25^{\circ} \mathrm{C}\right): 7.0 \pm 0.2$

Procedimento de Preparação do Meio de Cultura:

Dissolva 17.5 gramas em $1000 \mathrm{ml}$ de água destilada. Ferva para dissolver o meio completamente. Esterilizar autoclavando a $15 \mathrm{lbs}$ de pressão a $121^{\circ} \mathrm{C}$ por 15 minutos.

\section{Agar Baird Parker Base}

\section{Composição em g/L:}

Caseína enzimática hidrolisada: 10.00

Extrato de Carne: 5.00 
Extrato de Levedura: 1.00

Glicina: 12.00

Piruvato de Sódio: 12.00

Cloreto de Lítio: 5.00

Agar: 20.0

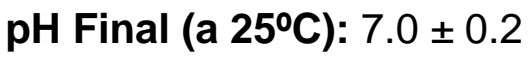

Procedimento de Preparação do Meio de Cultura:

Dissolva 63 gramas em 950ml de água destilada. Aqueça para dissolver o meio completamente. Esterilize autoclavando a $15 \mathrm{lbs}$ de pressão a $121^{\circ} \mathrm{C}$ por 15 minutos. Resfrie a $50^{\circ} \mathrm{C}$ e adicione assepticamente $50 \mathrm{ml}$ de Emulsão de Gema de Ovo concentrado (FD045) e 3ml de solução Telurito de Potássio 3.5\% estéril (FD047) ou 50ml de Emulsão Telurito Gema de Ovo (FD046). Misturar bem e despejar em placas de Petri.

\section{Agar Sabouraud Dextrose}

Composição em g/L:

Peptona (carne e caseína): 10.00

Glicose monoidratada: 40.00

Agar: 15.00

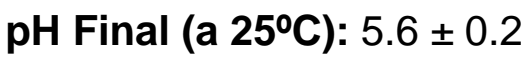

Procedimento de Preparação do Meio de Cultura:

Dissolva 61.37 gramas em 1000ml de água destilada/purificada. Ferva para dissolver o meio completamente. Esterilize autoclavando a $15 \mathrm{lbs}$ de pressão a $121^{\circ} \mathrm{C}$ por 15 minutos.

Fonte: Laboratório Himedia. 


\section{Anexo C}

\section{Relatório Técnico Análise Microbiológica (OS B 090032)}

Apresentado por: Coleção de CulturasTropical Fundação André Tosello 
Coleção de Culturas Tropical www.cct.org.br

Fundação André Tosello www.fat.org.br

R. Latino Coelho, 1301 Pq. Taquaral

CEP 13087-010 Campinas SP

Fone/Fax: (19) 3242-7022

Fax: (19) 3242-7827

CNPJ 46.126.322/0001-82

\title{
Relatório Técnico
}

\section{Análise Microbiológica}

(OS B 090032)

\author{
Apresentado a: Sr. Eugenio Yokoya
}

Apresentado por: Coleção de Culturas Tropical Fundação André Tosello

Novembro 2009 
Coleção de Culturas Tropical www.cct.org.br
Fundação André Tosello www.fat.org.br

R. Latino Coelho, 1301 Pq. Taquaral CEP 13087-010 Campinas SP

Fone/Fax: (19) 3242-7022

Fax: (19) 3242-7827

CNPJ 46.126.322/0001-82

\section{Relatório Técnico final}

Serviço: Identificação de microrganismos

Interessado: Eugenio Yokoya

Endereço: UNP- USP Pirassununga - Fazenda Santa Maria da Boa Vista s/n C.P 199 Bairro Areial Leme - SP CEP 13.610-970
Relatório: B 090032

Data de Recebimento: 17/09/2009

\begin{tabular}{|l|l|}
\hline \multicolumn{1}{|c|}{ Serviço No. } & Descrição da Amostra \\
\hline B 090032-1 & Amostra $n^{\circ} 2$. \\
\hline B 090032-2 & Amostra $n^{\circ}$ 3. \\
\hline B 090032-3 & Amostra $n^{\circ} 4$. \\
\hline B 090032-4 & Amostra $n^{\circ}$ 6. Colônia amarelo-ouro. \\
\hline B 090032-5 & Amostra $n^{\circ}$ 10. Colônia amarelo-ouro. \\
\hline B 090032-6 & Amostra $n^{\circ}$ 13. Colônia amarelo-ouro. \\
\hline B 090032-7 & Amostra $n^{\circ}$ 32. Colônia branca \\
\hline B 090032-8 & Amostra $n^{\circ} 29$. \\
\hline OBS & Amostras chegaram isoladas. \\
\hline
\end{tabular}

\section{Objetivos:}

Identificação de microrganismos por taxonomia convencional

\section{Metodologia utilizada:}

Taxonomia clássica convencional.

Avaliação de características fisiológicas e metabolismo bioquímico pela taxonomia clássica convencional, associada a sistema de testes rápidos de identificação.

A identificação é baseada na análise comparativa de características diferenciais de morfologia, fisiologia e metabolismo bioquímico da linhagem teste com dados citados na literatura de referência. 
Coleção de Culturas Tropical www.cct.org.br
Fundação André Tosello www.fat.org.br

R. Latino Coelho, 1301 Pq. Taquaral

CEP 13087-010 Campinas SP

Fone/Fax: (19) 3242-7022

Fax: (19) 3242-7827

CNPJ 46.126.322/0001-82

3. Resultados do isolamento

\begin{tabular}{|l|l|l|}
\hline Serviço No. & \multicolumn{1}{|c|}{ Amostra } & \multicolumn{1}{|c|}{ Resultados } \\
\hline B 090032-1 & Amostra $n^{\circ} 2$. & Colônia branca, elevada, circular, regular, brilhante \\
\hline B 090032-2 & Amostra $n^{\circ} 3$. & Colônia branca, elevada, circular, regular, brilhante \\
\hline B 090032-3 & Amostra $n^{\circ} 4$. & Colônia amarela, lisa, plana, irregular, opaca \\
\hline B 090032-4 & $\begin{array}{l}\text { Amostra } n^{\circ} \text { 6. Colônia amarelo- } \\
\text { ouro. }\end{array}$ & Colônia amarela, lisa, plana, regular, circular, opaca \\
\hline B 090032-5 & $\begin{array}{l}\text { Amostra } n^{\circ} \text { 10. Colônia amarelo- } \\
\text { ouro. }\end{array}$ & Colônia amarela, lisa, plana, regular, circular, opaca \\
\hline B 090032-6 & $\begin{array}{l}\text { Amostra } n^{\circ} \text { 13. Colônia amarelo- } \\
\text { ouro. }\end{array}$ & Colônia amarela, lisa, plana, regular, circular, opaca \\
\hline B 090032-7 & $\begin{array}{l}\text { Amostra } n^{\circ} \text { 32. Colônia branca } \\
\text { B 090032-8 }\end{array}$ & $\begin{array}{l}\text { Colônia branca leitosa, elevada, regular, circular, } \\
\text { brilhante }\end{array}$ \\
\hline
\end{tabular}

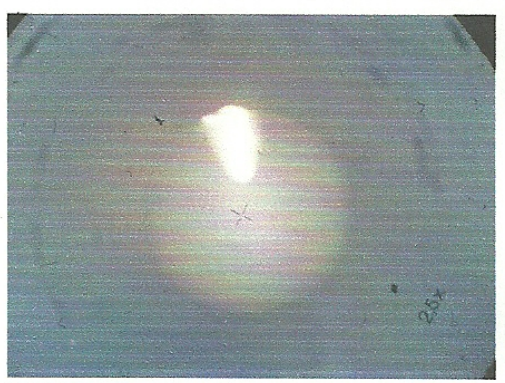

32-1 - K.pneumoniae

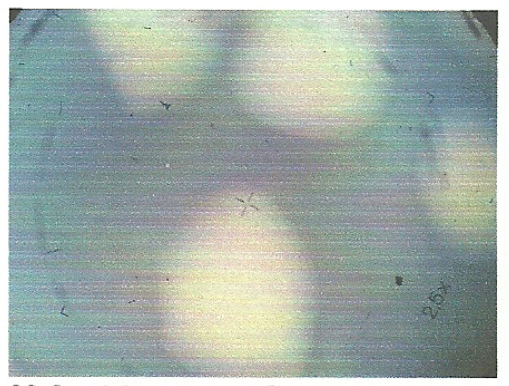

32-3 - Micrococcus luteus

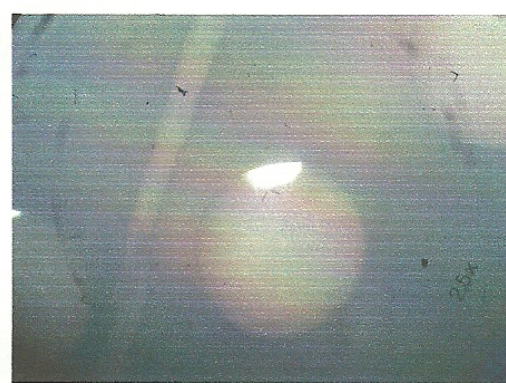

32-2-Acinetobacter junii

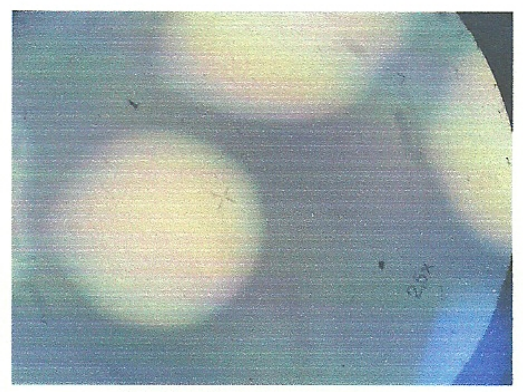

32-4-S. aureus 
Coleção de Culturas Tropical www.cct.org.br
Fundação André Tosello www. fat.org.br

R. Latino Coelho, 1301 Pq. Taquaral CEP 13087-010 Campinas SP

Fone/Fax: (19) 3242-7022

Fax: (19) 3242-7827

CNPJ 46.126.322/0001-82

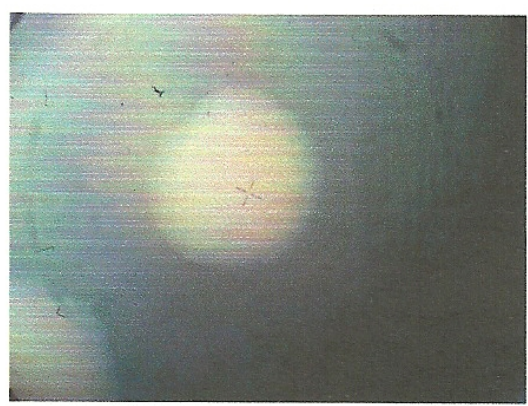

32-5 - S. aureus

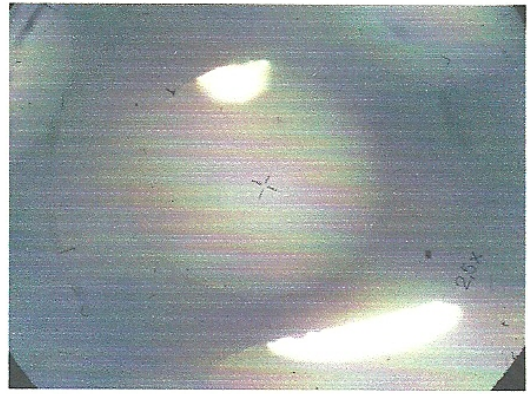

32-7 - K.pneumoniae

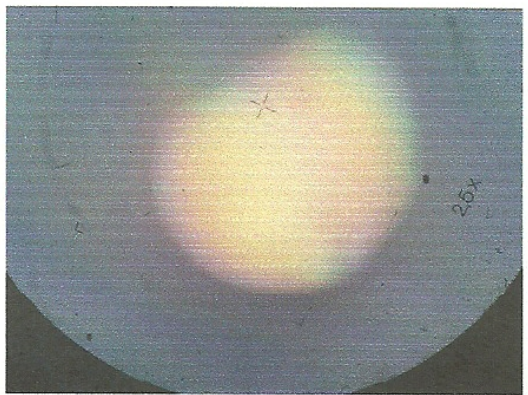

36-6-S. aureus

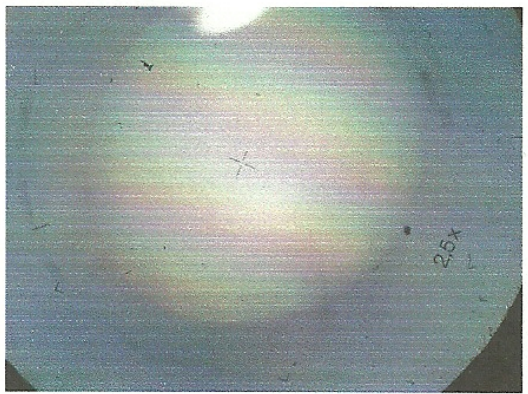

32-8 - K.pneumoniae

4. Resultados da identificação

\begin{tabular}{|c|c|c|}
\hline Serviço No. & Amostra & Resultados \\
\hline В 090032-1 & Amostra $n^{\circ} 2$ & Klebsiella pneumoniae (Schroeter 1886) Trevisan 1887 \\
\hline B 090032-2 & Amostra $n^{\circ} 3$ & $\begin{array}{l}\text { Acinetobacter junii Bouvet and Grimont } 1986 \\
\text { Synonym: Acinetobacter grimontii }\end{array}$ \\
\hline B 090032-3 & Amostra $n^{\circ} 4$ & $\begin{array}{l}\text { Micrococcus luteus (Schroeter 1872) Cohn } 1872 \\
\text { emend. Wieser et al. 2002. Sinônimo: "Micrococcus } \\
\text { lysodeikticus", "Sarcina citrea", "Sarcina flava", } \\
\text { "Sarcina lutea" }\end{array}$ \\
\hline B 090032-4 & $\begin{array}{l}\text { Amostra } n^{\circ} 6 \text {. Colônia amarelo- } \\
\text { ouro. }\end{array}$ & Staphylococcus aureus De La Fuente et al. 1985 \\
\hline B $090032-5$ & $\begin{array}{l}\begin{array}{l}\text { Amostra } \mathrm{n}^{\circ} \\
\text { amarelo-ouro. }\end{array} \\
\end{array}$ & Staphylococcus aureus De La Fuente et al. 1985 \\
\hline B 090032-6 & $\begin{array}{l}\begin{array}{l}\text { Amostra } n^{\circ} \\
\text { amarelo-ouro. }\end{array} \\
\text { 13. Colônia }\end{array}$ & Staphylococcus aureus De La Fuente et al. 1985 \\
\hline B 090032-7 & Amostra $n^{\circ} 32$. Colônia branca & Klelbsiella pneumoniae (Schroeter 1886) Trevisan 1887 \\
\hline B 090032-8 & Amostra $n^{\circ} 29$ & Klebsiella pneumoniae (Schroeter 1886) Trevisan 1887 \\
\hline
\end{tabular}


Coleção de Culturas Tropical www.cct.org.br
Fundação André Tosello www. fat.org.br

R. Latino Coelho, 1301 Pq. Taquaral CEP 13087-010 Campinas SP Fone/Fax: (19) 3242-7022 Fax: (19) 3242-7827 CNPJ 46.126.322/0001-82

Referência Bibliográfica:

DSMZ - Deutsche Sammlung von Mikroorganismen und Zellkulturen disponivel em: http://unww.dsmz.del

HOLT J.G., et al. Bergey's manual of determinative bacteriology. $9^{\text {th }}$ ed. The Williams \& Wilkins, Baltimore, 1994.

SNEATH, P.H. ${ }^{\text {a }}$ Endospore-forming Gram positive rods and cocci. In: Sneath P.H.; Mair, N.S.; Sharpe, M.E. and Holt, J.G. Bergey's Manual of Systematic Bacteriology. Baltimore: Williams \& Wilkins, 1986. Vol.2.

BRENNER, D.J. Facultatively Anaerobic Gram Negative Rods In: KRIEG, N.R.; HOLT, J.G. (Eds.). Bergey's Manual of Systematic Bacteriology. $9^{\text {th }}$ ed. Baltimore: Williams \& Wilkins, 1984. Vol.1.

SCHLEIFER, K.H. Gram Positive Cocci In: Sneath P.H. ${ }^{\text {; }}$ Mair, N.S.; Sharpe, M.E. and Holt, J.G. Bergey's Manual of Systematic Bacteriology. Baltimore: Williams \& Wilkins, 1986. Vol.2,.

KONEMAN, E.W; ALLEN, S.D.; JANDA,W.M.; SCHRECKENBERGER,P.C.; WINN JR, W.C. Diagnostic Microbiology, JB Lippincott Company, $4^{\text {a }}$ edition, 1992

Observações: As análises de identificação de bactérias foram realizadas nos laboratórios da Coleção de Culturas Tropical, Fundação André Tosello. Os resultados têm significação restrita e se aplicam somente às culturas recebidas para análise. 
Coleção de Culturas Tropical www.cct.org.br
Fundação André Tosello www.fat.org.br

R. Latino Coelho, 1301 Pq. Taquaral

CEP 13087-010 Campinas SP

Fone/Fax: (19) 3242-7022

Fax: (19) 3242-7827

CNPJ 46.126.322/0001-82

\section{FICHA DE IDENTIFICAÇÃO}

\begin{tabular}{|c|c|c|c|}
\hline \multicolumn{2}{|c|}{ Característica da Colônia } & \multicolumn{2}{c|}{ Característica da Célula } \\
\hline Cor & Branca & Forma & Bastonete pequeno \\
\hline Forma & Elevada, circular & Gram & Negativo \\
\hline Margem & Regular & Rearranjo & Isolados e lado a lado \\
\hline Superfície & Lisa & Móveis & Negativo \\
\hline Textura & Cremosa & Requerimento de Oxigênio & Anaeróbio facultativo \\
\hline Brilho/Opacidade & Brilhante & & \\
\hline
\end{tabular}

\begin{tabular}{|c|c|c|c|c|c|}
\hline \multicolumn{6}{|c|}{ Testes Preliminares e complementares } \\
\hline Catalase & Positivo & Hidrolise de Arginina & Negativo & $\begin{array}{l}\text { Voges } \\
\text { Proskauer }\end{array}$ & Positivo \\
\hline Oxidase & Negativo & Hidrolise de Lisina & Positivo & Arabinose & Positivo \\
\hline Indol & Negativo & Hidrolise de Ornitina & Negativo & Lactose & Positivo \\
\hline Redução de Nitrato & Positivo & Lecitinase & Negativo & Rhamnose & Positivo \\
\hline $\begin{array}{l}\text { Metabolismo } \\
\text { fermentativo e } \\
\text { oxidativo }\end{array}$ & $\begin{array}{l}\text { Oxidativo e } \\
\text { fermentativo }\end{array}$ & Manitol & Positivo & Sacarose & Positivo \\
\hline Citrato & Positivo & $\begin{array}{l}\text { Crescimento } \\
\text { Macconkey }\end{array}$ & Positivo & Sorbitol & Positivo \\
\hline Uréia & Positivo & Hidrólise gelatina & Negativo & Rafinose & Positivo \\
\hline
\end{tabular}


Coleção de Culturas Tropical www.cct.org.br

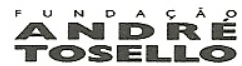

Fundação André Tosello www.fat.org.br

R. Latino Coelho, 1301 Pq. Taquaral CEP 13087-010 Campinas SP

Fone/Fax: (19) 3242-7022

Fax: (19) 3242-7827

CNPJ 46.126.322/0001-82

\begin{tabular}{|c|c|c|c|}
\hline \multicolumn{4}{|c|}{ Vitek } \\
\hline $\begin{array}{c}\text { DP3 - 2,4,4 - Tricol } 2 \text { - hidroxico } \\
\text { éter difenil }\end{array}$ & + & RAF - rafinose & + \\
\hline $\begin{array}{l}\text { OFG - Oxidação e/ou } \\
\text { ferementação glicose }\end{array}$ & + & SOR - sorbitol & + \\
\hline GC - Triptofano & + & SUC - sacarose & + \\
\hline ACE - Acetamina & - & INO - inositol & + \\
\hline ESC - esculina & + & ADO - adonitol & + \\
\hline PLI - indoxil -beta -D- glucosídeo & + & COU - p-coumarino & + \\
\hline URE - uréia & + & H2S - hidróxido de sulfito & - \\
\hline CIT - citrato & + & $\begin{array}{l}\text { ONPG - o-nitrofenil-beta-D- } \\
\text { galactopiranosídeo }\end{array}$ & + \\
\hline MAL - malonato & + & RHA - ramnose & + \\
\hline TDA - Triptofano & - & ARA - L-arabinose & + \\
\hline PXB - Polimixina B & - & GLU - glicose fermentação & + \\
\hline LAC/TLA - lactose & + & ARG - arginina & - \\
\hline MLT - maltose & + & LYS - lisina & +- \\
\hline MAN - manitol & + & ORN - ornitina & - \\
\hline XYL-xilose & + & Oxi - oidase & - \\
\hline
\end{tabular}

\section{Resultado da identificação}

Identificação foi realizada com testes bioquímicos, sistema de identificação Vitek (porcentagem de identificação de 99\%) e comparação com a literatura, resultando: Klebsiella pneumoniae. 
Coleção de Culturas Tropical www.cct.org.br
Fundação André Tosello www.fat.org.br

R. Latino Coelho, 1301 Pq. Taquara CEP 13087-010 Campinas SP

Fone/Fax: (19) 3242-7022

Fax: (19) 3242-7827

CNPJ 46.126.322/0001-82

\begin{tabular}{|c|c|}
\hline Meio de cultura & NA \\
\hline Temperatura & $37^{\circ} \mathrm{C}$ \\
\hline
\end{tabular}

\begin{tabular}{|c|c|c|c|}
\hline \multicolumn{2}{|c|}{ Característica da Colônia } & Forma & Bastonete \\
\hline Cor & Transparente & Gram & Negativo \\
\hline Forma & Circular, plana & Rearranjo & Lado a lado \\
\hline Margem & Regular & Móveis & Negativo \\
\hline Superfície & Lisa & Requerimento de Oxigênio & Aeróbio \\
\hline Textura & Cremosa & & \\
\hline
\end{tabular}

\begin{tabular}{|c|c|c|c|}
\hline \multicolumn{2}{|c|}{ Testes preliminares e complementares } & Negativo \\
\hline Catalase & Positivo & Uréia & Negativo \\
\hline Oxidase & Negativo & Hidrolise de Arginina & Duvidoso \\
\hline $\begin{array}{c}\text { Redução de Nitrato } \\
\text { Metabolismo fermentativo e } \\
\text { oxidativo }\end{array}$ & Negativo & Crescimento em $\mathrm{MAC}$ & Positivo \\
\hline Gelatina & Negativo & Crescimento CN $7,5 \% \mathrm{NaCl}$ & Positivo \\
\hline Lecitinase & Negativo & Agar sangue & Alfa hem[olise \\
\hline Manitol & Negativo & Crescimento $\mathrm{CN}$ a $41^{\circ} \mathrm{C}$ & Positivo \\
\hline
\end{tabular}


Coleção de Culturas Tropical www.cct.org.br

\begin{tabular}{|c|c|c|c|}
\hline \multicolumn{4}{|c|}{ Vitek } \\
\hline $\begin{array}{c}\text { DP3 - 2,4,4-Tricol } 2 \text { - hidroxico éter } \\
\text { difenil }\end{array}$ & - & RAF - rafinose & - \\
\hline $\begin{array}{c}\text { OFG - Oxidação e/ou ferementação } \\
\text { glicose }\end{array}$ & - & SOR - sorbitol & - \\
\hline GC - Triptofano & - & SUC - sacarose & - \\
\hline ACE - Acetamina & - & INO - inositol & - \\
\hline ESC - esculina & - & ADO - adonitol & - \\
\hline PLI - indoxil -beta -D- glucosídeo & - & COU - p- coumarino & - \\
\hline URE - uréia & - & H2S - hidróxido de sulfito & - \\
\hline CIT - citrato & - & $\begin{array}{l}\text { ONPG - o-nitrofenil-beta-D- } \\
\text { galactopiranosideo }\end{array}$ & - \\
\hline MAL - malonato & + & RHA - ramnose & - \\
\hline TDA - Triptofano & - & ARA - L-arabinose & - \\
\hline PXB - Polimixina B & - & GLU - glicose fermentação & - \\
\hline LAC/TLA - lactose & - & $\mathrm{ARG}$ - arginina & - \\
\hline MLT - maltose & - & LYS - lisina & - \\
\hline MAN - manitol & - & ORN - ornitina & - \\
\hline XYL-xilose & - & OXI - oxidase & - \\
\hline
\end{tabular}

\section{Resultado da identificação}

Identificação foi realizada com testes bioquímicos, sistema de identificação Vitek (porcentagem de identificação de 97\%) e comparação com a literatura, resultando: Acinet́obacter juniii. 
Coleção de Culturas Tropical www.cct.org.br
Fundação André Tosello

www.fat.org.br

R. Latino Coelho, $1301 \mathrm{Pq}$. Taquaral

CEP 13087-010 Campinas SP

Fone/Fax: (19) 3242-7022

Fax: (19) 3242-7827

CNPJ 46.126.322/0001-82

FICHA DE IDENTIFICAÇÃO

No. SERVIÇO: B 090032-3

\begin{tabular}{|c|c|}
\hline Meio de cultura & NA \\
\hline Temperatura & $37^{\circ} \mathrm{C}$ \\
\hline
\end{tabular}

\begin{tabular}{|c|c|c|c|}
\hline \multicolumn{2}{|c|}{ Característica da Colônia } & \multicolumn{2}{c|}{ Característica da Célula } \\
\hline Cor & Amarela & Forma & Cocos \\
\hline Forma & Plana & Gram & Positivo \\
\hline Margem & Irregular & Rearranjo & Tétrade \\
\hline Superfície & Lisa & Móveis & Negativo \\
\hline Textura & Cremosa & Requerimento de Oxigênio & Anaeróbio facultativo \\
\hline Brilho/Opacidade & Opaca & & \\
\hline
\end{tabular}

\begin{tabular}{|c|c|c|c|}
\hline \multirow{2}{*}{ Catalase } & Positivo & Citrato & Negativo \\
\hline Oxidase & Negativo & Uréia & Negativo \\
\hline Indol & Positivo & $\begin{array}{c}\text { Hidrolise de } \\
\text { Arginina }\end{array}$ & Positivo \\
\hline Redução de Nitrato & Negativo & $\begin{array}{c}\text { Hidrolise de Lisina } \\
\text { Positivo }\end{array}$ & Negativo \\
\hline Hidrólise gelatina & Positivo & Hidrolise de Ornitina & Negativo \\
\hline $\begin{array}{c}\text { Crescimento CN 7,5\% } \\
\text { NaCl }\end{array}$ & Positivo & $\begin{array}{c}\text { Hidrólise de } \\
\text { Esculina }\end{array}$ & Positivo \\
\hline Beta hemólise & Positivo & Sacarose & \\
\hline
\end{tabular}


Coleção de Culturas Tropical www.cct.org.br
Fundação André Tosello

www.fat.org.br

R. Latino Coelho, 1301 Pq. Taquaral

CEP 13087-010 Campinas SP

Fone/Fax: (19) 3242-7022

Fax: (19) 3242-7827

CNPJ 46.126.322/0001-82

\begin{tabular}{|c|c|c|c|}
\hline \multicolumn{4}{|c|}{ BBL } \\
\hline $\begin{array}{l}\text { FCT - controle negativo } \\
\text { fluorescente }\end{array}$ & - & MNT - manitol & - \\
\hline FPH - fenilalanina & + & GLR - glicerol & - \\
\hline FTR - triptofano & + & $\begin{array}{l}\text { PCE - nitrofenil- } \beta-D- \\
\text { celibiosideo }\end{array}$ & - \\
\hline $\mathrm{FHO}$ - fosfato & + & $\begin{array}{l}\text { PAM - nitrofenil- } \alpha \text {-D- } \\
\text { maltosideo }\end{array}$ & - \\
\hline TRE - trealose & - & ESC - esculina & - \\
\hline SUC - sacarose & + & FVA - L-valina & D \\
\hline ARA - arabinose & - & FPY - L-acido piroglutâmico & + \\
\hline BGL - nitrofenil- $\beta$-D-glicoside & - & FGA - 4MU- $\beta$-D-glucosaminida & - \\
\hline $\mathrm{PHO}$ - nitrofenil fosfato & - & FIS - isoleucina & - \\
\hline URE - Ureia & + & MAB - metil $\alpha \& \beta$ glicosideo & - \\
\hline FGC - 4MU- $\beta$-D-glucosideo & - & MTT - maltotriose & - \\
\hline FGS4MU- $\alpha$-D-glucosideo & D & FRU - frutose & - \\
\hline FAR - L - arginina & D & PLN - prolina \& leucina & + \\
\hline $\begin{array}{l}\text { FGN - } 4 M U-\beta-D- \\
\text { glucuronideo }\end{array}$ & - & PGO - ONPG & - \\
\hline LAC - lactose & - & ARG - arginina & + \\
\hline
\end{tabular}

\section{Resultado da identificação}

Identificação foi realizada com testes bioquímicos, sistema de identificação BBL CRYSTAL (porcentagem de identificação de 99,75\%) e comparação com a literatura, resultando: Micrococcus Iuteus. 
Coleção de Culturas Tropical www.cct.org.br

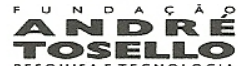

Fundação André Tosello www.fat.org.br

R. Latino Coelho, 1301 Pq. Taquaral

CEP 13087-010 Campinas SP

Fone/Fax: (19) 3242-7022

Fax: (19) 3242-7827

CNP] 46.126.322/0001-82

\begin{tabular}{|l|l|}
\hline FICHA DE IDENTIFICAÇÃO & No. SERVIÇO: B 090032-4 \\
\hline
\end{tabular}

\begin{tabular}{|c|c|}
\hline Meio de cultura & NA \\
\hline Temperatura & $37^{\circ} \mathrm{C}$ \\
\hline
\end{tabular}

\begin{tabular}{|c|c|c|c|}
\hline \multicolumn{2}{|c|}{ Característica da Colônia } & Forma & Coracterística da Célula \\
\hline Cor & Amarela & Gram & Positivo \\
\hline Forma & Circular & Rearranjo & Tétrade \\
\hline Margem & Regular & Móveis & Negativo \\
\hline Superficie & Lisa & Requerimento de Oxigênio & Anaeróbio facultativo \\
\hline Textura & Cremosa & & \\
\hline
\end{tabular}

\begin{tabular}{|c|c|c|c|c|c|}
\hline \multicolumn{2}{|c|}{ Testes Preliminares } & Negativo & Beta-Hemolise \\
\hline Catalase & Positivo & Uréia & Positivo & Negativo \\
\hline Oxidase & Negativo & Hidrolise de Arginina & Positivo & Sacarose & Positivo \\
\hline Indol & Negativo & Manitol & Negativo & Galactose \\
\hline Redução de Nitrato & Positivo & Esculina & Negativo & $\begin{array}{c}\text { Crescimento } \mathrm{CN} 10 \% \\
\mathrm{NaCl}\end{array}$ & $\begin{array}{c}\text { Crescimento a } \\
45^{\circ} \mathrm{C}\end{array}$ \\
\hline Crescimento a $45^{\circ} \mathrm{C}$ & Positivo & Lecitinase & & & \\
\hline
\end{tabular}


Coleção de Culturas Tropical www.cct.org.br
Fundação André Tosello www.fat.org.br

R. Latino Coelho, 1301 Pq. Taquaral CEP 13087-010 Campinas SP Fone/Fax: (19) 3242-7022

Fax: (19) 3242-7827

CNPJ 46.126.322/0001-82

\begin{tabular}{|c|l|c|l|}
\hline \multicolumn{5}{|c|}{ Vitek } \\
\hline PB - base peptona & + & RAF - rafinose & - \\
\hline BAC - bacitracina & - & SAL - salicina & - \\
\hline OPT - optoquina & + & SOR - sorbitol & - \\
\hline HCS - hemicelulose & + & SUC - sacarose & + \\
\hline 6NC - cloreto de sódio 6\% & + & TRE - trealose & - \\
\hline 10B - 10\% de bile & + & ARA - arabinose & - \\
\hline $40 B-40 \%$ de bile & + & PYR - piruvato & - \\
\hline ESC - esculina & - & PUL - pululana & - \\
\hline ARG - arginina & + & INU - inulina & - \\
\hline URE - ureia & - & MEL - melibiose & - \\
\hline TZR - vermelho de & + & MLZ - melizitose & - \\
\hline tetrazólio & & & + \\
\hline NOV - novabiocina & - & CEL - celobiose & - \\
\hline DEX - dextrose & + & RIB - ribose & + \\
\hline LAC - lactose & - & XYL - xilose & - \\
\hline MAN - manitol & + & CAT- catalase & + \\
\hline
\end{tabular}

\section{Resultado da identificação}

Identificação foi realizada com testes bioquímicos, sistema de identificação Vitek (porcentagem de identificação de 97\%) e comparação com a literatura, resultando: Staphylococcus aureus 
Coleção de Culturas Tropical www.cct.org.br

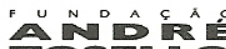

Fundação André Tosello

www.fat.org.br

R. Latino Coelho, 1301 Pq. Taquaral

CEP 13087-010 Campinas SP

Fone/Fax: (19) 3242-7022

Fax: (19) 3242-7827

CNPJ 46.126.322/0001-82
FICHA DE IDENTIFICAÇÃO

No. SERVIÇO: B 090032-5

\begin{tabular}{|c|c|}
\hline Meio de cultura & NA \\
\hline Temperatura & $37^{\circ} \mathrm{C}$ \\
\hline
\end{tabular}

\begin{tabular}{|c|c|c|c|}
\hline \multicolumn{2}{|c|}{ Característica da Colônia } & \multicolumn{2}{c|}{ Caracteristica da Célula } \\
\hline Cor & Amarela & Forma & Cocos \\
\hline Forma & Circular, plana & Rearranjo & Tétrade \\
\hline Margem & Regular & Móveis & Negativo \\
\hline Superfície & Lisa & Requerimento de Oxigênio & Anaeróbio facultativo \\
\hline Textura & Cremosa & & \\
\hline
\end{tabular}

\begin{tabular}{|c|c|c|c|c|c|}
\hline \multicolumn{5}{|c|}{ Testes Preliminares } \\
\hline Catalase & Positivo & Uréia & Duvidoso & Beta-Hemolise \\
\hline Oxidase & Positivo & Hidrolise de Arginina & Positivo & Xilose & Negativo \\
\hline Indol & Negativo & Manitol & Positivo & Sacarose & Positivo \\
\hline Redução de Nitrato & Positivo & Esculina & Negativo & Galactose & Positivo \\
\hline Crescimento a $45^{\circ} \mathrm{C}$ & Positivo & Lecitinase & Negativo & $\begin{array}{c}\text { Crescimento CN } 10 \% \\
\text { NaCl }\end{array}$ \\
\hline
\end{tabular}


Coleção de Culturas Tropical www.cct.org.br

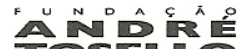

rosents
Fundação André Tosello www.fat.org.br

R. Latino Coelho, 1301 Pq. Taquaral CEP 13087-010 Campinas SP

Fone/Fax: (19) 3242-7022

Fax: (19) 3242-7827

CNPJ 46.126.322/0001-82

\begin{tabular}{|c|l|c|l|}
\hline \multicolumn{5}{|c|}{ Vitek } \\
\hline PB - base peptona & + & RAF - rafinose & - \\
\hline BAC - bacitracina & - & SAL - salicina & - \\
\hline OPT - optoquina & + & SOR - sorbitol & - \\
\hline HCS - hemicelulose & + & SUC - sacarose & + \\
\hline 6NC - cloreto de sódio 6\% & + & TRE - trealose & - \\
\hline 10B - 10\% de bile & + & ARA - arabinose & - \\
\hline $40 B-40 \%$ de bile & + & PYR - piruvato & - \\
\hline ESC - esculina & - & PUL - pululana & - \\
\hline ARG - arginina & + & INU - inulina & - \\
\hline URE - ureia & - & MEL - melibiose & - \\
\hline TZR - vermelho de & + & MLZ - melizitose & - \\
\hline tetrazólio & & & + \\
\hline NOV - novabiocina & - & CEL - celobiose & - \\
\hline DEX - dextrose & + & RIB - ribose & + \\
\hline LAC - lactose & - & XYL - xilose & - \\
\hline MAN - manitol & + & CAT- catalase & + \\
\hline
\end{tabular}

\section{Resultado da identificação}

Identificação foi realizada com testes bioquímicos, sistema de identificação Vitek (porcentagem de identificação de 97\%) e comparação com a literatura, resultando: Staphylococcus aureus 
Coleção de Culturas Tropical www.cct.org.br
Fundação André Tosello www.fat.org.br

R. Latino Coelho, 1301 Pq. Taquaral

CEP 13087-010 Campinas SP

Fone/Fax: (19) 3242-7022

Fax: (19) 3242-7827

CNP] 46.126.322/0001-82

\begin{tabular}{|c|c|}
\hline Meio de cultura & NA \\
\hline Temperatura & $37^{\circ} \mathrm{C}$ \\
\hline
\end{tabular}

\begin{tabular}{|c|c|c|c|}
\hline \multicolumn{2}{|c|}{ Característica da Colônia } & \multicolumn{2}{c|}{ Característica da Célula } \\
\hline Cor & Amarela & Forma & Cocos \\
\hline Forma & Circular, plana & Gram & Tétrade \\
\hline Margem & Regular & Rearranjo & Negativo \\
\hline Superfície & Lisa & Requerimento de Oxigênio & Anaeróbio facultativo \\
\hline Textura & Cremosa & & \\
\hline
\end{tabular}

\begin{tabular}{|c|c|c|c|c|c|}
\hline \multicolumn{2}{|c|}{ Testes Preliminares } \\
\hline Catalase & Positivo & Uréia & Duvidoso & Beta-Hemolise \\
\hline Oxidase & Positivo & Hidrolise de Arginina & Positivo & Xilose & Negativo \\
\hline Indol & Negativo & Manitol & Positivo & Sacarose & Positivo \\
\hline Redução de Nitrato & Positivo & Esculina & Negativo & Galactose & Positivo \\
\hline Crescimento a 45ㄷ & Positivo & Lecitinase & Negativo & $\begin{array}{c}\text { Crescimento CN } 10 \% \\
\text { NaCl }\end{array}$ \\
\hline
\end{tabular}


Coleção de Culturas Tropical www.cct.org.br
Fundação André Tosello www.fat.org.br

R. Latino Coelho, 1301 Pq. Taquaral CEP 13087-010 Campinas SP Fone/Fax: (19) 3242-7022

Fax: (19) 3242-7827

CNPJ 46.126.322/0001-82

\begin{tabular}{|c|c|c|c|}
\hline \multicolumn{4}{|c|}{ Vitek } \\
\hline PB - base peptona & + & RAF - rafinose & - \\
\hline BAC - bacitracina & - & SAL - salicina & - \\
\hline OPT - optoquina & + & SOR - sorbitol & - \\
\hline HCS - hemicelulose & + & SUC - sacarose & + \\
\hline $6 \mathrm{NC}$ - cloreto de sódio $6 \%$ & + & TRE - trealose & - \\
\hline $10 \mathrm{~B}-10 \%$ de bile & + & ARA - arabinose & - \\
\hline $40 \mathrm{~B}-40 \%$ de bile & + & PYR - piruvato & - \\
\hline ESC - esculina & - & PUL - pululana & - \\
\hline ARG - arginina & + & INU - inulina & - \\
\hline URE - ureia & - & MEL - melibiose & - \\
\hline $\begin{array}{c}\text { TZR - vermelho de } \\
\text { tetrazólio }\end{array}$ & + & MLZ - melizitose & - \\
\hline NOV - novabiocina & - & CEL - celobiose & - \\
\hline DEX - dextrose & + & RIB - ribose & + \\
\hline LAC - lactose & - & XYL - xilose & - \\
\hline MAN - manitol & + & CAT- catalase & + \\
\hline
\end{tabular}

\section{Resultado da identificação}

Identificação foi realizada com testes bioquímicos, sistema de identificação Vitek (porcentagem de identificação de 97\%) e comparação com a literatura, resultando: Staphylococcus aureus 
Coleção de Culturas Tropical www.cct.org.br
Fundação André Tosello www.fat.org.br

R. Latino Coelho, $1301 \mathrm{Pq}$. Taquaral

CEP 13087-010 Campinas SP

Fone/Fax: (19) 3242-7022

Fax: (19) 3242-7827

CNPJ 46.126.322/0001-82

FICHA DE IDENTIFICAÇÃO

No. SERVICCO: B 090032-7

\begin{tabular}{|c|c|}
\hline Meio de cultura & NA \\
\hline Temperatura & $37^{\circ} \mathrm{C}$ \\
\hline
\end{tabular}

\begin{tabular}{|c|c|c|c|}
\hline \multicolumn{2}{|c|}{ Característica da Colônia } & \multicolumn{2}{c|}{ Característica da Célula } \\
\hline Cor & Branca & Forma & Bastonete pequeno \\
\hline Forma & Elevada, circular & Gram & Negativo \\
\hline Margem & Regular & Rearranjo & Isolados e lado a lado \\
\hline Superfície & Lisa & Móveis & Negativo \\
\hline Textura & Cremosa & Requerimento de Oxigênio & Anaeróbio facultativo \\
\hline Brilho/Opacidade & Brilhante & & \\
\hline
\end{tabular}

\begin{tabular}{|c|c|c|c|c|c|}
\hline \multicolumn{6}{|c|}{ Testes Preliminares e complementares } \\
\hline Catalase & Positivo & Hidrolise de Arginina & Negativo & $\begin{array}{c}\text { Voges } \\
\text { Proskauer }\end{array}$ & Positivo \\
\hline Oxidase & Negativo & Hidrolise de Lisina & Positivo & Arabinose & Positivo \\
\hline Indol & Negativo & Hidrolise de Ornitina & Negativo & Lactose & Positivo \\
\hline Redução de Nitrato & Positivo & Lecitinase & Negativo & Rhamnose & Positivo \\
\hline $\begin{array}{l}\text { Metabolismo } \\
\text { fermentativo e } \\
\text { oxidativo }\end{array}$ & $\begin{array}{l}\text { Oxidativo e } \\
\text { fermentativo }\end{array}$ & Manitol & Positivo & Sacarose & Positivo \\
\hline Citrato & Positivo & $\begin{array}{l}\text { Crescimento } \\
\text { Macconkey }\end{array}$ & Positivo & Sorbitol & Positivo \\
\hline Uréia & Positivo & Hidrólise gelatina & Negativo & Rafinose & Positivo \\
\hline
\end{tabular}


Coleção de Culturas Tropical www.cct.org.br
Fundação André Tosello www.fat.org.br

R. Latino Coelho, 1301 Pq. Taquaral

CEP 13087-010 Campinas SP

Fone/Fax: (19) 3242-7022

Fax: (19) 3242-7827

CNPJ 46.126.322/0001-82

\begin{tabular}{|c|c|c|c|}
\hline \multicolumn{4}{|c|}{ Vitek } \\
\hline $\begin{array}{c}\text { DP3 - 2,4,4 - Tricol } 2 \text { - hidroxico } \\
\text { éter difenil }\end{array}$ & + & RAF - rafinose & + \\
\hline $\begin{array}{l}\text { OFG - Oxidação e/ou } \\
\text { ferementação glicose }\end{array}$ & + & SOR - sorbitol & + \\
\hline GC - Triptofano & + & SUC - sacarose & + \\
\hline ACE - Acetamina & - & INO - inositol & + \\
\hline ESC - esculina & + & ADO - adonitol & + \\
\hline PLI - indoxil -beta-D- glucosídeo & + & COU - p-coumarino & + \\
\hline URE - uréia & + & H2S - hidróxido de sulfito & - \\
\hline CIT - citrato & + & $\begin{array}{c}\text { ONPG - o-nitrofenil-beta-D- } \\
\text { galactopiranosideo }\end{array}$ & + \\
\hline MAL - malonato & + & RHA - ramnose & + \\
\hline TDA - Triptofano & - & ARA - L-arabinose & + \\
\hline PXB - Polimixina B & - & GLU - glicose fermentação & + \\
\hline LAC/TLA - lactose & + & ARG - arginina & - \\
\hline MLT - maltose & + & LYS - lisina & + \\
\hline MAN - manitol & + & ORN - ornitina & - \\
\hline$X Y L-x i l o s e$ & + & Oxi - oidase & - \\
\hline
\end{tabular}

\section{Resultado da identificação}

Identificação foi realizada com testes bioquímicos, sistema de identificação Vitek (porcentagem de identificação de $99 \%$ ) e comparação com a literatura, resultando: Klebsiella pneumoniae. 
Coleção de Culturas Tropical www.cct.org.br
Fundação André Tosello

www.fat.org.br

R. Latino Coelho, 1301 Pq. Taquaral

CEP 13087-010 Campinas SP

Fone/Fax: (19) 3242-7022

Fax: (19) $3242-7827$

CNP] 46.126.322/0001-82

\begin{tabular}{|c|c|}
\hline Meio de cultura & NA \\
\hline Temperatura & $37^{\circ} \mathrm{C}$ \\
\hline
\end{tabular}

\begin{tabular}{|c|c|c|c|}
\hline \multicolumn{2}{|c|}{ Característica da Colo̊nia } & \multicolumn{2}{c|}{ Característica da Célula } \\
\hline Cor & Branca & Forma & Bastonete pequeno \\
\hline Forma & Elevada, circular & Rearranjo & Isolados e lado a ladio \\
\hline Margem & Regular & Móveis & Negativo \\
\hline Superficie & Lisa & Requerimento de Oxigênio & Anaeróbio facultativo \\
\hline Textura & Cremosa & & \\
\hline Brilho/Opacidade & Brilhante & & \\
\hline
\end{tabular}

\begin{tabular}{|c|c|c|c|c|c|}
\hline \multicolumn{6}{|c|}{ Testes Preliminares e complementares } \\
\hline Catalase & Positivo & Hidrolise de Arginina & Negativo & $\begin{array}{l}\text { Voges } \\
\text { Proskauer }\end{array}$ & Positivo \\
\hline Oxidase & Negativo & Hidrolise de Lisina & Positivo & Arabinose & Positivo \\
\hline Indol & Negativo & Hidrolise de Ornitina & Negativo & Lactose & Positivo \\
\hline Reduçăo de Nitrato & Positivo & Lecitinase & Negativo & Rhamnose & Positivo \\
\hline $\begin{array}{l}\text { Metabolismo } \\
\text { fermentativo e } \\
\text { oxidativo }\end{array}$ & $\begin{array}{l}\text { Oxidativo e } \\
\text { fermentativo }\end{array}$ & Manitol & Positivo & Sacarose & Positivo \\
\hline Citrato & Positivo & $\begin{array}{l}\text { Crescimento } \\
\text { Macconkey }\end{array}$ & Positivo & Sorbitol & Positivo \\
\hline Uréia & Negativo & Hidrólise gelatina & Negativo & Rafinose & Positivo \\
\hline Coagulase & Positivo & & & & \\
\hline
\end{tabular}


Coleção de Culturas Tropical www.cct.org.br

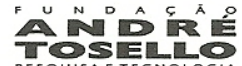

Fundação André Tosello www.fat.org.br

R. Latino Coelho, 1301 Pq. Taquaral CEP 13087-010 Campinas SP

Fone/Fax: (19) 3242-7022

Fax: (19) 3242-7827

CNPJ 46.126.322/0001-82

\begin{tabular}{|c|c|c|c|}
\hline \multicolumn{4}{|c|}{ Vitek } \\
\hline $\begin{array}{c}\text { DP3 - 2,4,4 - Tricol } 2 \text { - hidroxico } \\
\text { éter difenil }\end{array}$ & + & RAF - rafinose & + \\
\hline $\begin{array}{l}\text { OFG - Oxidação e/ou } \\
\text { ferementação glicose }\end{array}$ & + & SOR - sorbitol & + \\
\hline GC - Triptofano & + & SUC - sacarose & + \\
\hline ACE - Acetamina & - & INO - inositol & + \\
\hline ESC - esculina & + & ADO - adonitol & + \\
\hline PLI - indoxil -beta -D- glucosídeo & - & COU - p-coumarino & - \\
\hline URE - uréia & - & H2S - hidróxido de sulfito & - \\
\hline CIT - citrato & + & $\begin{array}{l}\text { ONPG - o-nitrofenil-beta-D- } \\
\text { galactopiranosídeo }\end{array}$ & - \\
\hline MAL - malonato & + & RHA - ramnose & + \\
\hline TDA - Triptofano & - & ARA - L-arabinose & + \\
\hline PXB - Polimixina B & - & GLU - glicose fermentação & + \\
\hline LAC/TLA - lactose & + & ARG - arginina & - \\
\hline MLT - maltose & + & LYS - lisina & + \\
\hline MAN - manitol & + & ORN - ornitina & - \\
\hline$X Y L-x i l o s e$ & + & Oxi - oidase & - \\
\hline
\end{tabular}

\section{Resultado da identificação}

Identificação foi realizada com testes bioquímicos, sistema de identificação Vitek (porcentagem de identificação de 99\%) e comparação com a literatura, resultando: Klebsiella pneumoniae. 